
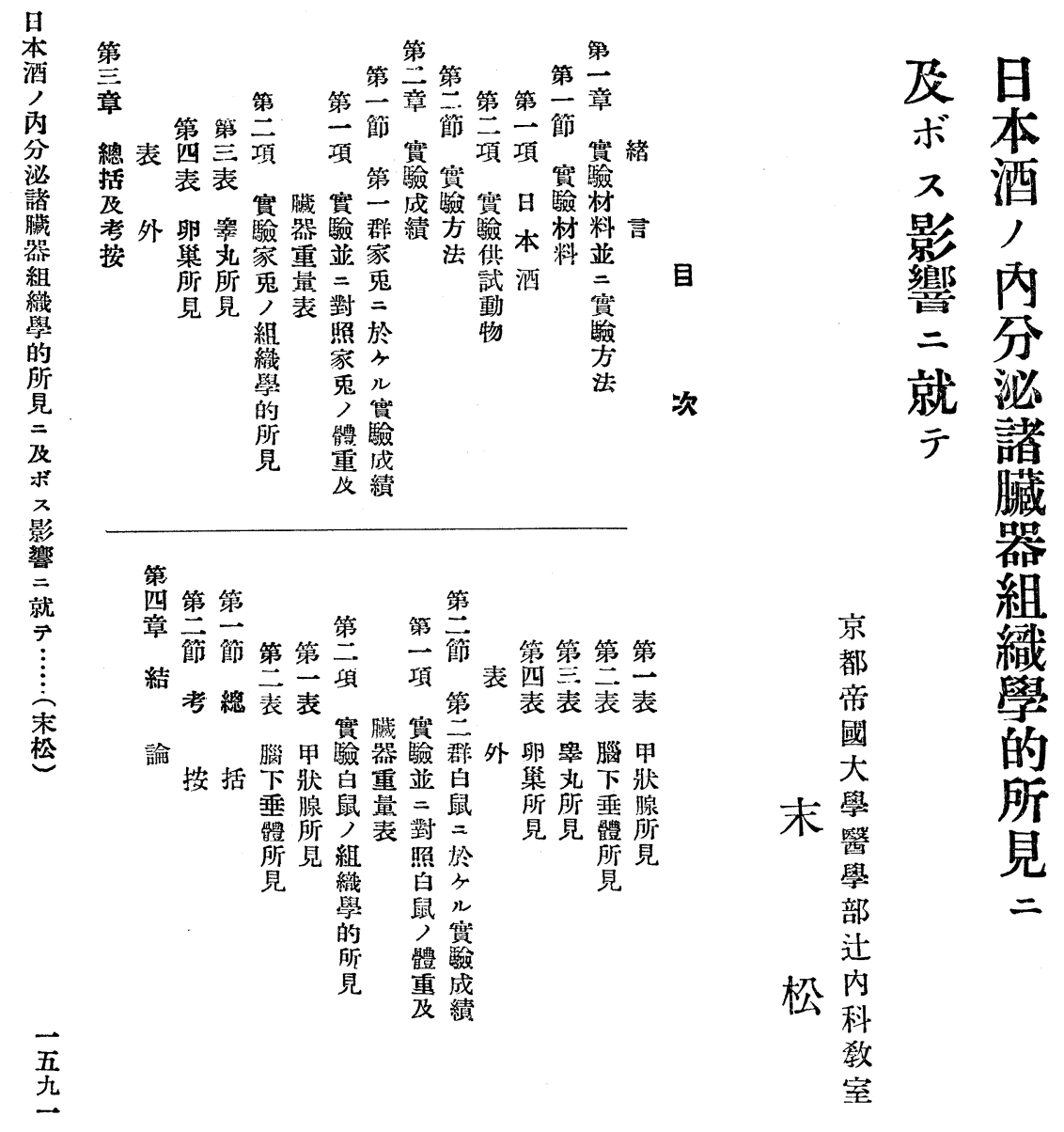

務

述 


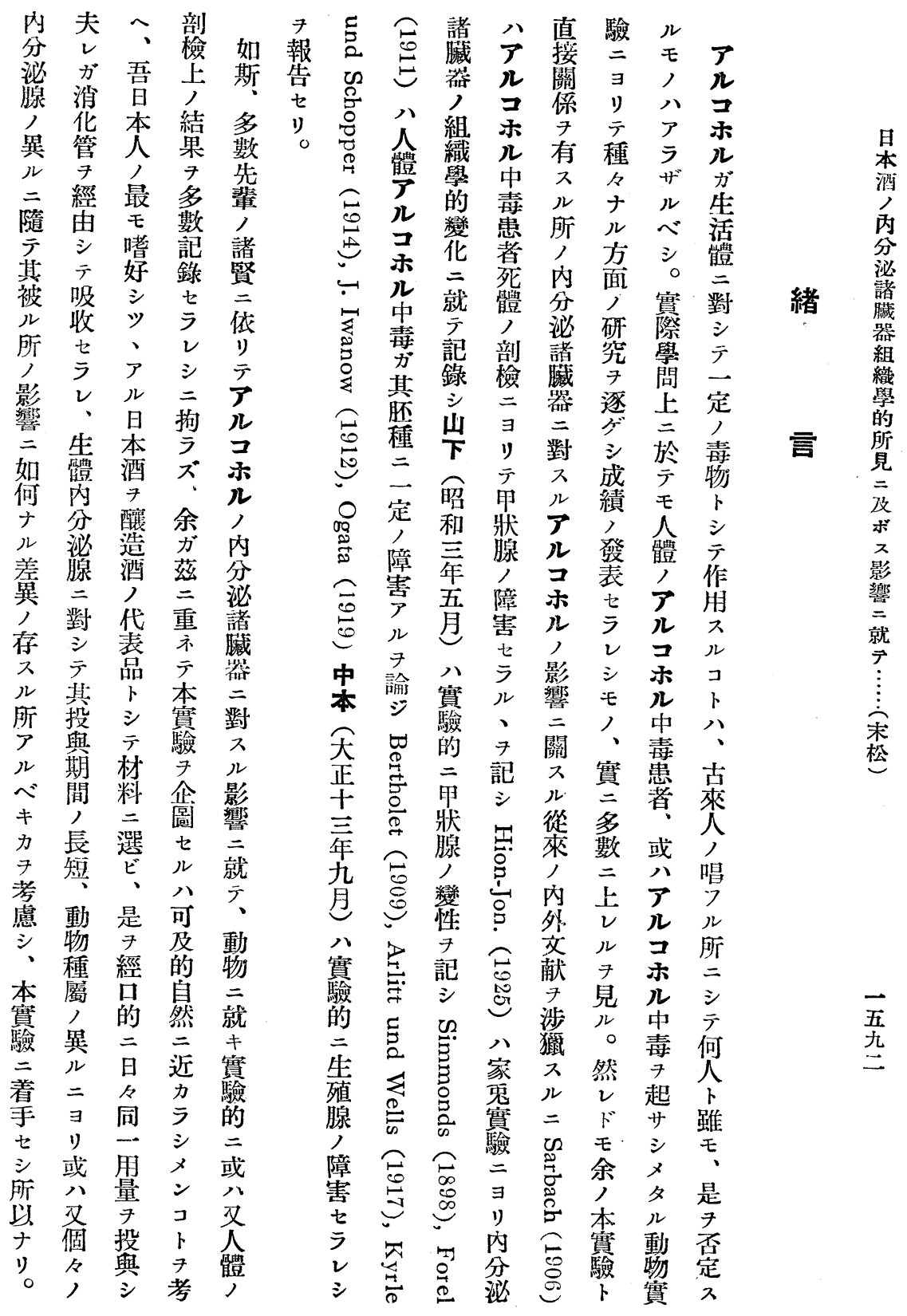




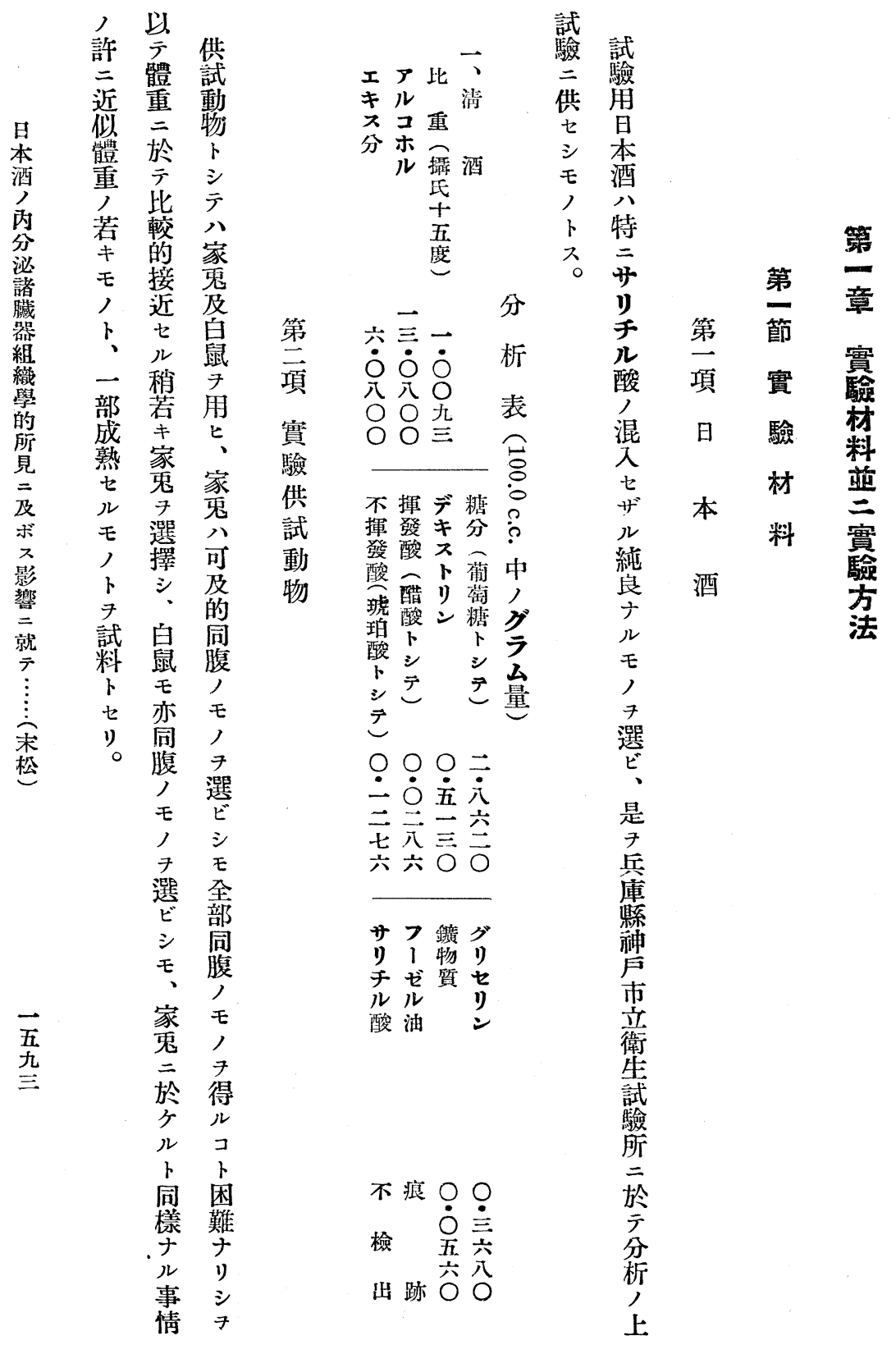




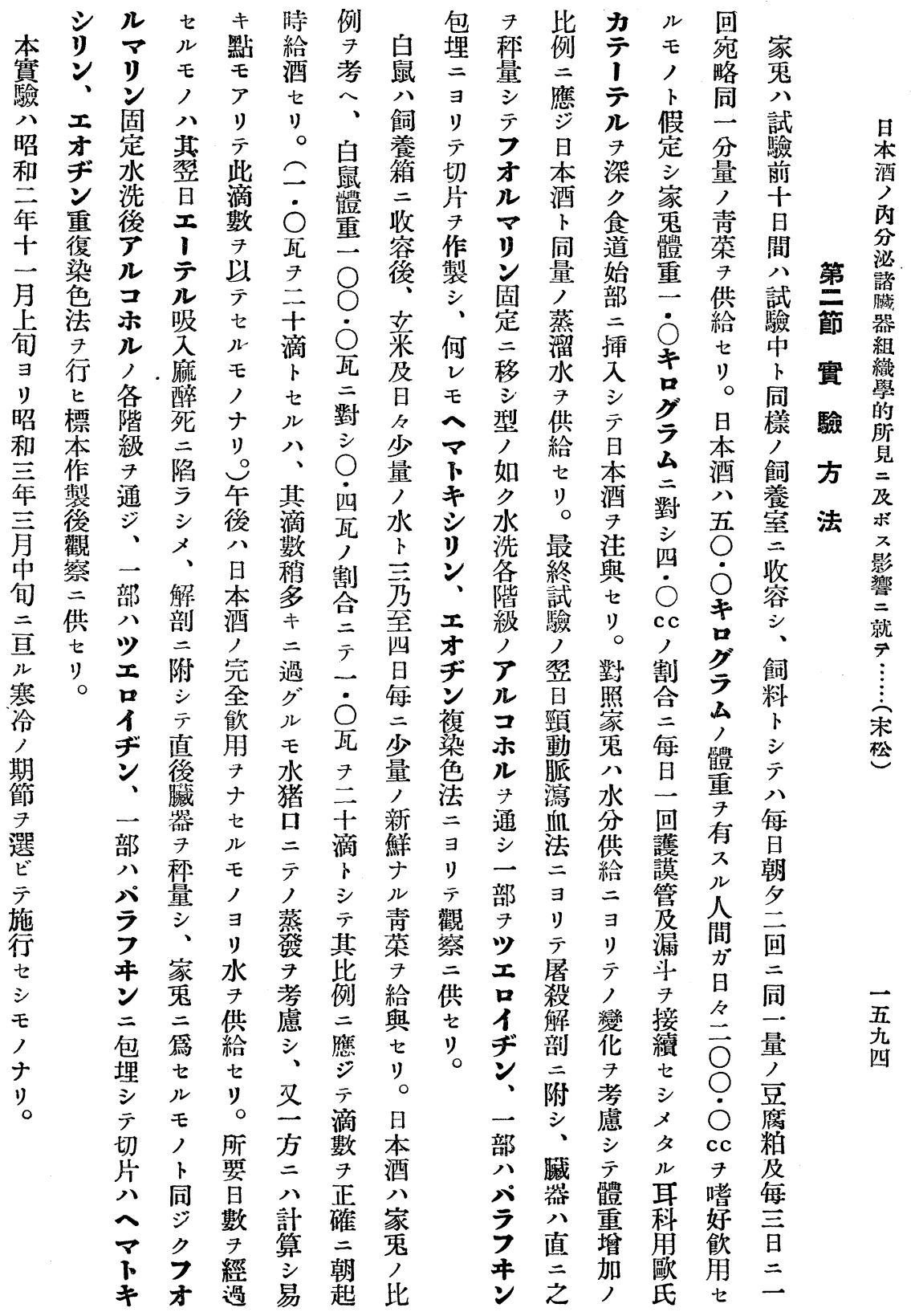




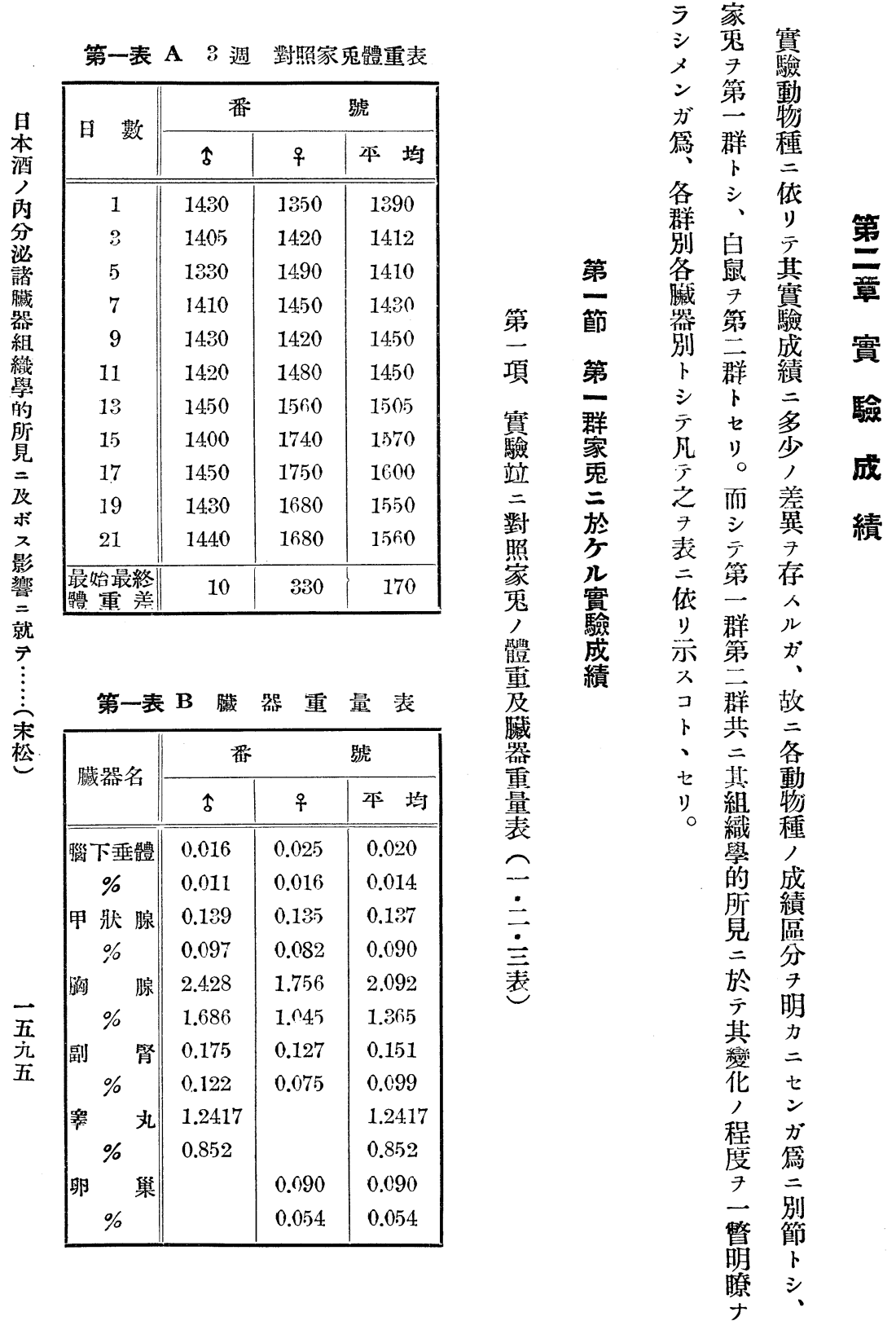


第一表 $\mathbf{G} 3$ 週 實驗家鬼體重表

\begin{tabular}{|c|c|c|c|c|c|c|}
\hline \multirow{2}{*}{ 日 數 } & \multicolumn{6}{|c|}{ 番 } \\
\hline & 1 우 & 2 우 & $3 \hat{8}$ & 4 占 & $5 \hat{~}$ & 平 均 \\
\hline 1 & 1135 & 1280 & 1330 & 1350 & 1180 & 1255 \\
\hline 8 & 1145 & 1260 & 1200 & 1380 & 1110 & 1219 \\
\hline 5 & 1230 & 1330 & 1180 & 1490 & 1180 & 1282 \\
\hline 7 & 1180 & 1310 & 1150 & 1450 & 1180 & 1254 \\
\hline 9 & 1170 & 3180 & 1280 & 1460 & 1220 & 1316 \\
\hline 11 & 1240 & 1380 & 1200 & 1400 & 1280 & 1300 \\
\hline 13 & 1210 & 1440 & 1270 & 1460 & 1410 & 1358 \\
\hline 15 & 1260 & $1460^{\prime}$ & 1310 & 1490 & 1310 & 1346 \\
\hline 17 & 1250 & 1450 & 1300 & 1480 & 1370 & 1262 \\
\hline 19 & 1250 & 1480 & 1430 & 1520 & 1410 & 1278 \\
\hline 21 & 1240 & 1480 & 1400 & 1520 & 1420 & $14: 12$ \\
\hline 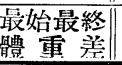 & 105 & 200 & 70 & 170 & 240 & 157 \\
\hline
\end{tabular}

第一表 D 睵 器 重 量 表

\begin{tabular}{|c|c|c|c|c|c|c|}
\hline \multirow{2}{*}{ 臟器名 } & \multicolumn{6}{|c|}{ 番 } \\
\hline & $1 \%$ & 2 우 & 3 今 & $4 \hat{\delta}$ & 5 占 & 本 均 \\
\hline 腦下乘體 & 0.016 & 0.017 & 0.020 & 0.018 & 0.016 & 0.019 \\
\hline$\%$ & 0.0129 & 0.0114 & 0.014 & 0.0118 & 0.0112 & 0.0129 \\
\hline 甲狀 腺 & 0.105 & 0.167 & 0.115 & 0.125 & 0.102 & 0.127 \\
\hline$\%$ & 0.0921 & 0.1128 & 0.0821 & 0.0822 & 0.0718 & 0.091 \\
\hline 胸㟫 & 0.760 & 1.840 & 1.622 & 1.361 & 2.760 & 1.669 \\
\hline$\%$ & 0.6666 & 1.2432 & 1.1585 & 0.8953 & 1.9436 & 1.197 \\
\hline 副 腎 & 0.129 & 0.111 & 0.112 & 0.090 & 0.104 & 0.109 \\
\hline$\%$ & 0.1014 & 0.0754 & 0.0802 & 0.0595 & 0.0732 & 0.078 \\
\hline 票 & & & 0.547 & 0.838 & 0.759 & 0.714 \\
\hline$\%$ & & & 0.8908 & 0.5182 & 0.5396 & 0.510 \\
\hline 卵 巢 & 0.026 & 0.057 & & & & 0.042 \\
\hline$\%$ & 0.0209 & 0.0388 & & & & 0.030 \\
\hline
\end{tabular}


第二表 A 5 週 惯驗家鬼體重表

\begin{tabular}{|c|c|c|c|c|c|c|}
\hline \multirow{2}{*}{ 日 數 } & \multicolumn{4}{|c|}{ 番 } & \multicolumn{2}{|c|}{ 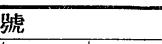 } \\
\hline & 1 우 & 2 ㅇ & 3 우 & 4 占 & 令 5 & 斗均 \\
\hline 1 & 1250 & 1380 & 885 & 1265 & 1500 & 1256 \\
\hline 3 & 1230 & 1830 & 1000 & 1330 & 1490 & 1256 \\
\hline 5 & 1380 & 1355 & 1050 & 1280 & 1480 & 1309 \\
\hline 7 & 1380 & 1390 & 1000 & 1230 & $14 \mathrm{~S} 0$ & 1298 \\
\hline 9 & 1410 & 1440 & 980 & 1300 & 1440 & 1314 \\
\hline 11 & 1380 & 1450 & 1000 & 1300 & 1410 & 1308 \\
\hline 13 & 1460 & 1480 & 1120 & 1460 & 1500 & 1404 \\
\hline 15 & 1460 & 1490 & 1230 & 1430 & 1500 & 1454 \\
\hline 17 & 1430 & 1560 & 1260 & 1430 & 1580 & 1452 \\
\hline 19 & 1470 & 1490 & 1280 & 1460 & 1670 & 1474 \\
\hline 21 & 1430 & 1600 & 1290 & 1460 & 1600 & 1476 \\
\hline 23 & 1550 & 1650 & 1410 & 1630 & 1760 & 1600 \\
\hline 25 & 1480 & 1680 & 1430 & 1610 & 1630 & 1546 \\
\hline 27 & 1500 & 1560 & 1480 & 1670 & 1630 & 1568 \\
\hline 29 & 1470 & 1580 & 1500 & 1680 & 1700 & 1576 \\
\hline 31 & 1530 & 1590 & 1560 & 1700 & 1730 & 1602 \\
\hline 33 & $14: 90$ & 1570 & 1560 & 1730 & 1730 & 1616 \\
\hline 35 & 1500 & 1590 & 1470 & 1780 & 1740 & 1616 \\
\hline $\begin{array}{l}\text { 最始最終 } \\
\text { 蹬重善 }\end{array}$ & 250 & 210 & 585 & 515 & 240 & 360 \\
\hline
\end{tabular}

第二表 $\mathbf{G}$ 枵藏 器 重 量 表

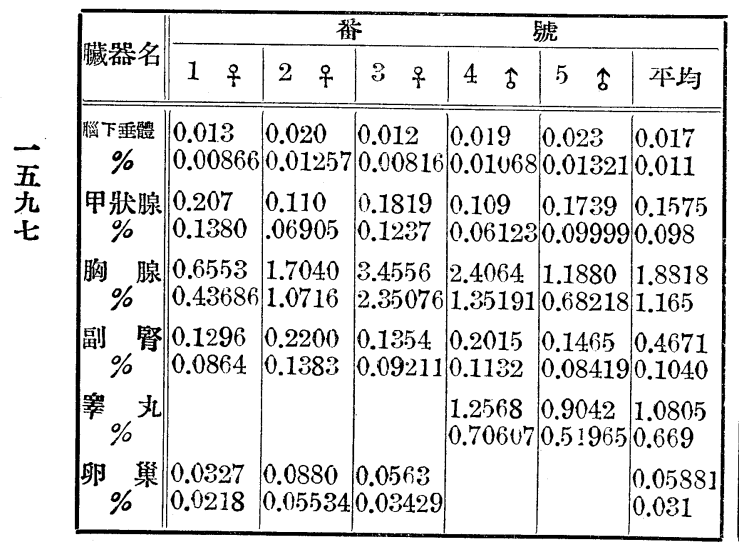

第二表 B 5 週對照家鬼體重表

\begin{tabular}{|c|c|c|c|}
\hline \multirow{2}{*}{ 日 數 } & \multicolumn{3}{|c|}{ 番 號 } \\
\hline & f & $q$ & 平均 \\
\hline 1 & 14.10 & 1345 & 1377 \\
\hline 3 & 1480 & 1430 & 1455 \\
\hline 5 & 1430 & 1400 & 1415 \\
\hline 7 & 1410 & $13 \pm 0$ & 1375 \\
\hline 9 & 1330 & 1440 & 1362 \\
\hline 11 & 1390 & 1390 & 1890 \\
\hline 13 & 14.50 & 1420 & 14355 \\
\hline 15 & 1490 & $14: 30$ & 1460 \\
\hline 17 & 1370 & 1460 & 1415 \\
\hline 19 & 1480 & 1460 & 1470 \\
\hline 21 & 1400 & 1630 & 1415 \\
\hline 23 & 1530 & 1610 & 1570 \\
\hline 25 & 1570 & 1620 & 1595 \\
\hline 27 & 1560 & 1640 & 1600 \\
\hline 29 & 1600 & 1620 & 1610 \\
\hline 31 & 1580 & 1680 & 1630 \\
\hline 33 & 1620 & 1650 & 1635 \\
\hline 35 & 1610 & 1710 & 1660 \\
\hline 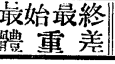 & 200 & 365 & 28 \\
\hline
\end{tabular}

第二表 D 呺藏器重 量 表

\begin{tabular}{|c|c|c|c|}
\hline \multirow{2}{*}{ 瀻器名 } & \multicolumn{3}{|c|}{ 番 號 } \\
\hline & 占 & ㅇ & 本均 \\
\hline 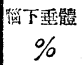 & $\mid \begin{array}{l}0.014 \\
0.0087\end{array}$ & $\mid \begin{array}{l}0.020 \\
0.0117\end{array}$ & $\mid \begin{array}{l}0.017 \\
0.0102\end{array}$ \\
\hline $\begin{array}{c}\text { 甲奘腺 } \\
\%\end{array}$ & $\mid \begin{array}{l}0.086 \\
0.053\end{array}$ & $\begin{array}{l}0.148 \\
0.087\end{array}$ & $\begin{array}{l}0.117 \\
0.071\end{array}$ \\
\hline 胸 $\%$ & $\begin{array}{l}1.7869 \\
1.111\end{array}$ & $\begin{array}{l}1.700 \\
0.994\end{array}$ & \begin{tabular}{|l}
1.7434 \\
1.050
\end{tabular} \\
\hline 副 \% & 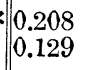 & $\begin{array}{l}0.213 \\
0.124\end{array}$ & $\begin{array}{l}0.2105 \\
0.127\end{array}$ \\
\hline 罢 $\%$ & $\begin{array}{l}1.4589 \\
0.879\end{array}$ & & $\begin{array}{l}1.4589 \\
0.879\end{array}$ \\
\hline |卵％巢 & & $\mid \begin{array}{l}0.098 \\
0.0573\end{array}$ & $\begin{array}{l}0.098 \\
0.0573\end{array}$ \\
\hline
\end{tabular}


第三表 A 7 週 實驗家鬼體重表

\begin{tabular}{|c|c|c|c|c|c|c|}
\hline \multirow{2}{*}{ 日 數 } & \multicolumn{4}{|c|}{ 番 } & \multicolumn{2}{|c|}{ 號 } \\
\hline & $1+9$ & 2 우 & 3 今 & 4 古 & 5 今 & 平均 \\
\hline 1 & 1280 & 1285 & 1075 & 980 & 1485 & 1228 \\
\hline 3 & 1340 & 1330 & 1040 & 1000 & 1460 & 1234 \\
\hline 5 & 1400 & 1430 & 1080 & 950 & 1520 & 1276 \\
\hline 7 & 1340 & 1350 & 980 & 1000 & 1480 & 1230 \\
\hline 9 & 1450 & 1380 & 980 & 1040 & 1490 & 1268 \\
\hline 11 & 1460 & 1430 & 940 & 1100 & 1600 & 1306 \\
\hline 13 & 1410 & 1490 & 1050 & 1190 & 1480 & 1354 \\
\hline 15 & 1260 & 1400 & 1060 & 1130 & 1530 & 1296 \\
\hline 17 & 1310 & 1400 & 1020 & 1100 & 1490 & 1264 \\
\hline 19 & 1380 & 1460 & 1030 & 1280 & 1430 & 1356 \\
\hline 21 & 1390 & 1490 & 1030 & 1210 & 1670 & 1358 \\
\hline 23 & 1430 & 1570 & 1130 & 1300 & 1680 & 1422 \\
\hline 25 & 1450 & 1520 & 1150 & 1370 & 1680 & 1434 \\
\hline 27 & 1480 & 1640 & 1200 & 1410 & 1700 & 1486 \\
\hline 29 & 1430 & 1560 & 1370 & 1380 & 1740 & 1506 \\
\hline 31 & 1450 & 1600 & 1230 & 1400 & 1740 & 1480 \\
\hline 33 & $14 / 0$ & 1670 & 1220 & 1480 & 1750 & 1518 \\
\hline 35 & 1495 & 1645 & 1235 & 1430 & 1880 & 1537 \\
\hline 37 & 140 & 1800 & 1235 & 1430 & 1960 & 1573 \\
\hline 39 & 1490 & 1830 & 1230 & 1490 & 1980 & $160 t$ \\
\hline 41 & 1480 & 1730 & 1330 & $15^{30}$ & 1980 & 1614 \\
\hline 43 & 1430 & 1730 & 1300 & 1580 & 2090 & 1626 \\
\hline 45 & 1460 & 1830 & 1320 & 1570 & 2000 & 1656 \\
\hline 47 & 1560 & 1750 & 1335 & 1670 & 2090 & 1680 \\
\hline 49 & 1560 & 1740 & 1230 & 1730 & 2080 & 1688 \\
\hline $\begin{array}{l}\text { 最始最終 } \\
\text { 體董 差 }\end{array}$ & 280 & 455 & 255 & 750 & 595 & 465 \\
\hline
\end{tabular}

第三表 $\mathbf{G}$ 臟 器 重 量 表

\begin{tabular}{|c|c|c|c|c|c|c|}
\hline \multirow{2}{*}{ 臓器名 } & \multicolumn{4}{|c|}{ 番 } & \multicolumn{2}{|l|}{ 號 } \\
\hline & 1 우 & 2 q & 3 占 & 4 今 & 5 今 & 平均 \\
\hline & $\begin{array}{l}0.013 \\
0.00833\end{array}$ & $\begin{array}{l}0.017 \\
0.00977\end{array}$ & 0.016 & 0.011 & $\begin{array}{l}0.015 \\
0.00721\end{array}$ & .0144 \\
\hline 甲只 & $\begin{array}{l}0.111 \\
0.0712\end{array}$ & $\begin{array}{l}0.137 \\
0.078\end{array}$ & $\begin{array}{l}0.105 \\
0.078\end{array}$ & $\begin{array}{l}0.182 \\
0.105\end{array}$ & $\begin{array}{l}0.164 \\
0.079\end{array}$ & $\begin{array}{l}0.129 \\
0.0823\end{array}$ \\
\hline${ }^{\circ}{ }^{\text {肳 }}$ & $\begin{array}{l}1.200 \\
0.7697\end{array}$ & $\begin{array}{l}1.2248 \\
0.6997\end{array}$ & $\begin{array}{l}1.1559 \\
0.86906\end{array}$ & 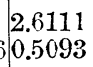 & $\begin{array}{l}3.0250 \\
1.4543\end{array}$ & $\begin{array}{l}1.9423 \\
1.15124\end{array}$ \\
\hline 副 $\%$ & $\begin{array}{l}0.1055 \\
0.0676\end{array}$ & $\begin{array}{l}0.12304 \\
0.07068\end{array}$ & 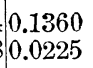 & $\begin{array}{l}0.1750 \\
0.1011\end{array}$ & $\begin{array}{l}0.1660 \\
0.07985\end{array}$ & $\begin{array}{l}0.1411 \\
0.08359\end{array}$ \\
\hline${ }_{\%}^{\prime}$ 丸九 & & & $\begin{array}{l}1.5820 \\
1.190\end{array}$ & $\begin{array}{l}0.9411 \\
0.5439\end{array}$ & $\begin{array}{l}1.4765 \\
0.710\end{array}$ & $\begin{array}{l}1.3332 \\
0.6200\end{array}$ \\
\hline 卵 $\%$ & $\left\{\begin{array}{l}0.0670 \\
0.0429\end{array}\right.$ & $5 \mid \begin{array}{l}0.0795 \\
0.04568\end{array}$ & & & & $\left|\begin{array}{l}0.0730 \\
0.04325\end{array}\right|$ \\
\hline
\end{tabular}

第三表 B 7 週 跬照家鬼體重表

\begin{tabular}{|c|c|c|c|}
\hline \multirow{2}{*}{ 日 數 } & \multicolumn{3}{|c|}{ 番 號 } \\
\hline & 占 & q & 平均 \\
\hline 1 & 1430 & 1350 & 1390 \\
\hline 3 & 1415 & 1330 & 1372 \\
\hline 5 & 1450 & 1480 & 1465 \\
\hline 7 & 1440 & 1420 & 1430 \\
\hline 9 & 1400 & 1390 & 1395 \\
\hline 11 & 1470 & 1440 & 1455 \\
\hline 13 & 1560 & 1510 & 1535 \\
\hline 15 & 1616 & 1550 & 1575 \\
\hline 17 & 1670 & 1600 & 1635 \\
\hline 19 & 1610 & 1650 & 1630 \\
\hline 21 & 1620 & 1630 & 1625 \\
\hline 23 & 1760 & 1800 & 1780 \\
\hline 25 & 1810 & 1850 & 1830 \\
\hline 27 & 1860 & 1900 & 1880 \\
\hline 29 & 1780 & 1860 & 1820 \\
\hline 31 & 1780 & 1930 & 1856 \\
\hline 33 & 1815 & 1930 & 1875 \\
\hline 35 & 1815 & 1930 & 1872 \\
\hline 37 & 1800 & 1900 & 1850 \\
\hline 39 & 1910 & 1970 & 1940 \\
\hline 41 & 1930 & 2030 & 1980 \\
\hline 43 & 1900 & 2050 & 1975 \\
\hline 45 & 1930 & 1930 & 1930 \\
\hline 47 & 2030 & 2080 & 2055 \\
\hline 49 & 2050 & 2080 & 2065 \\
\hline $\begin{array}{l}\text { 最始最終 } \\
\text { 體 重 羑 }\end{array}$ & 620 & $7: 30$ & 675 \\
\hline
\end{tabular}

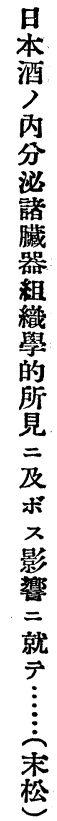

第三表 $\mathbf{D}$ 臟 器 重 量 表

\begin{tabular}{|c|c|c|c|}
\hline \multirow{2}{*}{$\begin{array}{l}\text { 藏器 } \\
\text { 名 }\end{array}$} & \multicolumn{3}{|c|}{$\begin{array}{ll}\text { 蕃 號 } \\
\end{array}$} \\
\hline & $\uparrow$ & 우 & 平均 \\
\hline 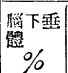 & $\left(\begin{array}{l}0.020 \\
0.00975\end{array}\right.$ & $\left|\begin{array}{l}0.014 \\
0.00673\end{array}\right|$ & $\mid \begin{array}{l}0.017 \\
0.00823\end{array}$ \\
\hline $\begin{array}{c}\text { 甲將腺 } \\
\%\end{array}$ & $\mid \begin{array}{l}0.154 \\
0.07512\end{array}$ & $2\left|\begin{array}{l}0.103 \\
0.04951\end{array}\right|$ & $\begin{array}{l}0.1280 \\
0.06198\end{array}$ \\
\hline
\end{tabular}

$\begin{array}{llll} & 2.271 & 1.720 & 1.995\end{array}$

\% 1.107800 .826920 .9661

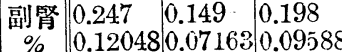

\begin{tabular}{|c|l|l|l|l}
$\%$ & 0.12048 & 0.07163 & 0.09588 \\
萦丸 & 1.410 & & 1.410 \\
$\%$ & 0.6878 & & 0.68287 \\
卵巢 & & 0.110 & 0.110 \\
$\%$ & & 0.05288 & 0.053268 \\
\hline
\end{tabular}




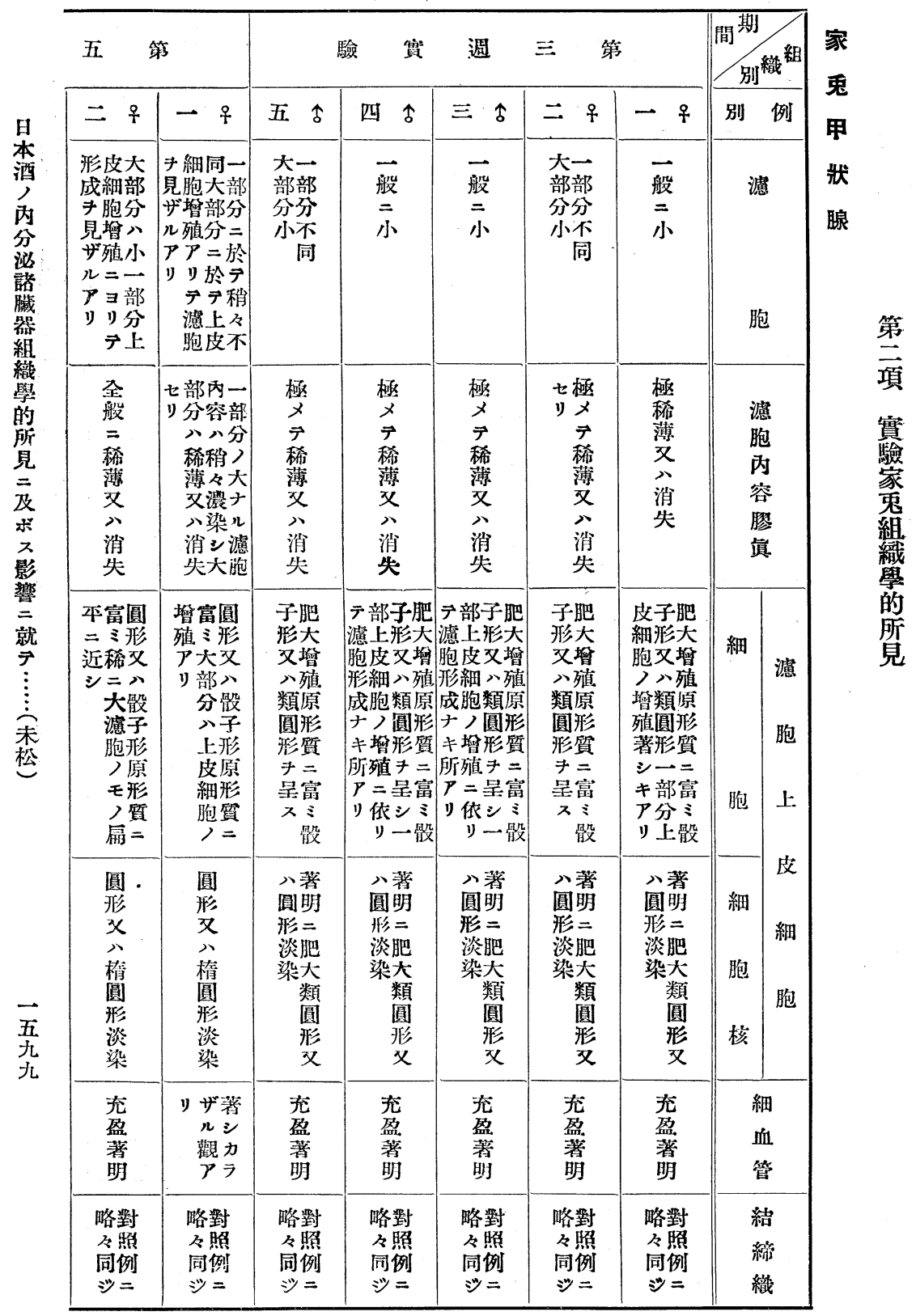




\begin{tabular}{|c|c|c|c|c|c|c|c|}
\hline \multicolumn{2}{|c|}{ 驗 } & 週 & \multicolumn{2}{|c|}{ 七 第 } & \multicolumn{3}{|c|}{ 驗實 } \\
\hline 五 令 & 四 5 & $\equiv \uparrow$ & $=$ 오 & $-q$ & 五 & 四 令。 & $\equiv \hat{\delta}$ \\
\hline $\begin{array}{l}\text { 八大 } \\
\text { 稍小 } \\
\text { 々稍 } \\
\text { 不々 } \\
\text { 正不 } \\
\text { 形同 } \\
\text { ナ形 } \\
\text { リ成 } \\
\text { 又 }\end{array}$ & $\begin{array}{c}\text { 成細一 } \\
\text { 少胞般 } \\
\text { シ增二 } \\
\text { 殖小 } \\
\text { シ } \\
\text { テシ } \\
\text { 濾 } \\
\text { 胞上. } \\
\text { 形皮 }\end{array}$ & $\begin{array}{l}\overrightarrow{f_{u}^{u}} \\
= \\
\text { 小 }\end{array}$ & $\begin{array}{l}\overrightarrow{\vec{n}} \\
\text { 般 } \\
= \\
\text { 小 }\end{array}$ & $\begin{array}{l}\overrightarrow{\text { 般 }} \\
= \\
\text { 小 }\end{array}$ & 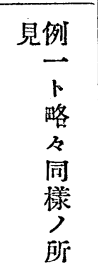 & 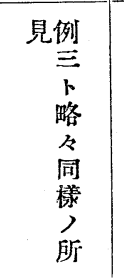 & 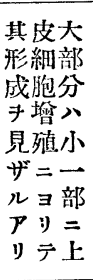 \\
\hline $\begin{array}{l}\text { 稀 } \\
\text { 薄 } \\
\text { 义 } \\
\text { 公 } \\
\text { 消 } \\
\text { 失 }\end{array}$ & $\begin{array}{l}\text { 稀 } \\
\text { 薄 } \\
\text { 入 } \\
\text { 八 } \\
\text { 消 } \\
\text { 失 } \\
\text { 七 } \\
\text { y }\end{array}$ & $\begin{array}{l}\text { セ稀 } \\
\text { 薄 } \\
\text { ナ } \\
\text { ル } \\
\text { カ } \\
\text { 又 } \\
\text { 爰 } \\
\text { 消 } \\
\text { 失 }\end{array}$ & $\begin{array}{l}\text { ド染多 } \\
\text { 消セク } \\
\text { 少ルハ } \\
\text { 七稀 } \\
\text { ル充溥 } \\
\text { ア霂 } \\
\text { リ稀等 } \\
= \\
= \\
\text { 殆淡 } \\
\end{array}$ & 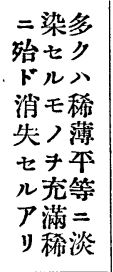 & \begin{tabular}{l} 
例 \\
\multirow{2}{*}{} \\
略 \\
各 \\
大 \\
同 \\
小 \\
異
\end{tabular} & 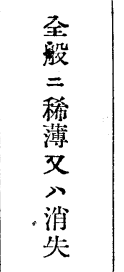 & $\begin{array}{l}\text { 全 } \\
\text { 般 } \\
= \\
\text { 稀 } \\
\text { 薄 } \\
\text { 足 } \\
\text { 公 } \\
\text { 消 } \\
\text { 失 }\end{array}$ \\
\hline 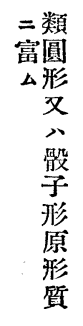 & $\begin{array}{c}\text { 二類 } \\
\text { 富圓 } \\
\text { 三形 } \\
\text { 增又 } \\
\text { 殖公 } \\
\text { 又骰 } \\
\text { 尒 } \\
\text { 形 } \\
\text { 原 } \\
\text { 形 } \\
\text { 筫 }\end{array}$ & $\begin{array}{l}=\text { 類 } \\
\text { 富圆 } \\
\text { 乏形 } \\
\text { 增又 } \\
\text { 殖公 } \\
\text { 又骰 } \\
\text { 子 } \\
\text { 形 } \\
\text { 原 } \\
\text { 形 } \\
\text { 質 }\end{array}$ & 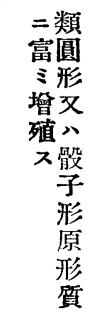 & 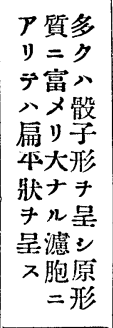 & 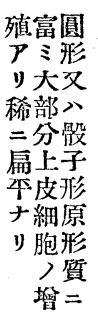 & 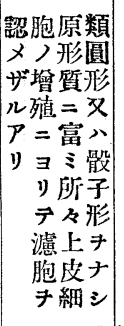 & $\begin{array}{c}\text { 形圆 } \\
\text { 質形 } \\
=\text { 又 } \\
\text { 富公 } \\
\text { A骰 } \\
\text { 子 } \\
\text { 形 } \\
= \\
\text { シ } \\
\text { テ } \\
\text { 原 }\end{array}$ \\
\hline $\begin{array}{l}\text { 又圓 } \\
\text { 形 } \\
\text { 父 } \\
\text { 㸆 } \\
\text { 圓 } \\
\text { 形 } \\
\text { 焱 } \\
\text { 染 }\end{array}$ & 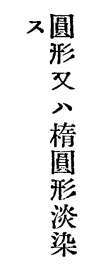 & $\begin{array}{l}\text { 又圓 } \\
\text { 形 } \\
\text { ·父 } \\
\text { 楕 } \\
\text { 圓 } \\
\text { 形 } \\
\text { 淡 } \\
\text { 染 }\end{array}$ & $\begin{array}{l}\text { 圓 } \\
\text { 形 } \\
\text { 及 } \\
\text { 公 } \\
\text { 棈 } \\
\text { 圓 } \\
\text { 形 } \\
\text { 淡 } \\
\text { 染 }\end{array}$ & 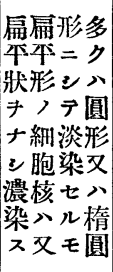 & $\begin{array}{l}\text { 圓 } \\
\text { 形 } \\
\text { 父 } \\
\text { 筩 } \\
\text { 圓 } \\
\text { 形 } \\
\text { 淡 } \\
\text { 染 }\end{array}$ & $\begin{array}{l}\text { 圓 } \\
\text { 形 } \\
\text { 父 } \\
\text { 公 } \\
\text { 楕 } \\
\text { 圆 } \\
\text { 形 } \\
\text { 淡 } \\
\text { 染 }\end{array}$ & $\begin{array}{l}\text { 圓 } \\
\text { 形 } \\
\text { 父 } \\
\text { 袏 } \\
\text { 圓 } \\
\text { 形 } \\
\text { 淡 } \\
\text { 染 }\end{array}$ \\
\hline $\begin{array}{l}\text { 變噛 } \\
\text { ナ照 } \\
\text { 战 } \\
\text { 著 }\end{array}$ & $\begin{array}{l}\text { 充 } \\
\text { 盈 } \\
\text { 著 } \\
\text { 明 }\end{array}$ & $\begin{array}{l}\text { 充 } \\
\text { 夃 } \\
\text { 著 } \\
\text { シ }\end{array}$ & $\begin{array}{l}\text { 充 } \\
\text { 盈 } \\
\text { 著 } \\
\text { シ }\end{array}$ & $\begin{array}{l}\text { 變噛 } \\
\text { 十照 } \\
\text { 贞 } \\
\text { 著 }\end{array}$ & $\begin{array}{l}\text { 充 } \\
\text { 盈 } \\
\text { 著 } \\
\text { 明 }\end{array}$ & $\begin{array}{l}\text { 充 } \\
\text { 盈 } \\
\text { 著 } \\
\text { 明 }\end{array}$ & $\begin{array}{l}\text { 充 } \\
\text { 盈 } \\
\text { 薏 } \\
\text { 跑 }\end{array}$ \\
\hline $\begin{array}{c}\text { 名對 } \\
\text { 同照 } \\
\text { 占 } \\
\text { 略 }\end{array}$ & $\begin{array}{l}\text { 略對 } \\
\text { 照 } \\
\text { 同例 } \\
\text { シ }\end{array}$ & 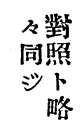 & $\begin{array}{l}\text { 略對 } \\
\text { 照 } \\
\text { 同例 } \\
\text { 沙 }=\end{array}$ & $\begin{array}{c}\text { 及對 } \\
\text { 同照 } \\
\text { 济 } \\
\text { 略 }\end{array}$ & $\begin{array}{l}\text { 略對 } \\
\text { 照 } \\
\text { 同例 } \\
シ ゙=\end{array}$ & $\begin{array}{l}\text { 略對 } \\
\text { 照 } \\
\text { 同例 } \\
\text { シ }\end{array}$ & $\begin{array}{l}\text { 略對 } \\
\text { 照 } \\
\text { 同例 } \\
\text { 湆= }\end{array}$ \\
\hline
\end{tabular}




\begin{tabular}{|c|c|c|c|c|c|c|c|c|}
\hline \multicolumn{2}{|c|}{ 第 } & \multicolumn{2}{|c|}{ 驗 } & 週 & \multicolumn{2}{|c|}{ 三 第 } & \multirow{2}{*}{ 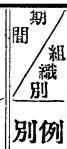 } & \multirow{2}{*}{$\begin{array}{l}\text { 各 } \\
\text { 葉 } \\
\text { 別 }\end{array}$} \\
\hline$=q$ & - +9 & 五 战 & 四 今 & 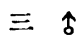 & $=q$ & - + & & \\
\hline $\begin{array}{l}\text { 1)肥 } \\
\text { 傾大 } \\
\text { 向增 } \\
\text { P殖 }\end{array}$ & $\begin{array}{l}\text { 變對 } \\
\text { ナ照 } \\
\text { シ } \\
\text { 著 }\end{array}$ & $\begin{array}{c}\text { ジ前 } \\
\text { 例 } \\
= \\
\text { 同 }\end{array}$ & $\begin{array}{c}\text { 浽前 } \\
\text { 例 } \\
= \\
\text { 同 }\end{array}$ & $\begin{array}{c}\text { シ前 } \\
\text { 例 } \\
= \\
\text { 同 }\end{array}$ & $\begin{array}{c}\text { シ前 } \\
\text { 例 } \\
= \\
\text { 同 }\end{array}$ & $\begin{array}{c}\text { リノ肥 } \\
\text { 傾大 } \\
\text { キ增 } \\
\text { P殖 }\end{array}$ & $\begin{array}{l}\text { 主 } \\
\text { 要 } \\
\text { 細 } \\
\text { 胞 }\end{array}$ & 前 \\
\hline $\begin{array}{l}\text { キ墄 } \\
\text { 觀少 } \\
\text { ア著 } \\
\text { リシ }\end{array}$ & $\begin{array}{l}\text { 觀稍 } \\
\text { P增 } \\
\text { リ殖 } \\
\text { J }\end{array}$ & $\begin{array}{c}\text { 湔 } \\
\text { 例 } \\
= \\
\text { 同 }\end{array}$ & $\begin{array}{c}\text { 洋前 } \\
\text { 例 } \\
= \\
\text { 同 }\end{array}$ & $\begin{array}{c}\text { 湔 } \\
\text { 例 } \\
= \\
\text { 同 }\end{array}$ & $\begin{array}{c}\text { 湔 } \\
\text { 例 } \\
= \\
\text { 同 }\end{array}$ & $\begin{array}{c}\text { 觀减 } \\
\text { 少 } \\
\text { リ七 } \\
\text { ル }\end{array}$ & $\begin{array}{l}\text { 嗜エ } \\
\text { 好オ } \\
\text { 細ジ } \\
\text { 胞ン }\end{array}$ & \\
\hline $\begin{array}{c}\text { 湔 } \\
\text { 例 } \\
= \\
\text { 同 }\end{array}$ & $\begin{array}{l}\text { 變對 } \\
\text { ナ照 } \\
\text { シ } \\
\text { 著 }\end{array}$ & $\begin{array}{c}\text { 浽前 } \\
\text { 例 } \\
= \\
\text { 同 }\end{array}$ & $\begin{array}{c}\text { 浽前 } \\
\text { 例 } \\
= \\
\text { 同 }\end{array}$ & $\begin{array}{c}\text { 差對 } \\
\text { ナ照 } \\
\text { シ } \\
\text { 大 }\end{array}$ & $\begin{array}{l}\text { キ减 } \\
\text { P少 } \\
\text { リ } \\
\text { 傾 }\end{array}$ & $\begin{array}{c}\text { 向减 } \\
\text { 少 } \\
\text { 傾 }\end{array}$ & $\begin{array}{l}\text { 毒 } \\
\text { 咾 } \\
\text { 好 } \\
\text { 細 } \\
\text { 胞 }\end{array}$ & \\
\hline $\begin{array}{c}\text { シ前 } \\
\text { 例 } \\
= \\
\text { 同 }\end{array}$ & $\begin{array}{l}\text { ス゚出 } \\
\text { 現 } \\
\Rightarrow \\
\text { 見 }\end{array}$ & $\begin{array}{c}\text { シ前 } \\
\text { 例 } \\
= \\
\text { 同 }\end{array}$ & $\begin{array}{c}\text { シ 前 } \\
\text { 例 } \\
= \\
\text { 同 }\end{array}$ & $\begin{array}{l}\text { 沙前 } \\
\text { 例 } \\
= \\
\text { 同 }\end{array}$ & $\begin{array}{c}\text { 見細三 } \\
\text { ル胞 } \\
\text { 間き } \\
=\text { 腺 }\end{array}$ & $ナ$ & $\begin{array}{l}\text { 膠 } \\
\text { 樣 } \\
\text { 小 } \\
\text { 球 }\end{array}$ & 葉 \\
\hline $\begin{array}{l}\text { 前 } \\
\text { 同 }\end{array}$ & $\begin{array}{l}\text { 著 } \\
\text { 變 } \\
\text { シ } \\
\text { シ }\end{array}$ & 同 & $\begin{array}{l}\text { 前 } \\
\text { 同 }\end{array}$ & $\begin{array}{l}\text { 前 } \\
\text { 同 }\end{array}$ & $\begin{array}{l}\text { 前 } \\
\text { 同 }\end{array}$ & $\begin{array}{l}\text { プ著 } \\
\text { 彎 } \\
\text { 年 } \\
\text { 見 }\end{array}$ & $\begin{array}{l}\text { 細 } \\
\text { 胞 } \\
\text { 位 } \\
\text { 核 }\end{array}$ & 中 \\
\hline $\begin{array}{l}\text { 前 } \\
\text { 列 } \\
= \\
\text { 同 } \\
\text { ジ }\end{array}$ & $\begin{array}{c}\text { トス膠 } \\
\text { 著ル樣 } \\
\text { 戀モ濾 } \\
\text { ナ對胞 } \\
\text { シ照存 }\end{array}$ & $\begin{array}{l}\text { 前 } \\
\text { 例 } \\
= \\
\text { 同 } \\
\text { 湆 }\end{array}$ & $\begin{array}{l}\text { 前 } \\
\text { 例 } \\
= \\
\text { 同 } \\
\text { 湆 }\end{array}$ & $\begin{array}{l}\text { 前 } \\
\text { 例 } \\
= \\
\text { 同 } \\
\text { 沙 }\end{array}$ & $\begin{array}{l}\text { 前 } \\
\text { 例 } \\
= \\
\text { 同 } \\
\text { シ }\end{array}$ & $\begin{array}{l}\text { ト洞ル膠 } \\
\text { 大ア濾質 } \\
\text { 差》胞き } \\
\text { ナ對樣充 } \\
\text { シ照空セ }\end{array}$ & $\begin{array}{l}\text { 膠 } \\
\text { 樣 } \\
\text { 濾 } \\
\text { 胞 }\end{array}$ & 葉 \\
\hline 同 & $\begin{array}{l}\text { 變 } \\
\text { 华 } \\
\text { ナ } \\
\text { シ }\end{array}$ & $\begin{array}{l}\text { 前 } \\
\text { 同 }\end{array}$ & $\begin{array}{l}\text { 前 } \\
\text { 同 }\end{array}$ & $\begin{array}{l}\text { 前 } \\
\text { 同 }\end{array}$ & $\begin{array}{l}\text { 前 } \\
\text { 同 }\end{array}$ & $\begin{array}{l}\text { 變 } \\
\text { 化 } \\
\text { ナ } \\
\text { シ }\end{array}$ & $\begin{array}{l}\text { 細 } \\
\text { 胞 }\end{array}$ & 後 \\
\hline $\begin{array}{l}\text { 前 } \\
\text { 例 } \\
= \\
\text { 同 } \\
\text { ジ }\end{array}$ & 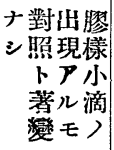 & $\begin{array}{l}\text { 前 } \\
\text { 例 } \\
= \\
\text { 同 } \\
\text { 湆 }\end{array}$ & $\begin{array}{l}\text { 前 } \\
\text { 例 } \\
= \\
\text { 同 } \\
\text { 湆 }\end{array}$ & $\begin{array}{l}\text { 前 } \\
\text { 例 } \\
= \\
\text { 同 } \\
\text { 湆 }\end{array}$ & $\begin{array}{l}\text { 前 } \\
\text { 例 } \\
= \\
\text { 同 } \\
\text { 沙 }\end{array}$ & $\begin{array}{l}\text { 照出膠 } \\
\text { ト現樣 } \\
\text { 差アア } \\
\text { ナリ滴 } \\
\text { シ對ノ }\end{array}$ & $\begin{array}{l}\text { 膠 } \\
\text { 樣 } \\
\text { 質 }\end{array}$ & 葉 \\
\hline 泛 & $\begin{array}{l}\text { 萌血 } \\
\text { 厚管 } \\
\text { 七稍 } \\
\text { リ }\end{array}$ & $\begin{array}{l}\text { 明充 } \\
\text { 盈 } \\
\text { 㮐 } \\
\text { 著 }\end{array}$ & 乏 & $\begin{array}{l}\text { 稍 } \\
\text { 乏 } \\
\text { シ }\end{array}$ & $\begin{array}{l}\text { 湔 } \\
\text { 例 } \\
= \\
\text { 同 }\end{array}$ & $\begin{array}{r}\text { 稍照充 } \\
\text { 著二盈 } \\
\text { シ比度 } \\
\text { シ對 }\end{array}$ & 管 & $\begin{array}{l}\text { 各 } \\
\text { 葉 }\end{array}$ \\
\hline $\begin{array}{l}\text { 前 } \\
\text { 同 }\end{array}$ & $\begin{array}{l}\text { 著 } \\
\text { 變 } \\
ナ \\
\text { シ }\end{array}$ & 前 & 前 & 前 & 前 & $\begin{array}{l}\text { 著 } \\
\text { 變 } \\
\text { オ } \\
\text { シ }\end{array}$ & $\begin{array}{l}\text { 結 } \\
\text { 締 } \\
\text { 織 }\end{array}$ & $\begin{array}{l}\text { 洪 } \\
\text { 通 }\end{array}$ \\
\hline
\end{tabular}




\begin{tabular}{|c|c|c|c|c|c|c|c|}
\hline \multicolumn{2}{|c|}{ 驗 } & 週 & \multicolumn{2}{|c|}{ 七 第 } & \multicolumn{3}{|c|}{ 驗 } \\
\hline 六 占 & 四 占 & $\equiv \hat{\delta}$ & $=9$ & $\rightarrow$ ㅇ & 五 占 & 四 & $\equiv \hat{\delta}$ \\
\hline $\begin{array}{l}\text { 著 } \\
\text { 變 } \\
\text { ナ } \\
\text { シ }\end{array}$ & $\begin{array}{c}\text { 湔 } \\
\text { 例 } \\
= \\
\text { 同 }\end{array}$ & $\begin{array}{c}\text { ジ前 } \\
\text { 例 } \\
= \\
\text { 同 }\end{array}$ & $\begin{array}{c}\text { 沙前 } \\
\text { 例 } \\
= \\
\text { 同 }\end{array}$ & $\begin{array}{l}\text { つ肥 } \\
\text { 觀大 } \\
\text { P算 } \\
\text { リ殖 }\end{array}$ & $\begin{array}{c}\text { シ前 } \\
\text { 例 } \\
= \\
\text { 同 }\end{array}$ & $\begin{array}{c}\text { 湔 } \\
\text { 例 } \\
= \\
\text { 同 }\end{array}$ & $\begin{array}{c}\text { 沙前 } \\
\text { 例 } \\
= \\
\text { 同 }\end{array}$ \\
\hline $\begin{array}{l}\text { 著 } \\
\text { 變 } \\
ナ \\
\text { シ } \\
\text { シ }\end{array}$ & $\begin{array}{c}\text { 湔 } \\
\text { 例 } \\
= \\
\text { 同 }\end{array}$ & $\begin{array}{c}\text { 沙前 } \\
\text { 例 } \\
= \\
\text { 同 }\end{array}$ & $\begin{array}{c}\text { 沙前 } \\
\text { 例 } \\
= \\
\text { 同 }\end{array}$ & $\begin{array}{c}\text { キ减 } \\
\text { 傾少 } \\
\text { 向著 } \\
ア ン\end{array}$ & $\begin{array}{c}\text { ジ前 } \\
\text { 例 } \\
= \\
\text { 同 }\end{array}$ & $\begin{array}{c}\text { 沙前 } \\
\text { 例 } \\
= \\
\text { 同 }\end{array}$ & $\begin{array}{c}\text { 湔 } \\
\text { 例 } \\
= \\
\text { 同 }\end{array}$ \\
\hline $\begin{array}{l}\text { 著 } \\
\text { 變 } \\
ナ \\
\text { シ } \\
\end{array}$ & $\begin{array}{l}\text { 向减 } \\
\text { 少 } \\
\text { 》傾 }\end{array}$ & $\begin{array}{c}\text { 浽前 } \\
\text { 例 } \\
= \\
\text { 同 }\end{array}$ & $\begin{array}{l}\text { 著 } \\
\text { 變 } \\
\text { ナ } \\
\text { シ }\end{array}$ & $\begin{array}{l}\text { 向减 } \\
\text { P少 } \\
\text { リ分 } \\
\text { 傾 }\end{array}$ & $\begin{array}{c}\text { 湔 } \\
\text { 例 } \\
= \\
\text { 同 }\end{array}$ & $\begin{array}{c}\text { 湔 } \\
\text { 例 } \\
= \\
\text { 同 }\end{array}$ & $\begin{array}{c}\text { シ前 } \\
\text { 列 } \\
= \\
\text { 同 }\end{array}$ \\
\hline $\begin{array}{l}\text { ル三腺 } \\
\text { 三細 } \\
\text { テ胞 } \\
\text { 見間 }\end{array}$ & $\begin{array}{l}\text { ズ出 } \\
\text { 現 } \\
\text { F } \\
\text { 見 }\end{array}$ & 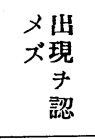 & $\begin{array}{c}\text { 湔 } \\
\text { 例 } \\
= \\
\text { 同 }\end{array}$ & $\begin{array}{l}\text { 出二腺 } \\
\text { 現三細 } \\
P \text { 第胞 } \\
\text { リノ間 }\end{array}$ & $\begin{array}{c}\text { 湔 } \\
\text { 例 } \\
= \\
\text { 同 }\end{array}$ & $\begin{array}{c}\text { 湔 } \\
\text { 茢 } \\
= \\
\text { 同 }\end{array}$ & $\begin{array}{c}\text { 沙前 } \\
\text { 例 } \\
= \\
\text { 同 }\end{array}$ \\
\hline $\begin{array}{l}\text { 著 } \\
\text { 變 } \\
\text { ナ } \\
\text { シ }\end{array}$ & $\begin{array}{l}\text { 變 } \\
\text { 华 } \\
ナ \\
\text { シ }\end{array}$ & 同 & 前 & $\begin{array}{c}\text { ズ變 } \\
\text { 华 } \\
\text { ₹ } \\
\text { 見 }\end{array}$ & 同 & 前 & 同 \\
\hline $\begin{array}{l}\text { 前 } \\
\text { 例 } \\
= \\
\text { 同 } \\
\text { 沙 }\end{array}$ & $\begin{array}{l}\text { 前 } \\
\text { 例 } \\
= \\
\text { 同 } \\
\text { 沙 }\end{array}$ & $\begin{array}{l}\text { 前 } \\
\text { 例 } \\
= \\
\text { 同 } \\
\text { 沙 }\end{array}$ & $\begin{array}{l}\text { 前 } \\
\text { 列 } \\
= \\
\text { 同 } \\
\text { ジ }\end{array}$ & 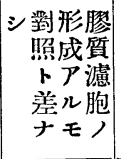 & $\begin{array}{l}\text { 前 } \\
\text { 列 } \\
= \\
\text { 同 } \\
\text { : }\end{array}$ & $\begin{array}{l}\text { 前 } \\
\text { 例 } \\
= \\
\text { 同 } \\
\text { 沙 }\end{array}$ & $\begin{array}{l}\text { 前 } \\
\text { 例 } \\
= \\
\text { 同 } \\
\text { 沙 }\end{array}$ \\
\hline 同 & $\begin{array}{l}\text { 前 } \\
\text { 同 }\end{array}$ & $\begin{array}{l}\text { 彎 } \\
\text { 华 } \\
ナ \\
\text { シ }\end{array}$ & $\begin{array}{c}\text { ブ變 } \\
\text { 化 } \\
\text { キ } \\
\text { 見 }\end{array}$ & $\begin{array}{l}\text { 縎 } \\
\text { 华 } \\
\text { ナ } \\
\text { シ }\end{array}$ & 同 & 前 & $\begin{array}{l}\text { 前 } \\
\text { 同 }\end{array}$ \\
\hline $\begin{array}{l}\text { 前 } \\
\text { 列 } \\
= \\
\text { 同 } \\
\text { 棌 }\end{array}$ & $\begin{array}{l}\text { 前 } \\
\text { 例 } \\
= \\
\text { 同 } \\
\text { 沙 }\end{array}$ & $\begin{array}{l}\text { 前 } \\
\text { 例 } \\
= \\
\text { 同 } \\
\text { 沙 }\end{array}$ & $\begin{array}{l}\text { 前 } \\
\text { 例 } \\
= \\
\text { 同 } \\
\text { : }\end{array}$ & $\begin{array}{l}\text { ト見小數 } \\
\text { 大ル滴滴 } \\
\text { 差壬出 } \\
\text { ナ對見膠 } \\
\text { シ照キ核 }\end{array}$ & $\begin{array}{l}\text { 前 } \\
\text { 列 } \\
= \\
\text { 同 } \\
\text { 沙 }\end{array}$ & $\begin{array}{l}\text { 前 } \\
\text { 例 } \\
= \\
\text { 同 } \\
\text { : }\end{array}$ & $\begin{array}{l}\text { 前 } \\
\text { 例 } \\
= \\
\text { 同 } \\
\text { ジ }\end{array}$ \\
\hline 前 & $\begin{array}{l}\text { 前 } \\
\text { 同 }\end{array}$ & $\begin{array}{l}\text { 天 } \\
\text { シ }\end{array}$ & 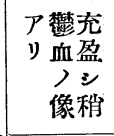 & 乏 & $\begin{array}{l}\sum \\
\Sigma\end{array}$ & 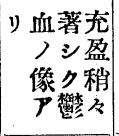 & $\begin{array}{l}\text { 前 } \\
\text { 闰 }\end{array}$ \\
\hline $\begin{array}{c}\text { 湔 } \\
\text { 例 } \\
= \\
\text { 同 }\end{array}$ & $\begin{array}{c}\text { 湔 } \\
\text { 例 } \\
= \\
\text { 同 }\end{array}$ & $\begin{array}{c}\text { ジ前 } \\
\text { 例 } \\
= \\
\text { 同 }\end{array}$ & $\begin{array}{c}\text { ジ前 } \\
\text { 列 } \\
= \\
\text { 同 }\end{array}$ & 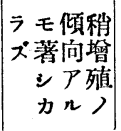 & 前 & 前 & 前 \\
\hline
\end{tabular}




\begin{tabular}{|c|c|c|c|c|c|c|c|c|}
\hline \multirow{4}{*}{ 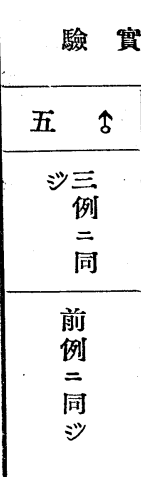 } & \multicolumn{2}{|c|}{ 遇 七 第 } & \multicolumn{2}{|c|}{ 驗實週五第 } & \multicolumn{3}{|c|}{ 驗 實 週三第 } & \multirow{2}{*}{ 别儌 } \\
\hline & 四 今 & $\equiv \hat{\delta}$ & 五 占 & 四 \{ & 五 今 & 四 占 & $\equiv \uparrow$ & \\
\hline & $\begin{array}{c}* \Xi \\
\text { 例 } \\
= \\
\text { 同 }\end{array}$ & $\begin{array}{l}\text { キ小- } \\
\text { ブナ般 } \\
\text { リル } \\
\text { 傾稍 }\end{array}$ & $\begin{array}{c}\text { 湔 } \\
\text { 例 } \\
= \\
\text { 同 }\end{array}$ & $\begin{array}{l}\text { 變對 } \\
\text { ナ照 } \\
\text { ン } \\
\text { 著 } \\
\end{array}$ & $\begin{array}{c}\text { 浽前 } \\
\text { 例 } \\
= \\
\text { 同 }\end{array}$ & $\begin{array}{c}\text { 浽前 } \\
\text { 例 } \\
= \\
\text { 同 }\end{array}$ & $\begin{array}{l}\text { 變對 } \\
\text { 十照 } \\
\text { シ } \\
\text { 著 } \\
\end{array}$ & $\begin{array}{l}\text { 細 } \\
\text { 精 } \\
\text { 管 }\end{array}$ \\
\hline & 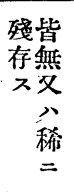 & 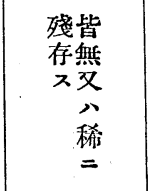 & $\begin{array}{l}\text { 前 } \\
\text { 例 } \\
= \\
\text { 同 } \\
\text { 浽 }\end{array}$ & $\begin{array}{l}\text { 存多减 } \\
\text { 在ク少 } \\
\text { 七稀七 } \\
n=n \\
\text { ア多モ } \\
\text { 》數ノ }\end{array}$ & $\begin{array}{l}\text { 殆 } \\
\text { F } \\
\text { 皆 } \\
\text { 無 }\end{array}$ & 同 & 無 & 精 \\
\hline 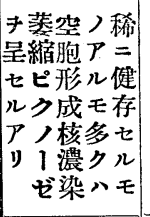 & $\begin{array}{l}\text { 㓴 } \\
\text { 同 } \\
\text { 沙 }\end{array}$ & 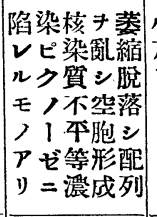 & 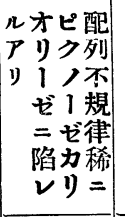 & 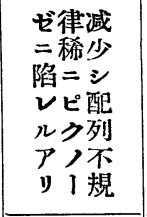 & $\begin{array}{l}\text { 薯 } \\
\text { 戀 } \\
\text { シ }\end{array}$ & $\begin{array}{l}\text { 前 } \\
\text { 例 } \\
= \\
\text { 同 } \\
\text { 严 }\end{array}$ & 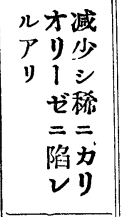 & $\begin{array}{l}\text { 精 } \\
\text { 子 } \\
\text { 細 } \\
\text { 胞 }\end{array}$ \\
\hline $\begin{array}{c}\text { 同知精 } \\
\text { クド子 } \\
\text { ス變細 } \\
\text { 化胞 } \\
\text { チト }\end{array}$ & $\begin{array}{l}\equiv \\
\text { 例 } \\
= \\
\text { 闹 } \\
\text { 沙 }\end{array}$ & 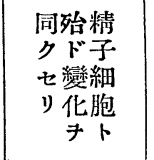 & 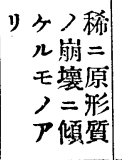 & 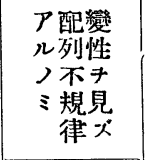 & 夙 & 前 & 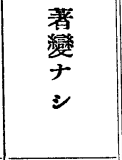 & $\begin{array}{l}\text { 精 } \\
\text { 囬 } \\
\text { 細 } \\
\text { 胞 }\end{array}$ \\
\hline 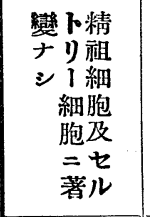 & 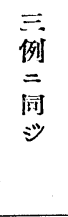 & 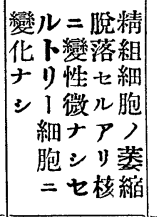 & 前 & $\begin{array}{l}\text { 著 } \\
\text { 變 } \\
\text { こ } \\
\text { ン }\end{array}$ & $\begin{array}{l}\text { 前 } \\
\text { 同 }\end{array}$ & $\begin{array}{l}\text { 前 } \\
\text { 同 }\end{array}$ & $\begin{array}{l}\text { 著 } \\
\text { 變 } \\
\text { シ } \\
\text { シ }\end{array}$ & $\mid$\begin{tabular}{|c} 
氏セ精 \\
細ルル組 \\
狍 $\mathbf{P}$ 細 \\
$\mathfrak{Y}$ 胞 \\
1 Z
\end{tabular} \\
\hline $\begin{array}{l}\text { 豆 } \\
\text { 例 } \\
\text { 同 } \\
\text { 湆 }\end{array}$ & $\begin{array}{l}\text { 茢 } \\
= \\
\text { 同 } \\
\text { 沙 }\end{array}$ & $\begin{array}{c}\text { チノ中一 } \\
\text { 見巨央部 } \\
\text { ル大細 } \\
\text { 細多精 } \\
\text { 胞核管 }\end{array}$ & $\begin{array}{l}\text { 認 } \\
x \\
\dot{z} \\
\stackrel{y}{*} \\
\ddot{*}\end{array}$ & 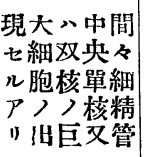 & 前 & $\begin{array}{l}\text { 認 } \\
\text { メ } \\
\text { ズ }\end{array}$ & 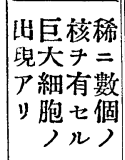 & \begin{tabular}{|l} 
兵 \\
細 \\
胞
\end{tabular} \\
\hline 萠 & 前 & $\begin{array}{l}\text { 䓔 } \\
\text { 變 } \\
\text { 今 } \\
\text { シ }\end{array}$ & 前 & 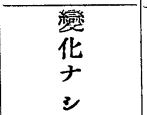 & 前 & 前 & $\begin{array}{l}\text { 變 } \\
\text { 华 } \\
\text { 丈 } \\
z\end{array}$ & $\begin{array}{l}\text { 間 } \\
\text { 細 } \\
\text { 胞 }\end{array}$ \\
\hline 秒 & $\begin{array}{l}\text { 稍 } \\
\text { 增 } \\
\text { 加 }\end{array}$ & 稍 & 前 & 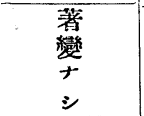 & 前 & 前 & 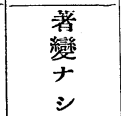 & $\begin{array}{l}\text { 締間 } \\
\text { 織漞 } \\
\text { 結 }\end{array}$ \\
\hline 前 & 前 & そ & 前 & 乏 & 前 & 前 & 稅 & 血 \\
\hline 同 & 同 & シ & 同 & シ & 同 & 同 & 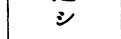 & 管 \\
\hline
\end{tabular}




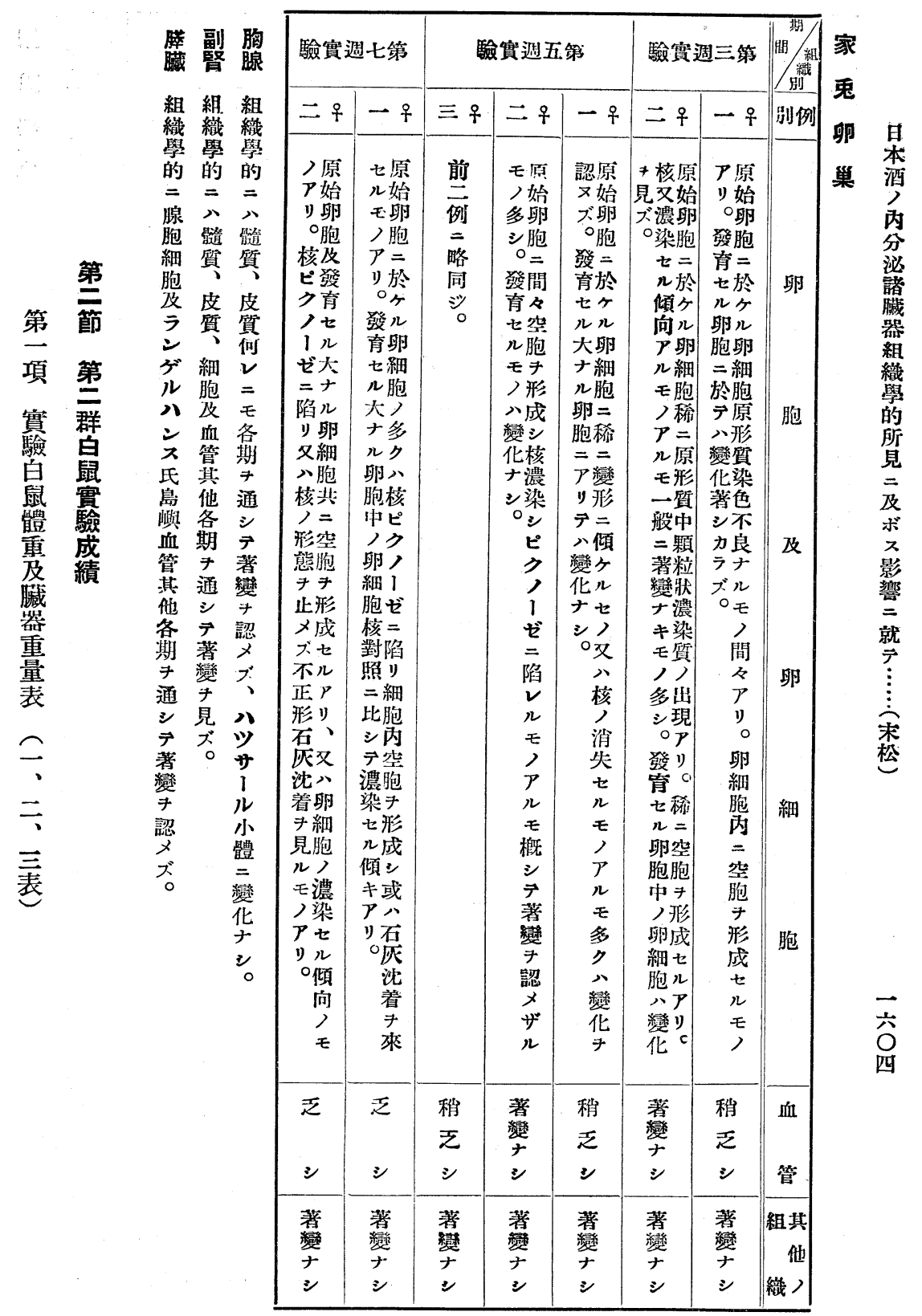


第一表 A 3 週 對照白鼠澧重表

\begin{tabular}{|c|c|c|c|c|c|c|c|}
\hline \multirow{2}{*}{ 日 } & \multicolumn{4}{|c|}{ 番 } & \multicolumn{2}{|c|}{ 號 } & \multirow[b]{2}{*}{ 本 均 } \\
\hline & $1 \uparrow$ & 25 & 3 ㅇ & 4 ㅇ & $5 \$$ & 6 ㅇ & \\
\hline 1 & 98 & 150 & 70 & 115 & 99 & 140 & 112 \\
\hline 3 & 105 & 145 & 73 & 115 & 105 & 145 & 114 \\
\hline 5 & 105 & 154 & 70 & 135 & 110 & 150 & 120 \\
\hline 7 & 123 & 142 & 96 & 145 & 112 & 156 & 127 \\
\hline 9 & 125 & 152 & 70 & 150 & 113 & 175 & 130 \\
\hline 11 & 130 & 152 & 74 & 155 & 115 & 187 & 138 \\
\hline 13 & 135 & 150 & 105 & 157 & 120 & 189 & 142 \\
\hline 15 & 140 & 159 & 105 & 160 & 125 & 185 & 146 \\
\hline 17 & 138 & 165 & 111 & 155 & 130 & 185 & 147 \\
\hline 19 & 130 & 175 & 113 & 160 & 125 & 190 & 150 \\
\hline 21 & 132 & 186 & 130 & 165 & 142 & 190 & 157 \\
\hline $\begin{array}{l}\text { 最始最終 } \\
\text { 蓸 重 美 }\end{array}$ & 34 & 36 & 60 & 50 & 43 & 50 & 44 \\
\hline
\end{tabular}

第一表 B 臟器 重 量 表

\begin{tabular}{|c|c|c|c|c|c|c|c|}
\hline \multirow{2}{*}{ 臟 器 名 } & \multicolumn{4}{|c|}{ 番 } & \multicolumn{2}{|c|}{ 號 } & \multirow[b]{2}{*}{ 平 均 } \\
\hline & $1 \hat{\delta}$ & $2 \hat{\jmath}$ & $3 q$ & 4 ㅇ & $5 \hat{8}$ & 6 ㅇ & \\
\hline 腦下垂體 & 0.005 & 0.007 & 0.005 & 0.006 & 0.006 & 0.007 & 0.006 \\
\hline$\%$ & 0.00878 & 0.00376 & 0.00384 & 0.00364 & 0.0042 & 0.00367 & 0.0382 \\
\hline 甲 狀 腺 & 0.018 & 0.023 & 0.016 & 0.027 & 0.018 & 0.030 & 0.022 \\
\hline$\%$ & 0.01363 & 0.01235 & 0.01281 & 0.01636 & 0.01267 & 0.01573 & 0.014 .01 \\
\hline 胸腺 & 0.280 & 0.1546 & 0.857 & 0.3401 & 0.1720 & 0.180 & 0.2481 \\
\hline$\%$ & 0.21212 & 0.08312 & 0.25154 & 0.20606 & 0.1211 & 0.0947 & 0.15802 \\
\hline 副 & 0.012 & 0.017 & 0.012 & 0.016 & 0.009 & 0.020 & 0.014 \\
\hline$\%$ & 0.00909 & 0.00849 & 0.010 & 0.00969 & 0.00638 & 0.010 .52 & 0.0089 \\
\hline 睪 如 & 0.792 & 0.954 & & & 0.879 & & 0.875 \\
\hline$\%$ & 0.59927 & 0.51296 & & & 0.6190 & & 0.5573 \\
\hline 卵监 & & & 0.012 & 0.037 & & 0.059 & 0.086 \\
\hline$\%$ & & & 0.00923 & 0.0226 & & 0.08105 & 0.02293 \\
\hline
\end{tabular}


第一表 G 3 週 實驗白鼠體重表

\begin{tabular}{|c|c|c|c|c|c|c|c|c|c|c|}
\hline \multirow{2}{*}{ 日 } & \multicolumn{10}{|c|}{ 號 } \\
\hline & $1+$ & 29 & 3 占 & $4 \hat{\delta}$ & 5 占 & 6 今 & 7 q & 8 웅 & 9 우 & 本 均 \\
\hline 1 & 102 & 107 & 67 & 87 & 75 & 150 & 100 & 127 & 65 & 97 \\
\hline 3 & 105 & 107 & 92 & 87 & 86 & 150 & 98 & 145 & 90 & 106 \\
\hline 5 & 107 & 112 & 87 & 83 & 82 & 156 & 100 & 150 & 90 & 107 \\
\hline 7 & 126 & 129 & 107 & 84 & 80 & 166 & 98 & 155 & 90 & 115 \\
\hline 9 & 130 & 132 & 115 & 83 & 82 & 152 & 102 & 155 & 85 & 115 \\
\hline 11 & 127 & 135 & 118 & 105 & 103 & 159 & 105 & 165 & 90 & 123 \\
\hline 13 & 142 & 142 & 127 & 110 & $110^{\circ}$ & 155 & 100 & 165 & 110 & 129 \\
\hline 15 & 140 & 145 & 125 & 110 & 108 & 165 & 112 & 170 & 95 & 130 \\
\hline 17 & 145 & 142 & 132 & 114 & 104 & 176 & 115 & 165 & 90 & 131 \\
\hline 19 & 147 & 145 & 133 & 120 & 108 & 180 & 120 & 175 & 95 & 126 \\
\hline 21 & 146 & 132 & 130 & 115 & 105 & 195 & 130 & 175 & 100 & 126 \\
\hline \begin{tabular}{|l|} 
最始最終 \\
體 重 盖
\end{tabular} & 44 & 25 & 63 & 28 & 30 & 45 & 30 & 48 & 35 & 39 \\
\hline
\end{tabular}

第一表 D 瀻 器 重 量 表

\begin{tabular}{|c|c|c|c|c|c|c|c|c|c|c|}
\hline \multirow{2}{*}{ 臟器名 } & \multicolumn{10}{|c|}{ 番 } \\
\hline & $1 q$ & 2 ㅇ & 3 古 & 4 占 & 5 占 & 6 今 & 7 우 & 8 웅 & 9 우 & 本 均 \\
\hline 下垂體 & 0.005 & 0.005 & 0.004 & 0.004 & 0.004 & 0.006 & 0.005 & 0.007 & 0.005 & 0.005 \\
\hline$\%$ & 0.0034 & 0.0038 & 0.0031 & 0.0084 & 0.0038 & 0.0031 & 0.0038 & 0.0040 & 0.005 & 0.0037 \\
\hline 甲 狀 腺 & 0.015 & 0.014 & 0.017 & 0.011 & 0.021 & 0.022 & 0.014 & 0.016 & 0.015 & 0.016 \\
\hline$\%$ & 0.0103 & 0.0106 & 0.0131 & 0.0096 & 0.020 & 0.0112 & 0.0108 & 0.0091 & 0.015 & 0.0118 \\
\hline & 0.2490 & 0.230 & 0.239 & 0.283 & 0.317 & 0.1495 & 0.1962 & 0.3623 & 0.1527 & 0.2420 \\
\hline$\%$ & 0.1705 & 0.1742 & 0.1838 & 0.2426 & 0.3069 & 0.0951 & 0.1509 & 0.2070 & 0.1527 & 0.1780 \\
\hline & 0.014 & 0.016 & 0.016 & 0.014 & 0.011 & 0.017 & 0.014 & 0.018 & 0.010 & 0.014 \\
\hline$\%$ & 0.0096 & 0.0121 & 0.0123 & 0.0122 & c.0105 & 0.0087 & 0.0108 & 0.0102 & 0.010 & 0.0108 \\
\hline 睪 丸 & & & 0.799 & 0.6918 & 0.8855 & 0.9476 & & & & 0.8185 \\
\hline$\%$ & & & 0.6146 & $0.601{ }^{\circ}$ & $0.79 \overline{7} 7$ & 0.4399 & & & & 0.6018 \\
\hline & 0.014 & 0.022 & & & & & 0.059 & 0.044 & 0.024 & 0.031 \\
\hline$\%$ & $D_{0}$ & 0.01 & & & & & 0.0454 & 0.0251 & 0.024 & 0.0228 \\
\hline
\end{tabular}


第二表 A 5 週 對照白鼠體重表

\begin{tabular}{|c|c|c|c|c|c|c|c|}
\hline \multirow{2}{*}{ 數 } & \multicolumn{3}{|c|}{ 番 } & \multicolumn{4}{|c|}{ 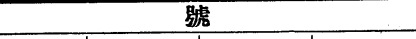 } \\
\hline & $1, \hat{\delta}$ & 2 古 & 3 운 & 4 우 & 5 우 & 6 เ & 本均 \\
\hline 1 & 101 & 105 & 90 & 140 & 115 & 75 & 104 \\
\hline 3 & 105 & 100 & 90 & 140 & 120 & 73 & 104 \\
\hline 5 & 112 & 107 & 98 & 145 & 129 & 76 & 111 \\
\hline 7 & 123 & 95 & 127 & 146 & 133 & 77 & 116 \\
\hline 9 & 127 & 109 & 128 & 144 & 136 & 85 & 121 \\
\hline 11 & 130 & 109 & 128 & 150 & 142 & 90 & 125 \\
\hline 13 & 140 & $1(9$ & 120 & 150 & 147 & 98 & 127 \\
\hline 15 & 145 & 115 & 123 & 154 & 150 & 102 & 131 \\
\hline 17 & 138 & 125 & 142 & 155 & 145 & 105 & 135 \\
\hline 19 & 137 & 133 & 149 & 158 & 148 & 110 & 189 \\
\hline 21 & 138 & 141 & 141 & 158 & 150 & 115 & 140 \\
\hline 23 & 140 & 148 & 152 & 161 & 147 & 127 & 145 \\
\hline 25 & 148 & 158 & 155 & 161 & 152 & 129 & 150 \\
\hline 27 & 145 & 160 & 158 & 164 & 165 & 130 & 153 \\
\hline 29 & 151 & 154 & 155 & 165 & 165 & 134 & 155 \\
\hline 31 & 145 & 161 & 158 & 158 & 166 & 138 & 154 \\
\hline 33 & 143 & 160 & 155 & 160 & 168 & 142 & 154 \\
\hline 35 & 140 & 145 & 164 & 170 & 170 & 140 & 152 \\
\hline $\begin{array}{l}\text { 始最終 } \\
\text { 重差 }\end{array}$ & 39 & 51 & 55 & 24 & 55 & 65 & 49 \\
\hline
\end{tabular}

第二表 B 臟 器 重 量 表

\begin{tabular}{|c|c|c|c|c|c|c|c|}
\hline \multirow{2}{*}{ 価器 名 } & \multicolumn{4}{|c|}{ 番 } & \multicolumn{2}{|c|}{ 號 } & \multirow[b]{2}{*}{ 平 均 } \\
\hline & 1 f & 2 战 & 3 q & 4 ㅇ & $5 q$ & 6 今 & \\
\hline 腦下垂體 & 0.005 & 0.007 & 0.005 & 0.007 & 0.005 & 0.009 & 0.006 \\
\hline$\%$ & 0.00357 & 0.00448 & 0.00344 & 0.0043 & 0.00294 & 0.00542 & 0.00894 \\
\hline 甲 爿 㟫 & 0.019 & 0.029 & 0.014 & 0.024 & 0.018 & 0.014 & 0.019 \\
\hline$\%$ & 0.01357 & 0.0186 & 0.0097 & 0.0146 & 0.01058 & 0.0100 & 0.0125 \\
\hline 胸腺 & 0.1719 & 0.2040 & 0.2593 & 0.1560 & 0.2250 & 0.1880 & 0.2015 \\
\hline$\%$ & 0.12279 & 0.1308 & 0.1788 & 0.0951 & 0.13285 & 0.1342 & 0.1325 \\
\hline & 0.016 & 0.010 & 0.017 & 0.024 & 0.016 & 0.015 & 0.016 \\
\hline$\%$ & 0.01142 & 0.0067 & 0.014 & 0.0142 & 0.00941 & 0.01071 & 0.01052 \\
\hline 睪 丸 & 0.7174 & 0.8425 & & & & 0.8327 & 0.7975 \\
\hline$\%$ & 0.51246 & 0.5689 & & & & 0.59407 & 0.5246 \\
\hline 卵巢 & & & 0.019 & 0.057 & 0.042 & & 0.039 \\
\hline$\%$ & & & 0.0131 & 0.085 & 0.0247 & & 0.0256 \\
\hline
\end{tabular}




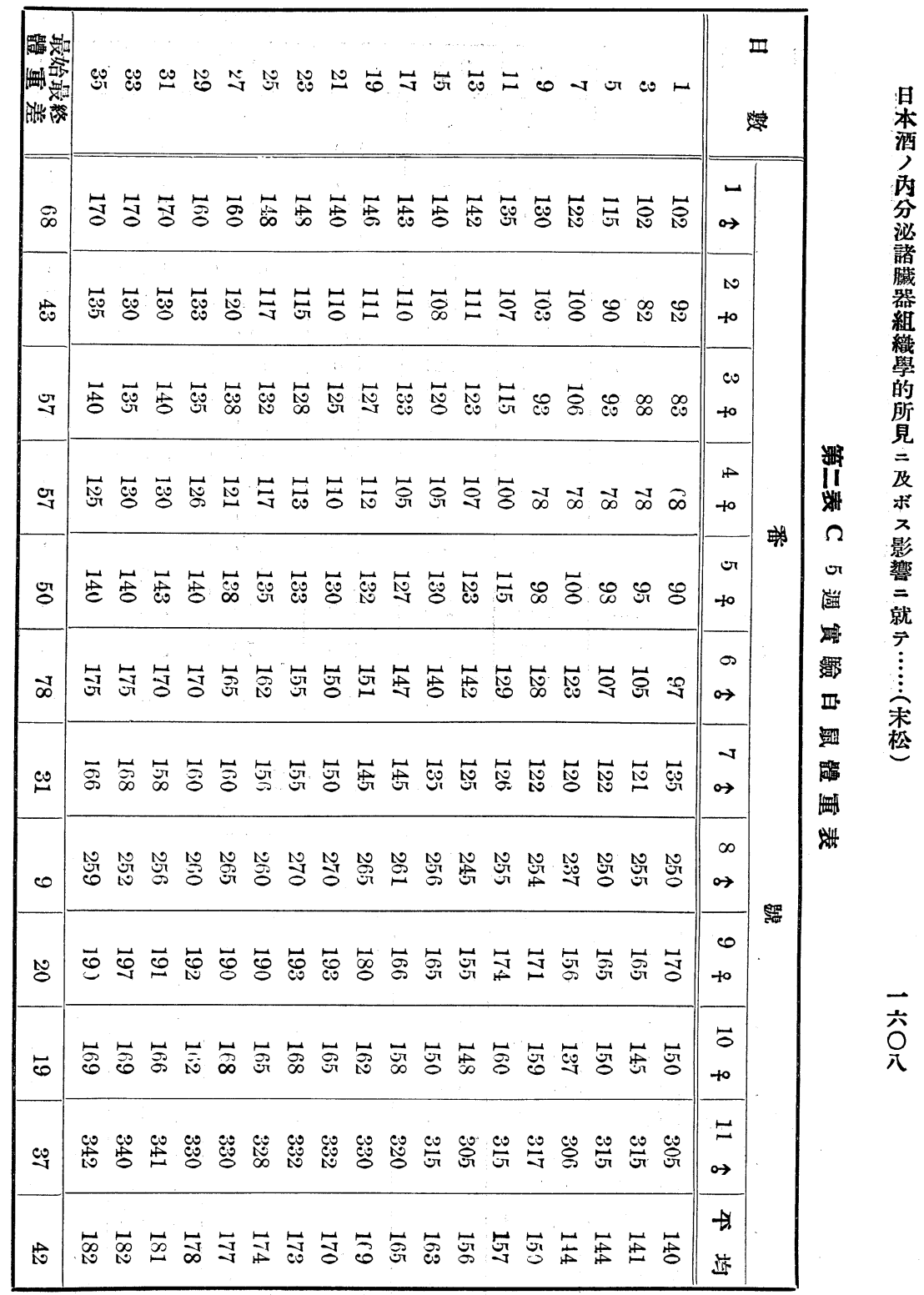




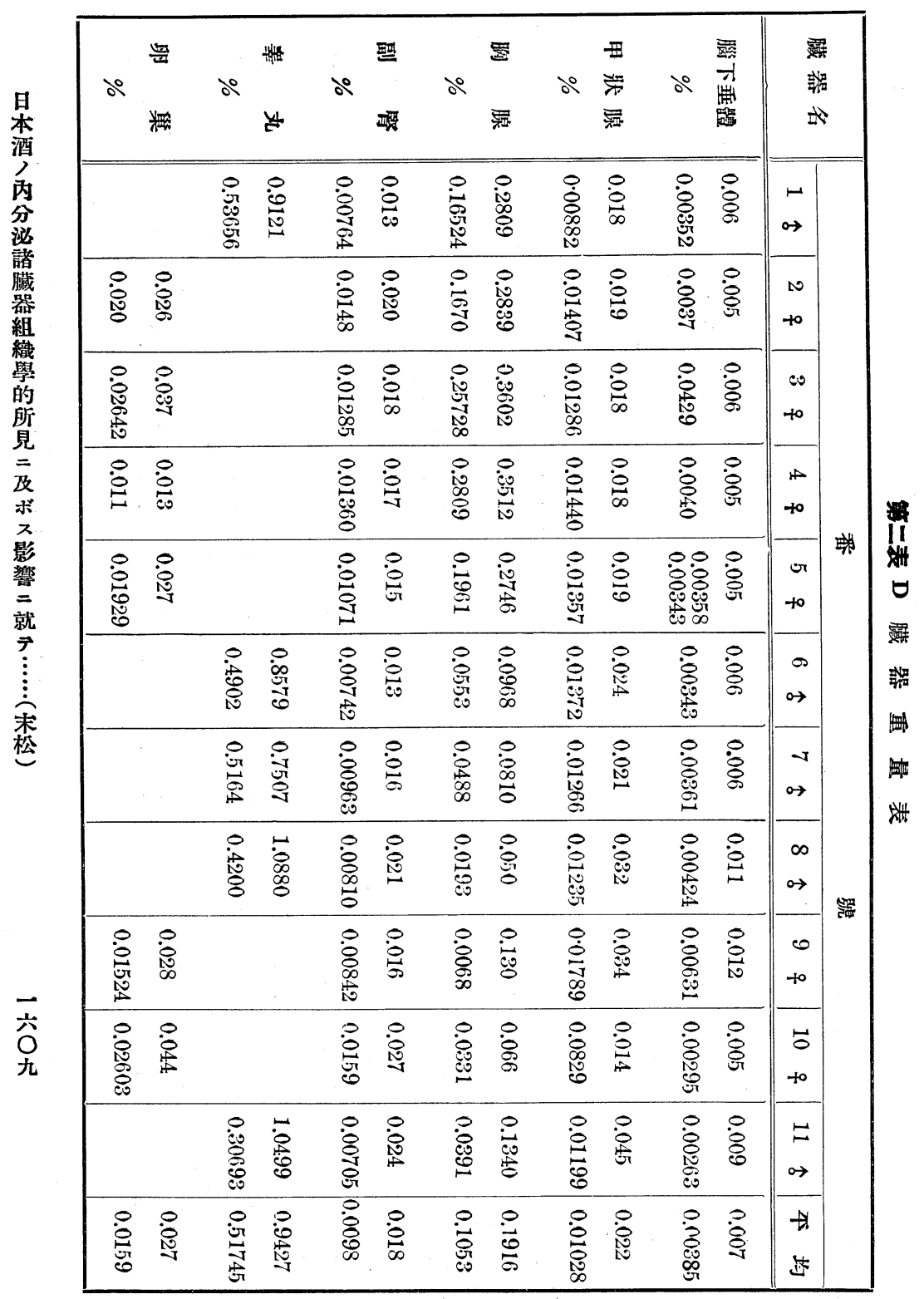


第三表 A 7 週 對照白鼠體重表

\begin{tabular}{|c|c|c|c|c|c|c|c|}
\hline \multirow{2}{*}{ 日 } & \multicolumn{7}{|c|}{ 號 } \\
\hline & $1 \hat{s}$ & $2 \hat{\jmath}$ & 3 우 & 4 우 & 5 우 & 6 占 & 本 均 \\
\hline 1 & 85 & 98 & 105 & 160 & 120 & 127 & 117 \\
\hline 3 & 90 & 100 & 108 & 163 & 125 & 130 & 117 \\
\hline 5 & 92 & 102 & 110 & 153 & 130 & 135 & 1.22 \\
\hline 7 & 108 & 102 & 123 & 156 & 138 & 139 & 127 \\
\hline 9 & 127 & 112 & 120 & 165 & 140 & 145 & 136 \\
\hline 11 & 113 & 115 & 125 & 166 & 142 & 155 & 186 \\
\hline 13 & 125 & 125 & 143 & 150 & 150 & 168 & 143 \\
\hline 15 & 125 & 125 & 142 & 150 & 155 & 165 & 143 \\
\hline 17 & 149 & 133 & 153 & 150 & 162 & 170 & 152 \\
\hline 19 & 130 & 135 & 157 & 156 & 166 & 175 & 153 \\
\hline 21 & 142 & 138 & 150 & 158 & 172 & 182 & 157 \\
\hline 23 & 140 & 139 & 160 & 159 & 170 & 180 & 160 \\
\hline 25 & 140 & 135 & 163 & 163 & 175 & 187 & 163 \\
\hline 27 & 143 & 144 & 165 & 166 & 182 & 195 & 165 \\
\hline 29 & 145 & 147 & 170 & 170 & 188 & 200 & 170 \\
\hline 31 & 145 & 148 & 175 & 160 & 192 & 205 & 170 \\
\hline 33 & 143 & 142 & 175 & 167 & 200 & 212 & 178 \\
\hline 35 & 150 & 147 & 175 & 163 & 198 & 212 & 173 \\
\hline 37 & 155 & 145 & 175 & 160 & 190 & 210 & 173 \\
\hline 39 & 155 & 143 & 180 & 158 & 190 & 208 & 172 \\
\hline 41 & 165 & 145 & 185 & 160 & 190 & 210 & 173 \\
\hline 43 & 163 & 145 & 190 & 170 & 200 & 213 & 180 \\
\hline 45 & 165 & 145 & 183 & 170 & 200 & 205 & 178 \\
\hline 47 & 170 & 143 & 193 & 175 & 198 & 210 & 181 \\
\hline 49 & 179 & 150 & 200 & 178 & 206 & 205 & 185 \\
\hline $\begin{array}{l}\text { 最始最終 } \\
\text { 體 重 美 }\end{array}$ & 88 & 52 & $9 . \bar{j}$ & 18 & 86 & 78 & 68 \\
\hline \multicolumn{8}{|c|}{ 第三表 $\mathbf{B}$} \\
\hline \multirow{2}{*}{ 臟 器名 } & \multicolumn{4}{|c|}{ 番 } & \multirow{2}{*}{ 號 } & & \\
\hline & 1 占 & $2 \hat{s}$ & $3+$ & 4 웅 & & 6 古 & 平均 \\
\hline \multirow{4}{*}{$\begin{array}{c}\text { 腦下垂體 } \\
\% \\
\text { 甲 狀 腺 } \\
\%\end{array}$} & 0.005 & 0.005 & 0.007 & 0.008 & 0.010 & 0.010 & 0.007 \\
\hline & 0.0029 & 0.0033 & 0.0035 & 0.0045 & 0.0048 & 0.0049 & 0.0038 \\
\hline & 0.017 & 0.018 & 0.018 & 0.024 & 0.021 & 0.021 & 0.019 \\
\hline & 0.0093 & 0.012 & 0.009 & 0.0135 & 0.0102 & 0.0103 & 0.0103 \\
\hline 胸 & 0.120 & 0.108 & 0.2605 & 0.114 & 0.144 & 0.222 & 0.1614 \\
\hline$\%$ & 0.0694 & 0.072 & 0.1303 & 0.0641 & 0.0699 & 0.1083 & 0.0873 \\
\hline \multirow[b]{2}{*}{$\%$} & 0.014 & 0.015 & 0.020 & 0.020 & 0.018 & 0.015 & 0.017 \\
\hline & 0.0081 & 0.010 & 0.010 & 0.0112 & 0.0088 & 0.0073 & 0.0092 \\
\hline \multirow{2}{*}{ 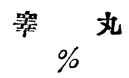 } & 0.9146 & 0.7808 & & & & 1.2306 & 0.9753 \\
\hline & 0.5287 & 0.5205 & & & & 0.6029 & 0.5272 \\
\hline 卵 巢 & & & 0.053 & 0.022 & 0.039 & & 0.038 \\
\hline$\%$ & & & 0.0265 & 0.0124 & 0.0189 & & 0.0206 \\
\hline
\end{tabular}


第三表 $\mathbf{C} 7$ 週 窅驗白鼠體重表

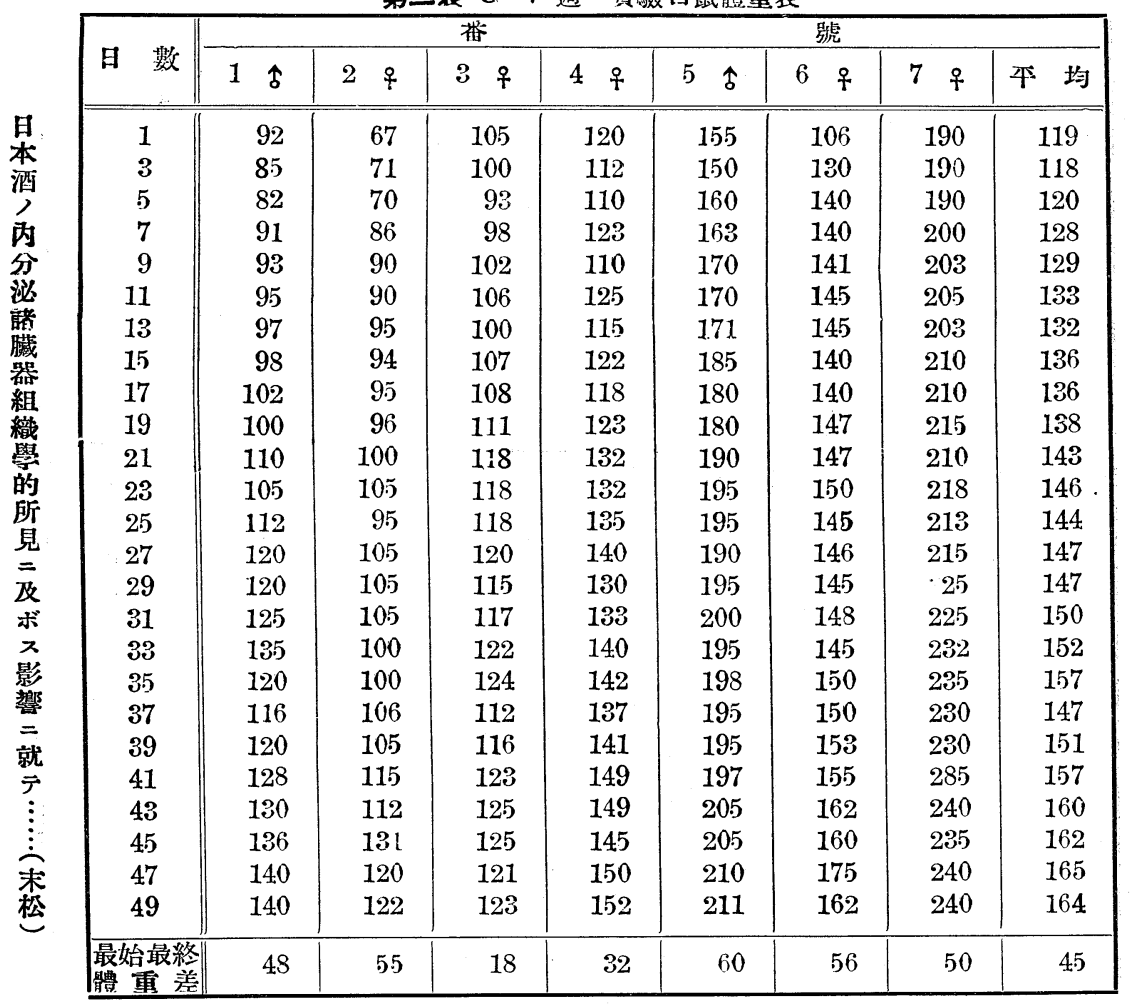

第三表 D 臟 器 重 量 表

\begin{tabular}{|c|c|c|c|c|c|c|c|c|}
\hline \multirow{2}{*}{ 臟器名 } & \multicolumn{5}{|c|}{ 番 } & \multicolumn{2}{|l|}{ 易 } & \multirow[b]{2}{*}{ 本 均 } \\
\hline & $1 \hat{\jmath}$ & 2 ㅇ & 3 우 & 4 우 & 5 占 & 6 ㅇ & 7 占 & \\
\hline 腦下垂體 & 0.007 & 0.005 & 0.005 & 0.006 & 0.006 & 0.006 & 0.009 & 0.006 \\
\hline$\%$ & 0.005 & 0.0041 & 0.0041 & 0.0039 & 0.0028 & 0.0037 & 0.0038 & 0.0037 \\
\hline 甲 爿 腺 & 0.017 & 0.016 & 0.016 & 0.024 & 0.023 & 0.018 & 0.027 & 0.020 \\
\hline$\%$ & 0.0121 & 0.0120 & 0.0120 & 0.0157 & 0.0109 & 0.0111 & 0.0113 & 0.01219 \\
\hline 胸腺 & 0.230 & 0.194 & 0.093 & 0.188 & 0.2414 & 0.2189 & 0.3031 & 0.2097 \\
\hline$\%$ & 0.1643 & 0.1590 & 0.0756 & 0.1237 & 0.1149 & 0.1351 & 0.1263 & 0.1275 \\
\hline 副 筒 & 0.012 & 0.013 & 0.022 & 0.023 & 0.019 & 0.026 & 0.018 & 0.0197 \\
\hline$\%$ & 0.0085 & 0.0107 & 0.0179 & 0.0131 & 0.009 & 0.016 & 0.0075 & 0.0116 \\
\hline 犰 & 0.9124 & & & & 0.8949 & & 0.9453 & 0.9178 \\
\hline$\%$ & 0.6517 & & & & 0.4241 & & 0.3939 & 0.5596 \\
\hline |卵毣 & & 0.019 & 0.046 & 0.047 & & 0.046 & & 0.038 \\
\hline$\%$ & & 0.0156 & 0.0374 & 0.0309 & & 0.0284 & & 0.0232 \\
\hline
\end{tabular}




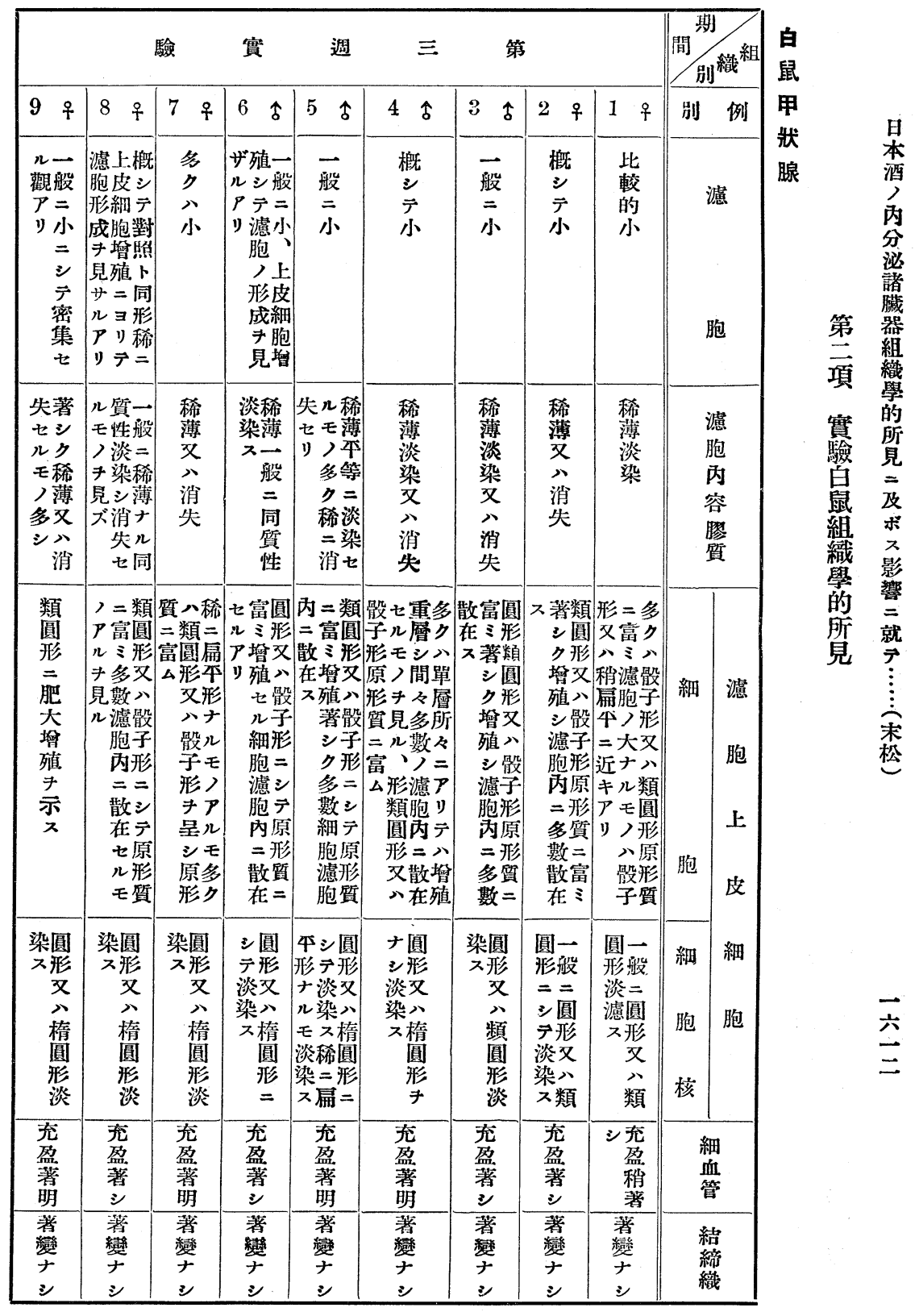




\begin{tabular}{|c|c|c|c|c|c|c|c|c|c|c|}
\hline 驗 & 實 & \multicolumn{2}{|l|}{ 週 } & 五 & \multicolumn{4}{|l|}{ 第 } & \multicolumn{2}{|c|}{ 别/間繶 } \\
\hline 9 우 & 8 今 & 7 今 & 6 今 & 5 우 & 4 오 & 3 우 & 2 우 & $1 \$$ & 別 & 例 \\
\hline $\begin{array}{l}\text { ナ感 } \\
\text { ル般 } \\
\text { 觀二 } \\
\text { ア稍 } \\
\text { リ小 }\end{array}$ & $\begin{array}{c}\text { 大モ稀 } \\
\text { 羕ノア } \\
\text { ナア } \\
\text { シルナ } \\
\text { モル }\end{array}$ & $\begin{array}{c}\text { 觀稍 } \\
\text { P縮 } \\
\text { 小 } \\
\text { セ } \\
\text { ル }\end{array}$ & $\begin{array}{c}\text { 著大 } \\
\text { 變サ } \\
\text { ナ對 } \\
\text { シ照 } \\
\text { ト }\end{array}$ & $\begin{array}{c}\text { 大大 } \\
\text { 差サ } \\
\text { ナ對 } \\
\text { シ照 } \\
\text { ト }\end{array}$ & $\begin{array}{c}\text { ナ對 } \\
\text { シ照 } \\
⺊ \\
\text { 太 } \\
\text { 差 }\end{array}$ & 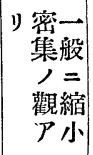 & $\begin{array}{l}\text { ナ對 } \\
\text { シ照 } \\
\stackrel{1}{ト} \\
\text { 著 } \\
\text { 變 }\end{array}$ & $\begin{array}{l}\overrightarrow{i_{u}} \\
= \\
\text { 小 }\end{array}$ & 胅 & 抱 \\
\hline 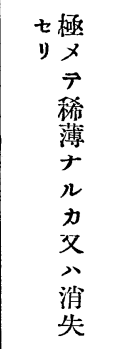 & 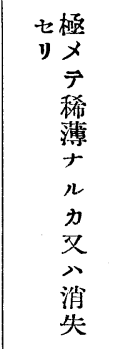 & 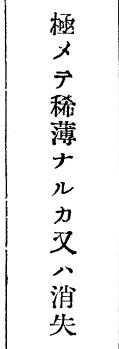 & $\begin{array}{c}\text { 色一 } \\
\text { 多般 } \\
\text { 少二 } \\
\text { J充 } \\
\text { 濃霂 } \\
\text { 淡セ } \\
P ル \\
\text { リ } \\
\text { 多 } \\
\text { 多 } \\
\text { 染 }\end{array}$ & 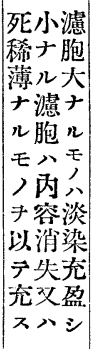 & 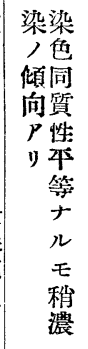 & 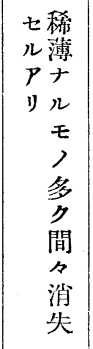 & 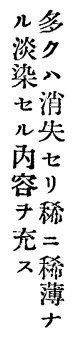 & $\begin{array}{l}\text { 穕 } \\
\text { 薄 } \\
\text { 公 } \\
\text { 消 } \\
\text { 失 }\end{array}$ & & 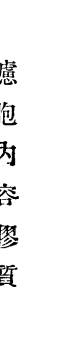 \\
\hline 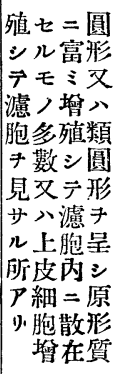 & 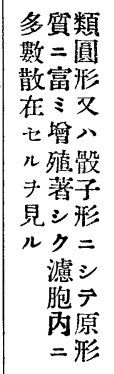 & 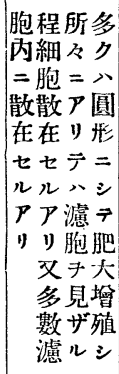 & 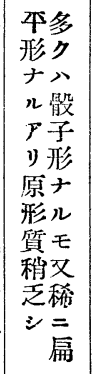 & \begin{tabular}{|c|} 
リ質類 \\
國 \\
富形 \\
乏又 \\
濾 \\
胞骰 \\
内子 \\
$=$ 形 \\
多二 \\
數 \\
散 \\
在原 \\
七形
\end{tabular} & 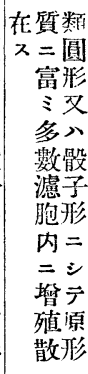 & 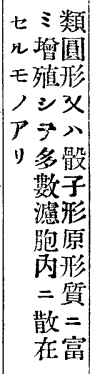 & $\begin{array}{l}\text { 多 } \\
\text { ク } \\
\text { 八 } \\
\text { 䯎 } \\
\text { 子 } \\
\text { 形 } \\
7 \\
\text { 是 } \\
\text { x }\end{array}$ & 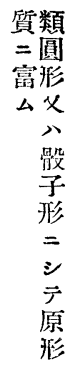 & 胞 & $\begin{array}{l}\text { 濾 } \\
\text { 胞 } \\
\text { 上 }\end{array}$ \\
\hline 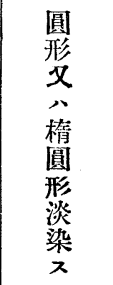 & 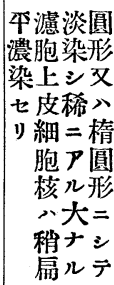 & $\begin{array}{c}\text { 淡圓 } \\
\text { 染形 } \\
\text { ス文 } \\
\text { 類 } \\
\text { 圓 } \\
\text { 形 } \\
= \\
\text { シ } \\
\text { テ }\end{array}$ & 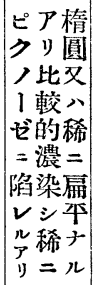 & 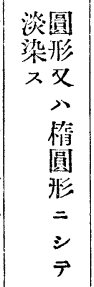 & 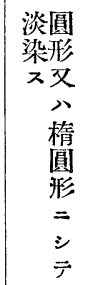 & $\begin{array}{l}\text { 圓 } \\
\text { 形 } \\
\text { 刃 } \\
\text { 楕 } \\
\text { 㘣 } \\
\text { 形 } \\
\text { 淡 } \\
\text { 染 } \\
\text { 又 }\end{array}$ & 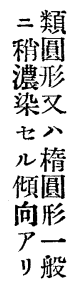 & 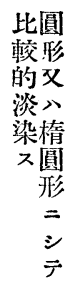 & 榜 & 胞 \\
\hline $\begin{array}{l}\text { 充 } \\
\text { 盈 } \\
\text { 著 } \\
\text { 明 }\end{array}$ & $\begin{array}{l}\text { 充 } \\
\text { 夃 } \\
\text { 著 } \\
\text { 明 }\end{array}$ & $\begin{array}{l}\text { 充 } \\
\text { 盈 } \\
\text { 著 } \\
\text { 明 }\end{array}$ & $\begin{array}{c}\text { 力充 } \\
\text { ラ盈 } \\
\text { ズ著 } \\
\text { シ }\end{array}$ & $\begin{array}{l}\text { 充 } \\
\text { 夃 } \\
\text { 著 } \\
\text { 晋 }\end{array}$ & $\begin{array}{l}\text { 充 } \\
\text { 盈 } \\
\text { 著 } \\
\text { 明 }\end{array}$ & 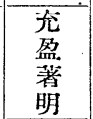 & $\begin{array}{l}\text { 稍 } \\
\text { 著 } \\
\text { シ }\end{array}$ & $\begin{array}{l}\text { 秒 } \\
\text { 著 } \\
\text { シ }\end{array}$ & & \\
\hline $\begin{array}{l}\text { 變 } \\
\text { 华 } \\
\text { ナ } \\
\text { シ }\end{array}$ & $\begin{array}{l}\text { 變 } \\
\text { 华 } \\
\text { ナ } \\
\text { シ }\end{array}$ & $\begin{array}{l}\text { 變 } \\
\text { 华 } \\
\text { ナ } \\
\text { シ }\end{array}$ & $\begin{array}{l}\text { 變 } \\
\text { 化 } \\
\text { ナ } \\
\text { シ }\end{array}$ & $\begin{array}{l}\text { 化 } \\
\text { 變 } \\
+ \\
シ\end{array}$ & $\begin{array}{l}\text { 變 } \\
\text { 化 } \\
\text { ナ } \\
\text { シ }\end{array}$ & $\begin{array}{l}\text { 變 } \\
\text { 化 } \\
+ \\
\text { シ }\end{array}$ & $\begin{array}{l}\text { 綧 } \\
\text { 化 } \\
+ \\
シ\end{array}$ & $\begin{array}{l}\text { 變 } \\
\text { 华 } \\
\text { ナ } \\
\text { ע }\end{array}$ & & 綕 \\
\hline
\end{tabular}




\begin{tabular}{|c|c|c|c|c|c|c|c|c|}
\hline \multirow[b]{2}{*}{7 우 } & 唡 & 實 & 週 & 七 & \multicolumn{2}{|l|}{ 第 } & \multicolumn{2}{|c|}{ 間/期/縚組 } \\
\hline & 6 9 & 5 令 & 4 우 & 3 占 & 2 우 & $1 \uparrow$ & 别 & 例 \\
\hline $\begin{array}{l}\text { ナー } \\
\text { ル般 } \\
\text { ガ二 } \\
\text { 如稍 } \\
\text { シ小 }\end{array}$ & 稍 & $\begin{array}{c}\text { ノ稍 } \\
\text { 多大 } \\
\text { シナ } \\
ル \\
モ\end{array}$ & $\begin{array}{c}\text { 觀稍 } \\
\text { ア大 } \\
\text { リナ } \\
\text { ル } \\
\text { ノ }\end{array}$ & 小 & $\begin{array}{c}\text { 同稍 } \\
P \text { 大 } \\
\text { リサ } \\
= \\
\text { 不 }\end{array}$ & $\begin{array}{c}\text { 美治 } \\
\text { ナド } \\
\text { シ對 } \\
\text { 照 } \\
\text { ト }\end{array}$ & & 胞 \\
\hline $\begin{array}{l}\text { 稀 } \\
\text { 薄 } \\
\text { 又 } \\
\text { 公 } \\
\text { 消 } \\
\text { 失 }\end{array}$ & $\begin{array}{l}\text { モ稀 } \\
\text { 溥 } \\
\text { P淡 } \\
\text { リ染 } \\
\text { 染 } \\
\text { 消 } \\
\text { 失 } \\
\text { 七 } \\
\text { ル }\end{array}$ & 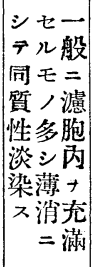 & 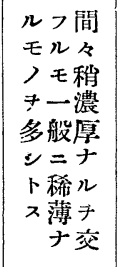 & $\begin{array}{c}\text { 淡稀 } \\
\text { 染薄 } \\
\text { ス消 } \\
\text { 又 } \\
\text { 父 } \\
\text { 火 } \\
\text { 七 } \\
\text { y } \\
\text { v }\end{array}$ & 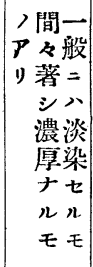 & 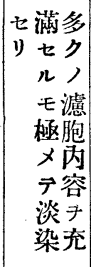 & & $\begin{array}{l}\text { 濾 } \\
\text { 胞 } \\
\text { 內 } \\
\text { 蓉 } \\
\text { 翏 } \\
\text { 質 }\end{array}$ \\
\hline 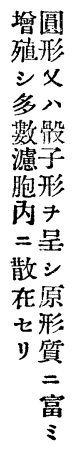 & 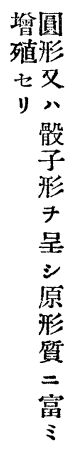 & 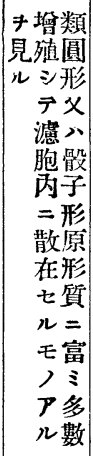 & 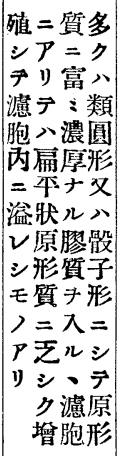 & 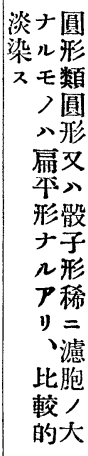 & 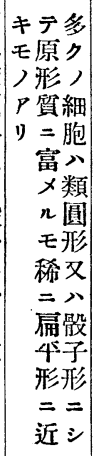 & 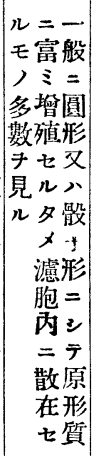 & 細 & 皮 \\
\hline $\begin{array}{l}\text { 淡圓 } \\
\text { 染形 } \\
\text { ス丈 } \\
\text { 類 } \\
\text { 圓 } \\
\text { 形 } \\
\text { チ } \\
\text { ナ } \\
\text { シ }\end{array}$ & $\begin{array}{l}\text { 淡圓 } \\
\text { 染形 } \\
\text { ^又 } \\
\text { 公 } \\
\text { 楕 } \\
\text { 圓 } \\
\text { 形 } \\
\text { f } \\
\text { ナ } \\
\text { シ }\end{array}$ & $\begin{array}{c}\text { 一圓 } \\
\text { 般形 } \\
=\text { 又 } \\
\text { 淡 } \\
\text { 染楕 } \\
\text { 性圓 } \\
\text { ナ形 } \\
\text { リ } \\
\text { シ } \\
\text { テ }\end{array}$ & 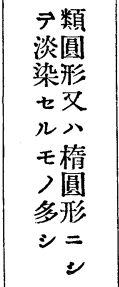 & 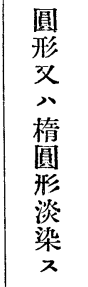 & 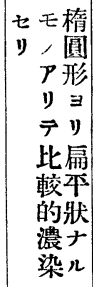 & $\begin{array}{c}\text { 焱圓 } \\
\text { 染形 } \\
\text { 又文 } \\
\text { 和 } \\
\text { 楕 } \\
\text { 圓 } \\
\text { 形 } \\
= \\
\text { シ } \\
\text { テ }\end{array}$ & 細 & 胞 \\
\hline $\begin{array}{l}\text { 充 } \\
\text { 盈 } \\
\text { 著 } \\
\text { シ }\end{array}$ & $\begin{array}{l}\text { 充 } \\
\text { 盈 } \\
\text { 著 } \\
\text { 明 }\end{array}$ & $\begin{array}{l}\text { 充 } \\
\text { 盈 } \\
\text { 著 } \\
\text { 晋 }\end{array}$ & $\begin{array}{l}\text { 充 } \\
\text { 盈 } \\
\text { 著 } \\
\text { 明 }\end{array}$ & $\begin{array}{l}\text { 充 } \\
\text { 盈 } \\
\text { 曐 } \\
\text { 明 }\end{array}$ & $\begin{array}{c}\text { 差對 } \\
\text { ナ照 } \\
\text { シ } \\
\text { 大 }\end{array}$ & $\begin{array}{l}\text { 充 } \\
\text { 盈 } \\
\text { 著 } \\
\text { 明 }\end{array}$ & & 管 \\
\hline $\begin{array}{l}\text { 變 } \\
\text { 华 } \\
ナ \\
\text { シ }\end{array}$ & $\begin{array}{l}\text { 變 } \\
\text { 化 } \\
\text { 子 } \\
\text { シ }\end{array}$ & $\begin{array}{l}\text { 變 } \\
\text { 华 } \\
\text { ナ } \\
\text { ə }\end{array}$ & $\begin{array}{l}\text { 變 } \\
\text { 化 } \\
\text { ナ } \\
\text { シ }\end{array}$ & $\begin{array}{l}\text { 變 } \\
\text { 化 } \\
\text { ナ } \\
\text { シ }\end{array}$ & $\begin{array}{l}\text { 變 } \\
\text { 化 } \\
\text { ナ } \\
\text { シ }\end{array}$ & $\begin{array}{l}\text { 變 } \\
\text { 华 } \\
+ \\
\text { シ }\end{array}$ & & 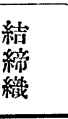 \\
\hline
\end{tabular}

\begin{tabular}{|c|c|}
\hline $11 \hat{f}$ & 10 우 \\
\hline $\begin{array}{c}\text { ナ對 } \\
\text { シ照 } \\
\text { ト } \\
\text { 大 } \\
\text { 差 }\end{array}$ & $\begin{array}{c}\text { ナ對 } \\
\text { シ照 } \\
\text { ト } \\
\text { 犬 } \\
\text { 差 }\end{array}$ \\
\hline 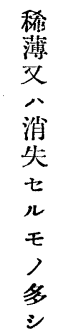 & 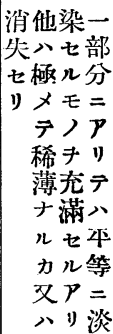 \\
\hline 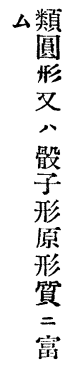 & 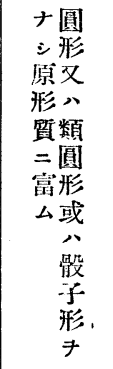 \\
\hline $\begin{array}{l}\text { 圓 } \\
\text { 形 } \\
\text { 父 } \\
\text { 敎 } \\
\text { 圓 } \\
\text { 形 } \\
\text { 淡 } \\
\text { 染 }\end{array}$ & $\begin{array}{l}\text { 圓 } \\
\text { 形 } \\
\text { 文 } \\
\text { ” } \\
\text { 楕 } \\
\text { 圓 } \\
\text { 形 } \\
\text { 淡 } \\
\text { 染 }\end{array}$ \\
\hline $\begin{array}{c}\text { ス请 } \\
\text { 明 } \\
\text { ナ } \\
\text { ラ }\end{array}$ & $\begin{array}{l}\text { 充 } \\
\text { 怒 } \\
\text { 著 } \\
\text { シ }\end{array}$ \\
\hline $\begin{array}{l}\text { 卛 } \\
\text { 化 } \\
\text { む } \\
\text { シ }\end{array}$ & $\begin{array}{l}\text { 變 } \\
\text { 化 } \\
\text { ナ } \\
\text { シ }\end{array}$ \\
\hline
\end{tabular}




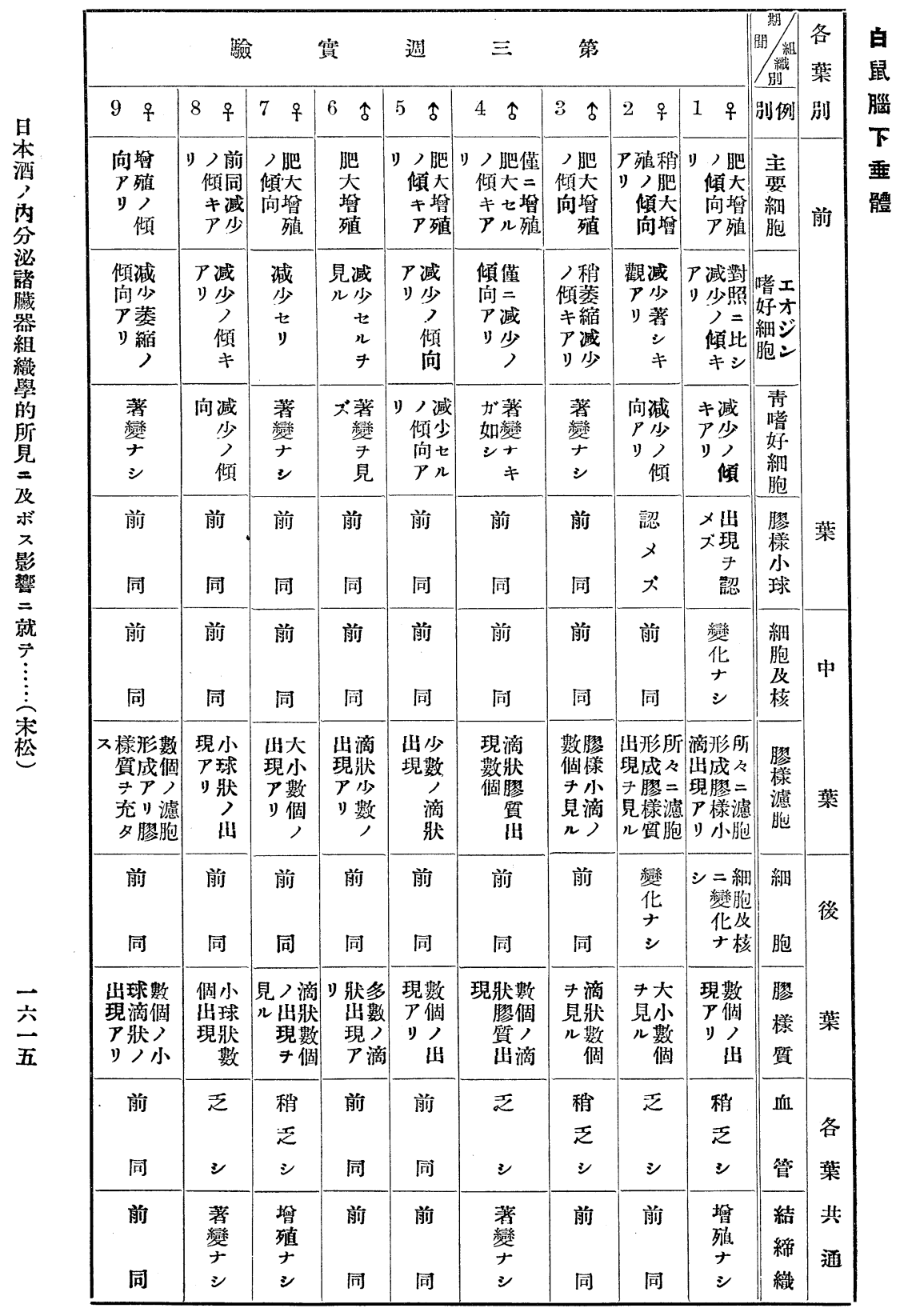




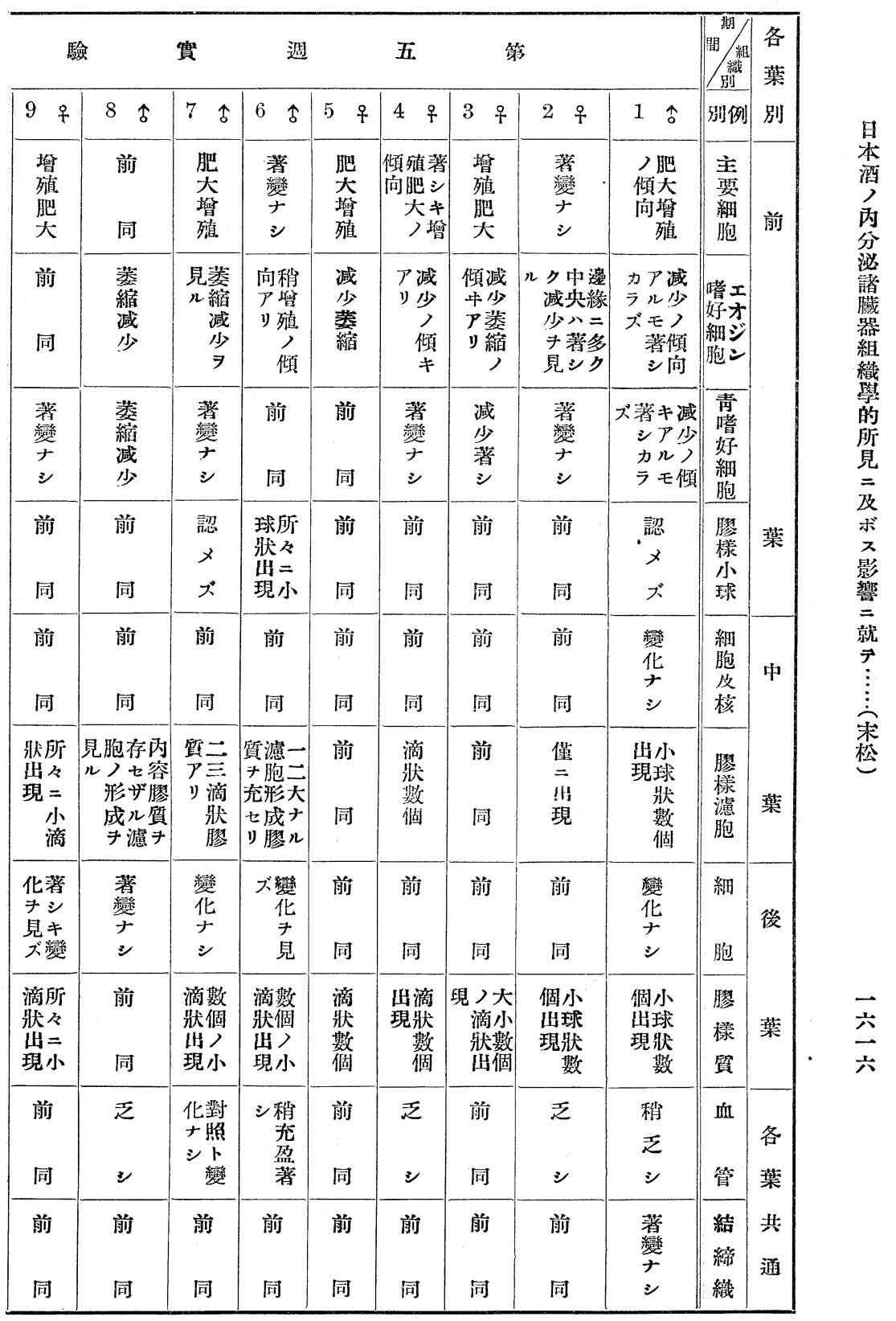




\begin{tabular}{|c|c|c|c|c|c|c|c|c|}
\hline & 噞 & 實 & 週 & $七$ & 第 & & 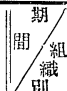 & $\begin{array}{l}\text { 各 } \\
\text { 葉 }\end{array}$ \\
\hline 7 古 & 6 우 & 5 今 & 4 우 & 3 ㅇ & 2 우 & $1 \hat{\delta}$ & 别例 & 別 \\
\hline $\begin{array}{l}\text { 增 } \\
\text { 殖 } \\
\text { ス }\end{array}$ & 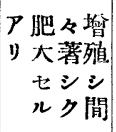 & $\begin{array}{l}\text { 前 } \\
\text { 同 }\end{array}$ & $\begin{array}{l}\text { 前 } \\
\text { 同 }\end{array}$ & $\begin{array}{l}\text { 向算 } \\
\text { P殖 } \\
\text { y年 } \\
\text { 傾 }\end{array}$ & $\begin{array}{l}\text { 肥 } \\
\text { 大 } \\
\text { 增 } \\
\text { 殖 }\end{array}$ & $\begin{array}{l}\text { 竲 } \\
\text { 殖 } \\
\text { 著 } \\
\text { 明 }\end{array}$ & $\begin{array}{l}\text { 主 } \\
\text { 喓 } \\
\text { 細 } \\
\text { 胞 }\end{array}$ & 前 \\
\hline $\begin{array}{l}\text { 减 } \\
\text { 少 } \\
\text { 著 } \\
\text { 到 }\end{array}$ & $\begin{array}{l}\text { リシ减 } \\
\text { キ少 } \\
\text { 觀穧 } \\
\text { ア著 }\end{array}$ & $\begin{array}{l}\text { キ蒌 } \\
\text { 見纙 } \\
\text { 几減 } \\
\text { 少 }\end{array}$ & $\begin{array}{l}\text { リナ减 } \\
\text { ル少 } \\
\text { 觀惹 } \\
\text { ア }\end{array}$ & \begin{tabular}{|l} 
シ减 \\
少 \\
秒 \\
著
\end{tabular} & $\begin{array}{l}\text { 向减 } \\
\text { P少 } \\
\text { リ傾 }\end{array}$ & 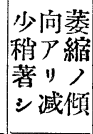 & 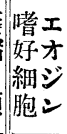 & \\
\hline $\begin{array}{l}\text { 傾㮐 } \\
\text { 向减 } \\
P \text { 少 } \\
y ノ\end{array}$ & $\begin{array}{l}\text { キ减 } \\
\text { P少 } \\
\text { リ年 } \\
\text { 傾 }\end{array}$ & 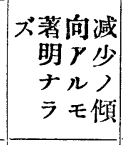 & $\begin{array}{l}\text { 前 } \\
\text { 同 }\end{array}$ & $\begin{array}{l}\text { キ减 } \\
\text { ア少 } \\
\text { 》) } \\
\text { 傾 }\end{array}$ & $\begin{array}{l}\text { 著 } \\
\text { 戀 } \\
\text { ナ } \\
\text { シ }\end{array}$ & $\begin{array}{c}\text { 向减 } \\
\text { 少 } \\
\text { 傾 }\end{array}$ & $\begin{array}{l}\text { 麦 } \\
\text { 嗜 } \\
\text { 好 } \\
\text { 細 } \\
\text { 胞 }\end{array}$ & \\
\hline $\begin{array}{l}\text { 前 } \\
\text { 同 }\end{array}$ & $\begin{array}{l}\text { 認 } \\
メ \\
\text { ズ }\end{array}$ & $\begin{array}{l}\text { ノ球三 } \\
\text { F狀三 } \\
\text { 見ノ, } \\
ル モ \text { 小 }\end{array}$ & $\begin{array}{l}\text { 出 } \\
\text { 現 } \\
ナ \\
\vdots\end{array}$ & $\begin{array}{c}\text { ア球二 } \\
\text { リ牀三 } \\
\text { 出 } \\
\text { 現小 }\end{array}$ & 同 & \begin{tabular}{l} 
出 \\
現 \\
\multirow{2}{*}{} \\
シ
\end{tabular} & $\begin{array}{l}\text { 膠 } \\
\text { 栐 } \\
\text { 小 } \\
\text { 球 }\end{array}$ & 菜 \\
\hline 同 & 同 & $\begin{array}{l}\text { 前 } \\
\text { 同 }\end{array}$ & $\begin{array}{l}\text { 前 } \\
\text { 同 }\end{array}$ & $\begin{array}{l}\text { 前 } \\
\text { 同 }\end{array}$ & $\begin{array}{l}\text { 前 } \\
\text { 同 }\end{array}$ & $\begin{array}{l}\text { 著 } \\
\text { 戀 } \\
\text { ナ } \\
\text { シ }\end{array}$ & $\begin{array}{l}\text { 細 } \\
\text { 胞 } \\
\text { 及 } \\
\text { 核 }\end{array}$ & 中 \\
\hline $\begin{array}{l}\text { 前 } \\
\text { 同 }\end{array}$ & $\begin{array}{l}\text { 認 } \\
メ \\
\text { ズ }\end{array}$ & $\begin{array}{l}\text { ノ成モ可 } \\
\text { 滴所ノナ } \\
\text { 牀々ンy } \\
\text { 出二濾夫 } \\
\text { 現數胞ナ } \\
\text { 個形几 }\end{array}$ & $\begin{array}{c}\text { 現所 } \\
P 乏 \\
\text { リ } \\
\text { 滴 } \\
\text { 狀 } \\
\text { 出 }\end{array}$ & 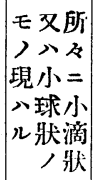 & $\begin{array}{l}\text { 現三 } \\
\text { P三 } \\
\text { リ } \\
\text { 滴 } \\
\text { 牀 } \\
\text { 出 }\end{array}$ & $\begin{array}{l}\text { 峴 } \\
\text { 足 } \\
\text { シ }\end{array}$ & $\begin{array}{l}\text { 膠 } \\
\text { 栐 } \\
\text { 濾 } \\
\text { 胞 }\end{array}$ & 葉 \\
\hline $\begin{array}{l}\text { 前 } \\
\text { 同 }\end{array}$ & $\begin{array}{l}\text { 前 } \\
\text { 同 }\end{array}$ & 前 & $\begin{array}{l}\text { 前 } \\
\text { 同 }\end{array}$ & $\begin{array}{l}\text { 前 } \\
\text { 同 }\end{array}$ & $\begin{array}{l}\text { 前 } \\
\text { 同 }\end{array}$ & $\begin{array}{l}\text { 蔁 } \\
\text { 變 } \\
\text { ナ } \\
\text { シ }\end{array}$ & $\begin{array}{l}\text { 細 } \\
\text { 胞 }\end{array}$ & 後 \\
\hline $\begin{array}{l}\text { 現滴所 } \\
P \text { 牀々 } \\
\text { リ }= \\
\text { 山小 }\end{array}$ & $\begin{array}{l}\text { 見狀少 } \\
\text { ルナ數 } \\
\text { ル小 } \\
\text { チ滴 }\end{array}$ & 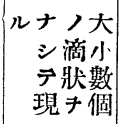 & $\begin{array}{l}\text { ア小所 } \\
\text { 滴 \& } \\
\text { 出 } \\
\text { 現大 }\end{array}$ & $\begin{array}{l}\supset \text { 滴所 } \\
\text { 牀 } \\
\text { 見ノ= } \\
ル モ \text { 小 }\end{array}$ & $\begin{array}{l}\text { リ狀所 } \\
\text { 岑々 } \\
\text { 現= } \\
\text { ア滴 }\end{array}$ & 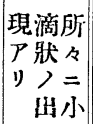 & $\begin{array}{l}\text { 膠 } \\
\text { 樣 } \\
\text { 質 }\end{array}$ & 葉 \\
\hline $\begin{array}{l}\text { 前 } \\
\text { 同 }\end{array}$ & 乏 & $\begin{array}{l}\text { 稍 } \\
乏 乏 \\
\text { 之 }\end{array}$ & $\begin{array}{l}\text { 卜殆 } \\
\text { 同 } \\
\text { 澲 } \\
\text { 䡒 }\end{array}$ & 前 & 天 & 乏 & $\begin{array}{l}\text { 血 } \\
\text { 管 }\end{array}$ & $\begin{array}{l}\text { 各 } \\
\text { 葉 }\end{array}$ \\
\hline 前 & 前 & 前 & 前 & 前 & $\begin{array}{l}\text { 變 } \\
\text { 华 } \\
ナ \\
\text { シ }\end{array}$ & $\begin{array}{l}\text { 著 } \\
\text { 變 } \\
\text { ナ } \\
\text { シ }\end{array}$ & $\begin{array}{l}\text { 結 } \\
\text { 締 } \\
\text { 織 }\end{array}$ & $\begin{array}{l}\text { 共 } \\
\text { 通 }\end{array}$ \\
\hline
\end{tabular}

\begin{tabular}{|c|c|}
\hline 11 占 & 10 우 \\
\hline 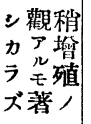 & $\begin{array}{l}\text { 前 } \\
\text { 同 }\end{array}$ \\
\hline $\begin{array}{l}\text { 著 } \\
\text { 變 } \\
\text { ナ } \\
\text { シ }\end{array}$ & $\begin{array}{l}\text { 减 } \\
\text { 少 }\end{array}$ \\
\hline 前 & 前 \\
\hline 同 & 同 \\
\hline ナ & 前 \\
\hline シ & 同 \\
\hline 前 & 前 \\
\hline 同 & 同 \\
\hline $\begin{array}{l}\text { 出 } \\
\text { 現 } \\
\text { ナ }\end{array}$ & 前 \\
\hline シ & 同 \\
\hline $\begin{array}{l}\text { 變 } \\
\text { 华 } \\
+ \\
\text { シ }\end{array}$ & $\begin{array}{l}\text { 變 } \\
\text { 變 } \\
\text { ナ } \\
\text { シ }\end{array}$ \\
\hline 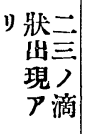 & 同 \\
\hline $\begin{array}{l}\text { 戀 } \\
\text { 华 } \\
\text { ナ } \\
\text { シ }\end{array}$ & 前 \\
\hline $\begin{array}{l}\text { 變 } \\
\text { 化 } \\
⿱ \\
シ \\
\dot{⿰}\end{array}$ & 同 \\
\hline
\end{tabular}




\begin{tabular}{|c|c|c|c|c|c|c|c|c|c|c|}
\hline \multicolumn{2}{|c|}{ 噞 } & 週 & 五 & 第 & 噞 & \multicolumn{2}{|c|}{ 實 週 三 } & 第 & 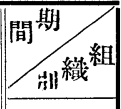 & $\begin{array}{l}\text { 白 } \\
\text { 鼠 }\end{array}$ \\
\hline $11 \hat{\delta}$ & 8 占 & $7 \hat{8}$ & 6 占 & $1 \hat{\delta}$ & $6 \uparrow$ & $5 \quad \hat{~}$ & 4 占 & 3 占 & 別 例 & 睪 $\quad$ 日 \\
\hline 前 & 前 & $\begin{array}{l}\text { 前 } \\
\text { 同 }\end{array}$ & $\begin{array}{l}\text { 前 } \\
\text { 同 }\end{array}$ & $\begin{array}{l}\text { 著 } \\
\text { 變 } \\
\text { ナ } \\
\text { シ }\end{array}$ & $\begin{array}{l}\text { 前 } \\
\text { 同 }\end{array}$ & $\begin{array}{l}\text { 前 } \\
\text { 同 }\end{array}$ & $\begin{array}{l}\text { 著 } \\
\text { 變 } \\
ナ \\
\text { シ }\end{array}$ & $\begin{array}{l}\text { 變對 } \\
\text { ナ照 } \\
\text { シ } \\
\text { 著 }\end{array}$ & $\begin{array}{l}\text { 細 } \\
\text { 精 } \\
\text { 管 }\end{array}$ & 丸 $\begin{array}{c}\text { 本 } \\
\text { 酒 } \\
\text { 分 } \\
\text { 分 }\end{array}$ \\
\hline $\begin{array}{l}\text { 晴 } \\
\text { 變 } \\
ナ \\
\text { シ }\end{array}$ & $\begin{array}{l}\text { 成レキ間 } \\
\text { 著ド見々 } \\
\text { シモザ全 } \\
\text { キ多ル然 } \\
\text { ヨクモ其 } \\
\text { 見ハノ形 } \\
\text { ル形ア成 }\end{array}$ & $\begin{array}{l}\text { シ配 } \\
\text { 列 } \\
\text { 整 } \\
\text { 然 } \\
\text { 變 } \\
\text { 性 } \\
\text { ナ }\end{array}$ & 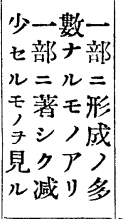 & $\begin{array}{l}\text { ル稀 } \\
\text { ア } \\
\text { リ形 } \\
\text { 成 } \\
\text { チ } \\
\text { 見 } \\
\text { サ }\end{array}$ & $\begin{array}{l}\text { 形 } \\
\text { 威 } \\
\text { 良 } \\
\text { 好 }\end{array}$ & $\begin{array}{l}\text { 多 } \\
\text { ク } \\
\text { 良 } \\
\text { 好 } \\
\text { † } \\
\text { リ }\end{array}$ & 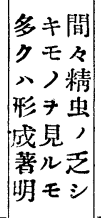 & $\begin{array}{l}\text { 著 } \\
\text { 變 } \\
+ \\
\text { シ }\end{array}$ & 精 & $\begin{array}{l}\text { 箸藏 } \\
\text { 器 } \\
\text { 縕 } \\
\text { 䁷 } \\
\text { 的 }\end{array}$ \\
\hline $\begin{array}{l}\text { 著 } \\
\text { 變 } \\
\text { ナ } \\
\text { シ }\end{array}$ & $\begin{array}{c}\text { レテ稀 } \\
\text { ル核二 } \\
\text { ア濃細 } \\
\text { リ染胞 } \\
\text { 性脫 } \\
\text { ト洛 } \\
\text { ナシ }\end{array}$ & $\begin{array}{l}\text { 變 } \\
\text { 华 } \\
\text { ナ } \\
\text { シ }\end{array}$ & 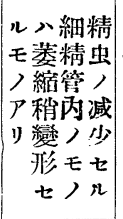 & 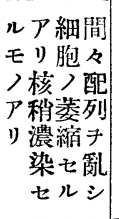 & $\begin{array}{l}\text { 著 } \\
\text { 變 } \\
\text { ナ } \\
\text { シ }\end{array}$ & $\begin{array}{c}\text { 部配 } \\
\text { 分列 } \\
\text { 不 } \\
\text { リ規 } \\
\text { 律 } \\
\text { ナ } \\
\text { ル }\end{array}$ & 同 & $\begin{array}{l}\text { 䓔 } \\
\text { 變 } \\
\text { 广 } \\
\text { シ }\end{array}$ & $\begin{array}{l}\text { 精 } \\
\text { 子 } \\
\text { 細 } \\
\text { 胞 }\end{array}$ & $\begin{array}{l}\text { 見 } \\
\text { 二 } \\
\text { 及 } \\
\text { ボ } \\
\text { 原 } \\
\text { 影 } \\
\text { 幎 }\end{array}$ \\
\hline 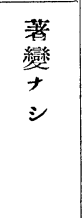 & 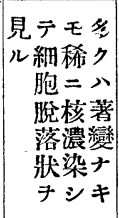 & $\begin{array}{l}\text { 著 } \\
\text { 變 } \\
\text { 見 } \\
\text { ズ }\end{array}$ & $\begin{array}{c}\text { 傾細 } \\
\text { キ胞 } \\
\text { ア核 } \\
\text { リ秽 } \\
\text { 濃 } \\
\text { 染 } \\
\text { ノ }\end{array}$ & 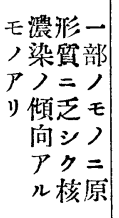 & $\begin{array}{l}\text { 著 } \\
\text { 變 } \\
\text { ナ } \\
\text { シ }\end{array}$ & $\begin{array}{c}\text { 向核 } \\
P \text { 稍 } \\
\text { リ濃 } \\
\text { 染 } \\
\text { 七 } \\
\text { n } \\
\text { 傾 }\end{array}$ & $\begin{array}{l}\text { 著 } \\
\text { 變 } \\
\text { ナ } \\
\text { シ }\end{array}$ & $\begin{array}{l}\text { 變 } \\
\text { 华 } \\
\text { ナ } \\
\text { シ }\end{array}$ & $\begin{array}{l}\text { 精 } \\
\text { 目 } \\
\text { 細 } \\
\text { 胞 }\end{array}$ & $\begin{array}{c}\bar{c} \\
\text { 就 } \\
\text { テ } \\
\vdots \\
\vdots \\
\text { 禾 } \\
\text { 松 }\end{array}$ \\
\hline $\begin{array}{l}\text { 前 } \\
\text { 同 }\end{array}$ & $\begin{array}{l}\text { 前 } \\
\text { 同 }\end{array}$ & $\begin{array}{l}\text { 變 } \\
\text { 华 } \\
ナ \\
\text { シ }\end{array}$ & \begin{tabular}{|l|} 
向染胞一 \\
P 七核部 \\
リ几秒〉 \\
倾濃細
\end{tabular} & $\begin{array}{l}\text { ナ殊 } \\
\text { シド } \\
\text { 著 } \\
\text { 變 }\end{array}$ & $\begin{array}{l}\text { 蓸 } \\
\text { 變 } \\
\text { ナ } \\
\text { シ }\end{array}$ & $\begin{array}{l}\text { 前 } \\
\text { 同 }\end{array}$ & $\begin{array}{l}\text { 前 } \\
\text { 同 }\end{array}$ & $\begin{array}{l}\text { 變 } \\
\text { 华 } \\
ナ \\
\text { シ }\end{array}$ & $\begin{array}{l}\text { 精 } \\
\text { 租 } \\
\text { 細 } \\
\text { 胞 }\end{array}$ & \\
\hline 前 & 同 & $\begin{array}{l}\text { 變 } \\
\text { 化 } \\
\text { ナ } \\
\text { シ }\end{array}$ & 同 & $\begin{array}{l}\text { 著 } \\
\text { 變 } \\
\text { ナ } \\
\text { シ }\end{array}$ & $\begin{array}{l}\text { 著 } \\
\text { 變 } \\
\text { ナ } \\
\text { シ }\end{array}$ & $\begin{array}{l}\text { 前 } \\
\text { 同 }\end{array}$ & $\begin{array}{l}\text { 前 } \\
\text { 问 }\end{array}$ & $\begin{array}{l}\text { 變 } \\
\text { 化 } \\
\text { ナ } \\
\text { シ }\end{array}$ & $\begin{array}{l}1 セ \\
\text { 氏ル } \\
\text { 細ト } \\
\text { 胞り }\end{array}$ & \\
\hline 同 & 同 & $\begin{array}{l}\text { 前 } \\
\text { 同 }\end{array}$ & $\begin{array}{l}\text { 變 } \\
\text { 化 } \\
+ \\
\text { シ }\end{array}$ & $\begin{array}{l}\text { ブ變 } \\
\text { 华 } \\
\text { 我 } \\
\text { 見 }\end{array}$ & $\begin{array}{l}\text { 溸 } \\
\text { 變 } \\
ナ \\
\text { シ }\end{array}$ & $\begin{array}{l}\text { 前 } \\
\text { 同 }\end{array}$ & $\begin{array}{l}\text { 前 } \\
\text { 同 }\end{array}$ & $\begin{array}{l}\text { 變 } \\
\text { 化 } \\
\text { ナ } \\
\text { シ }\end{array}$ & $\begin{array}{l}\text { 間 } \\
\text { 細 } \\
\text { 胞 }\end{array}$ & 六 \\
\hline $\begin{array}{l}\text { 變 } \\
\text { 华 } \\
\text { ナ } \\
\text { シ }\end{array}$ & $\begin{array}{l}\text { 稍 } \\
\text { 增 } \\
\text { 殖 } \\
\end{array}$ & $\begin{array}{l}\text { 稍 } \\
\text { 篮 } \\
\text { 殖 }\end{array}$ & 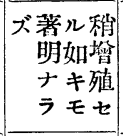 & $\begin{array}{l}\text { 稍 } \\
\text { 箸 } \\
\text { 殖 }\end{array}$ & 同 & 同 & 间 & $\begin{array}{l}\text { 變 } \\
\text { 华 } \\
\text { ナ } \\
\text { シ }\end{array}$ & $\begin{array}{l}\text { 結間 } \\
\text { 締 } \\
\text { 織啠買 }\end{array}$ & \\
\hline $\begin{array}{c}\text { 差對 } \\
+ \text { 照 } \\
\text { シ } \\
\text { 大 }\end{array}$ & $\begin{array}{l}\text { 稍 } \\
\text { 乏 } \\
\text { シ }\end{array}$ & $\begin{array}{l}\text { 變對 } \\
\text { ナ照 } \\
\text { シ } \\
\text { 著 }\end{array}$ & $\begin{array}{l}\text { 淞 } \\
\text { 乏 } \\
\text { ״ }\end{array}$ & $\begin{array}{l}\text { 觀稍 } \\
P 乏 \\
\text { リ } \\
\quad \neq\end{array}$ & 前 & $\begin{array}{l}\text { 變 } \\
\text { 化 } \\
ナ \\
\text { シ }\end{array}$ & 前 & $\begin{array}{l}\text { 秒 } \\
\text { 充 } \\
\text { 盈 } \\
\text { ス }\end{array}$ & $\begin{array}{l}\text { 血 } \\
\text { 管 }\end{array}$ & \\
\hline
\end{tabular}




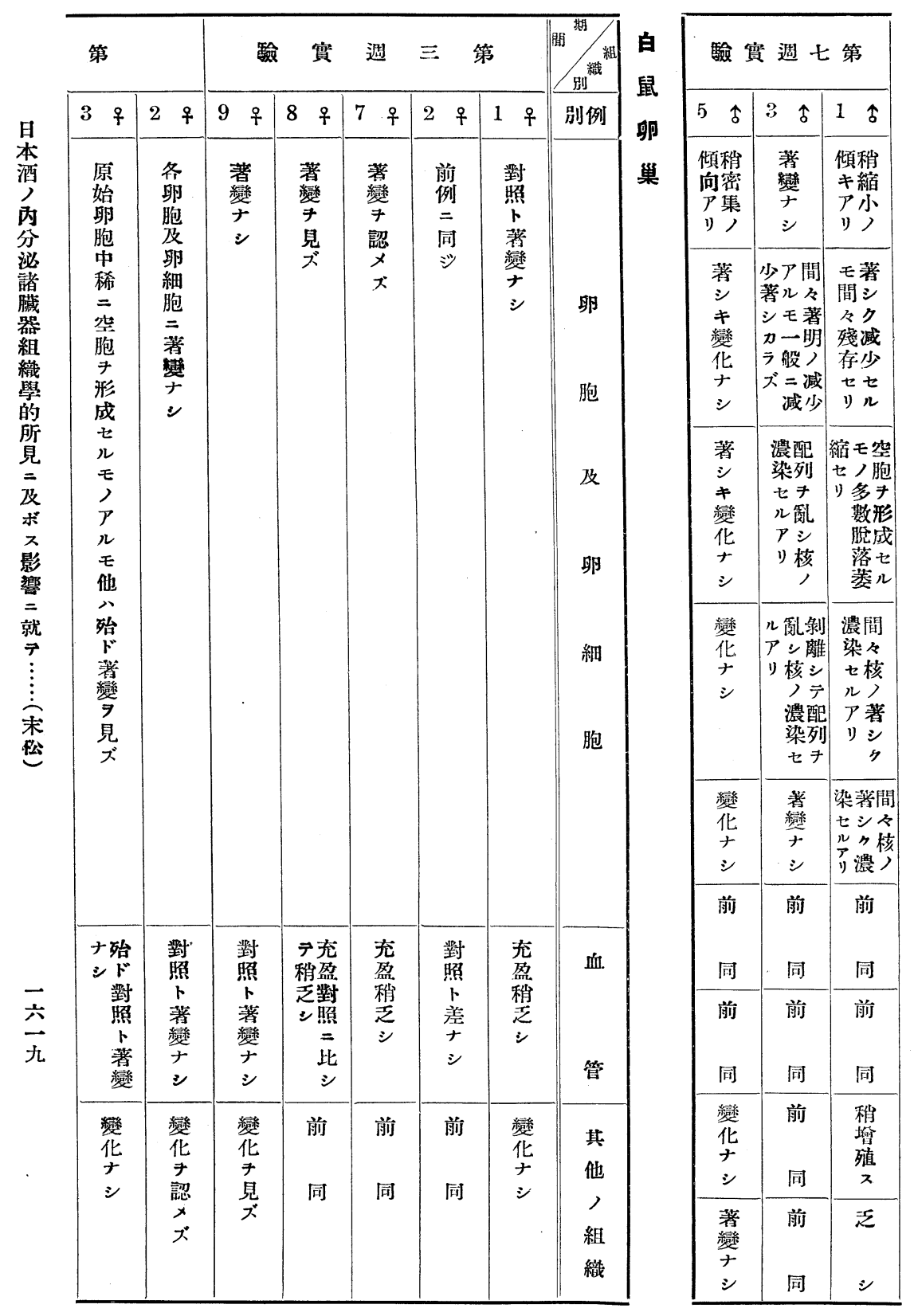




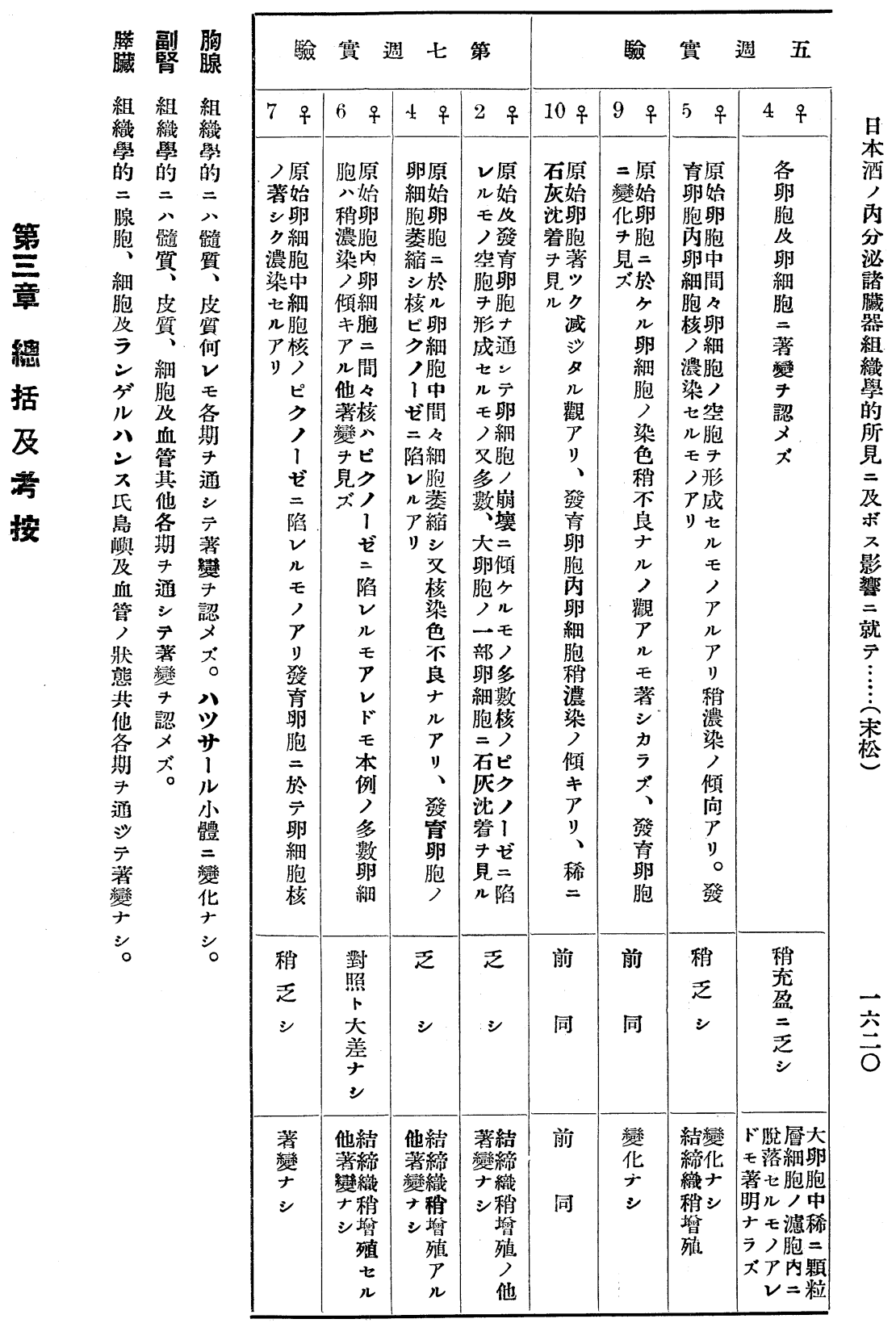




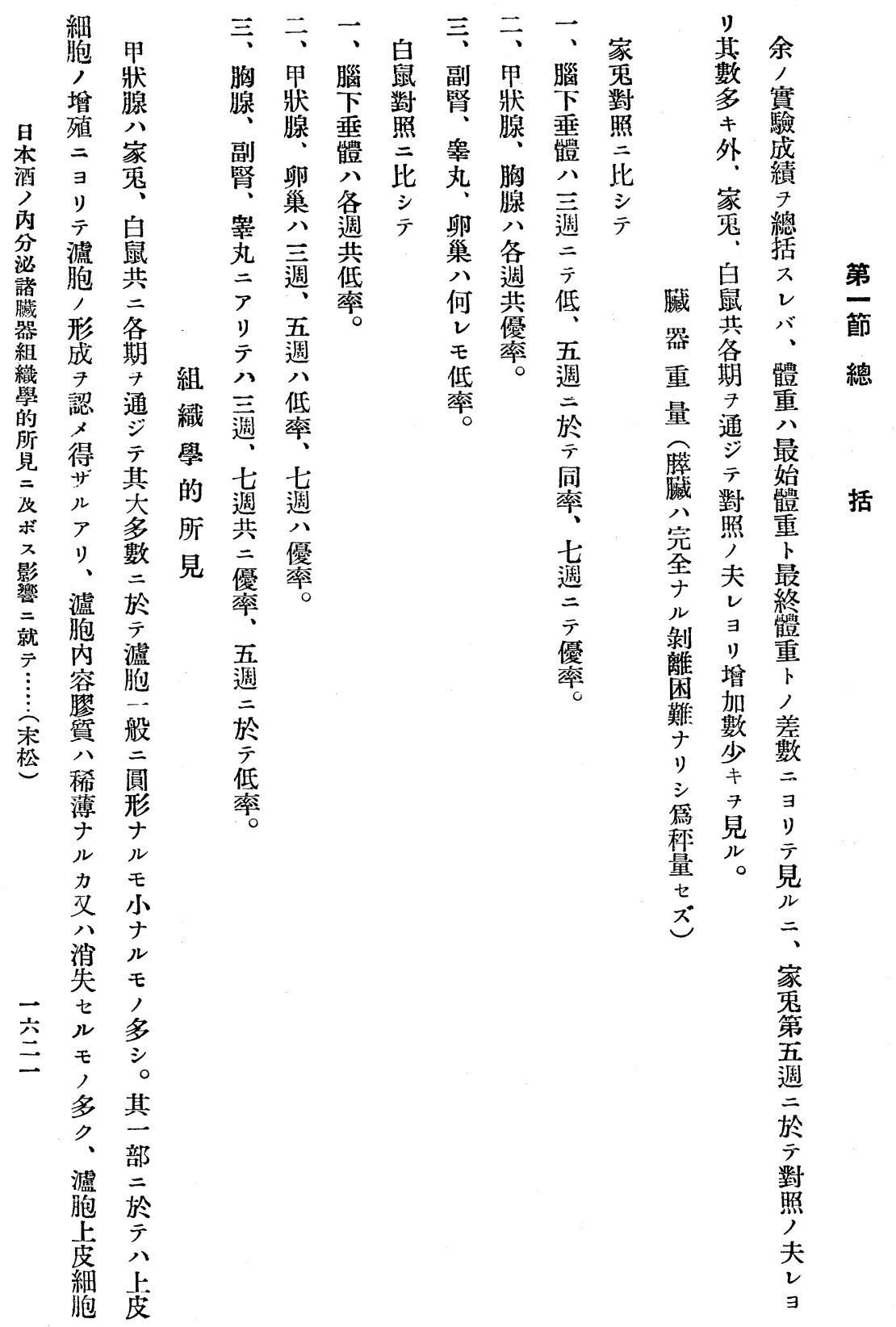




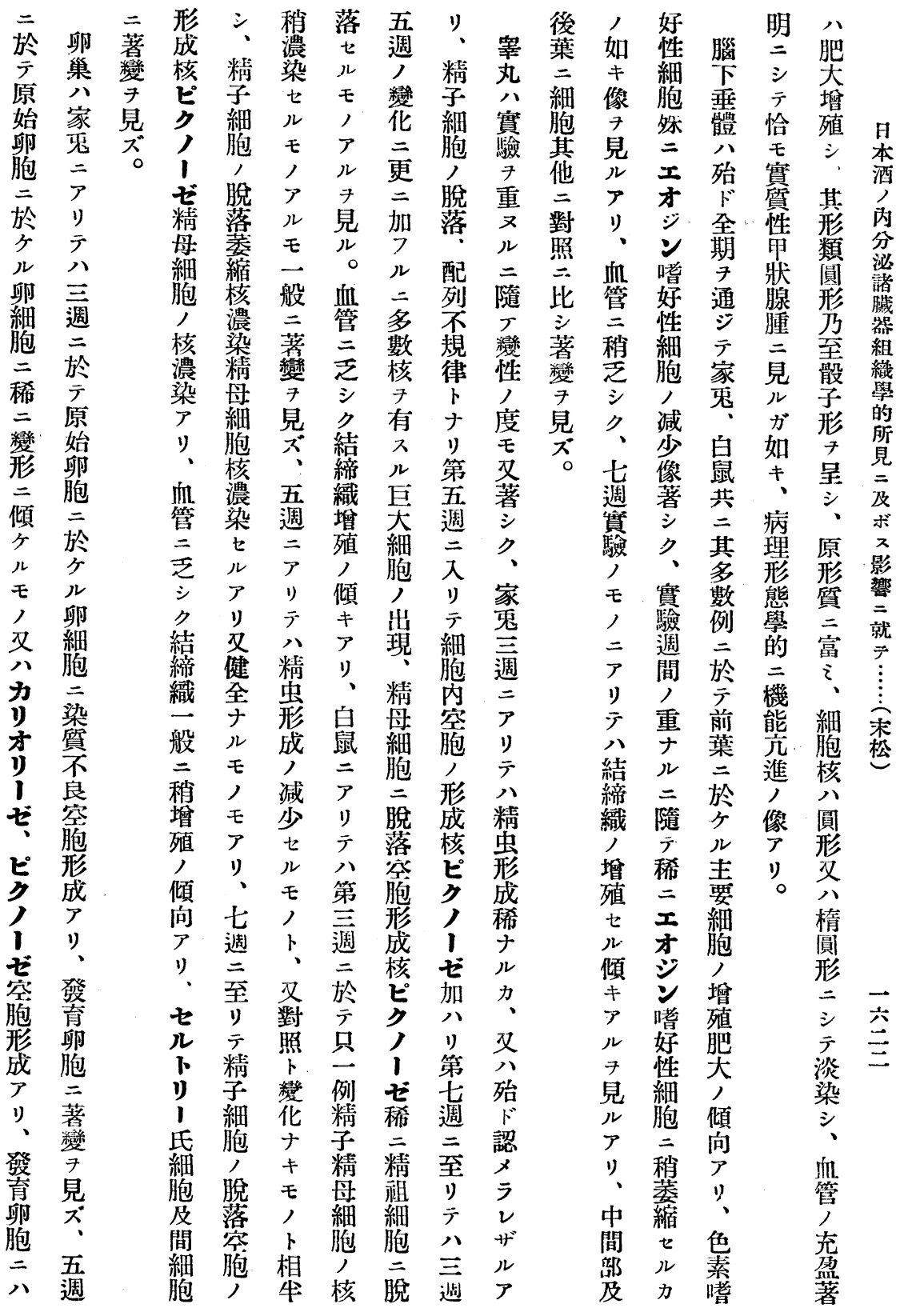



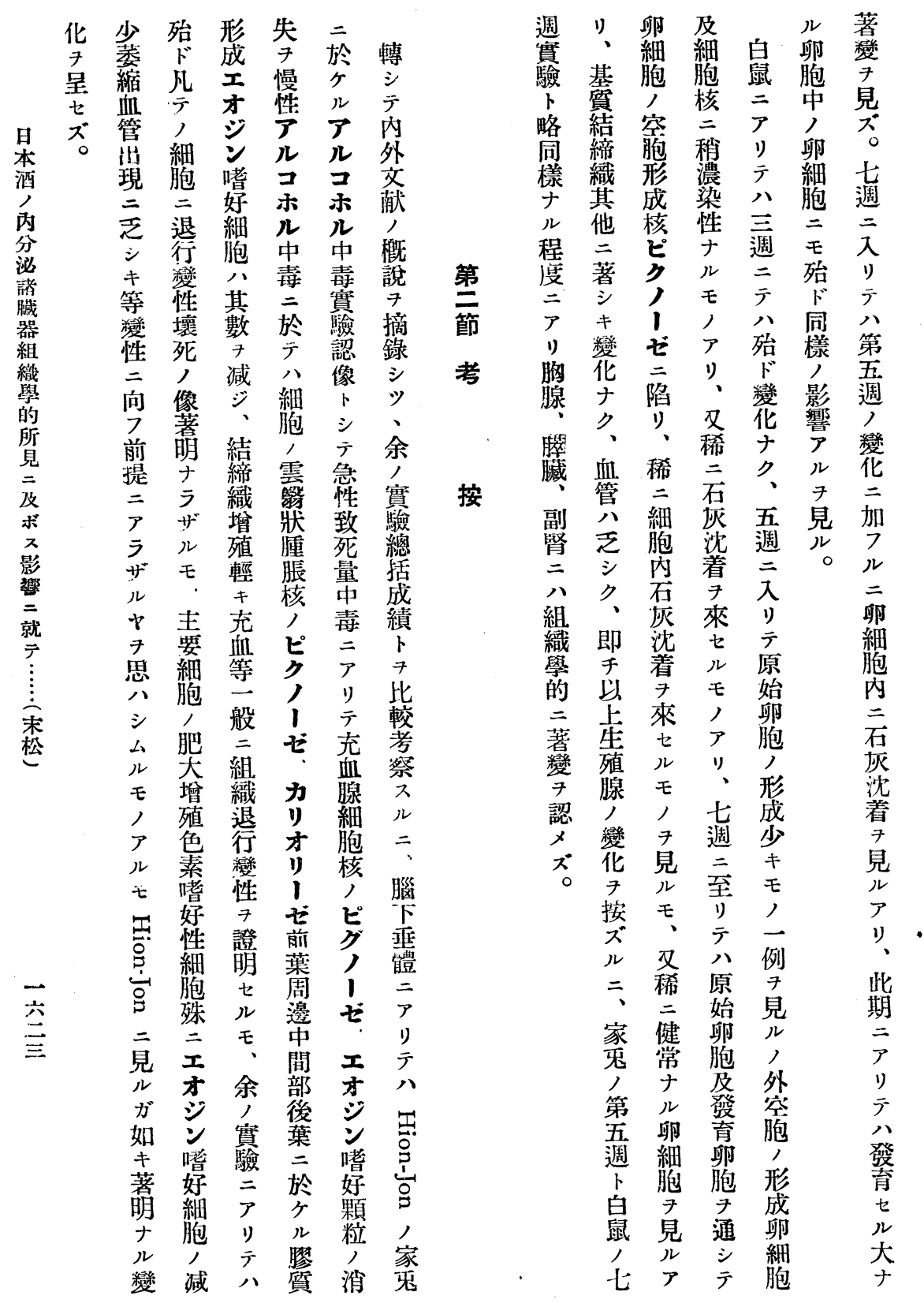


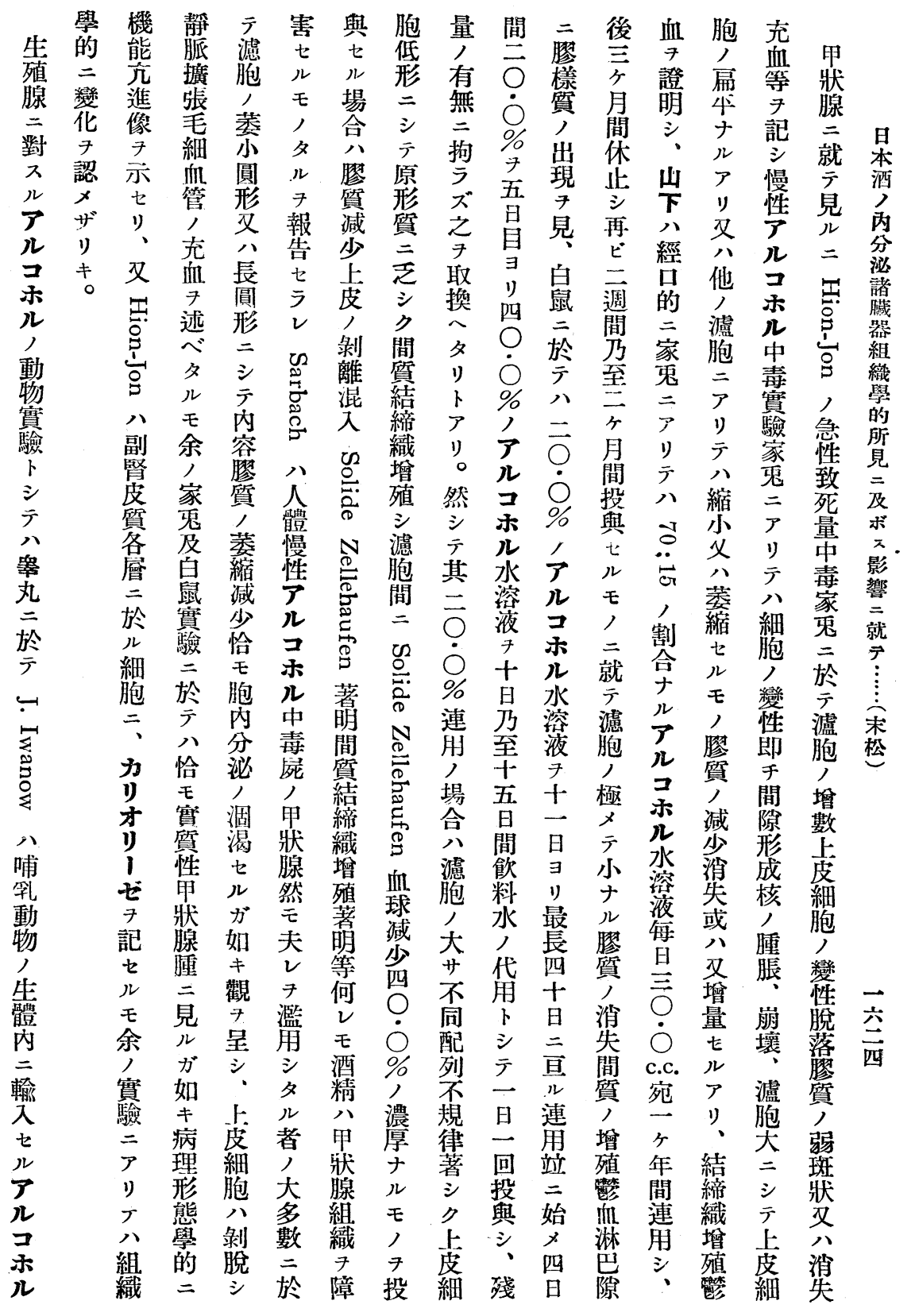




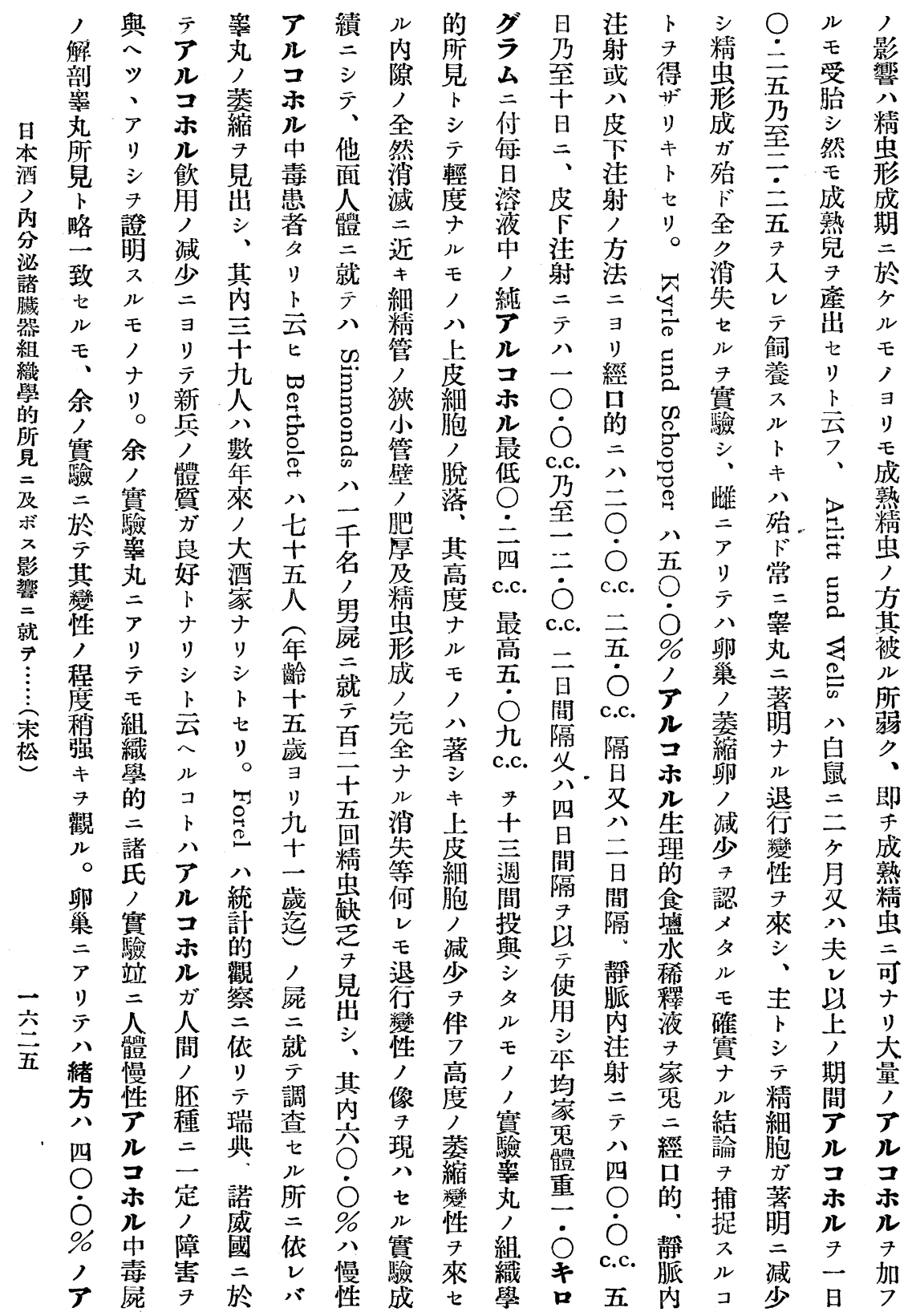




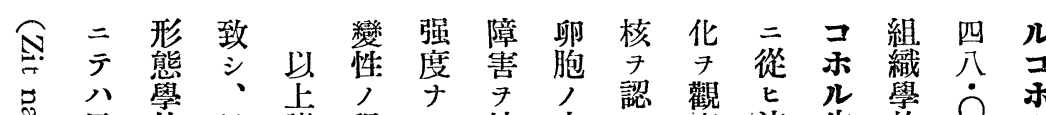

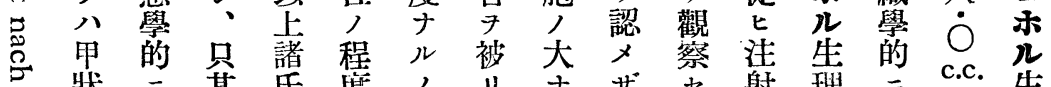

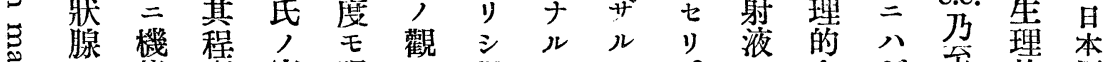

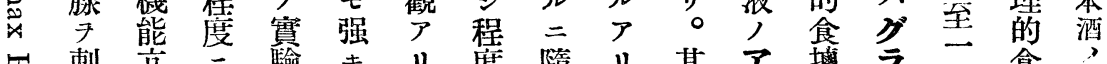

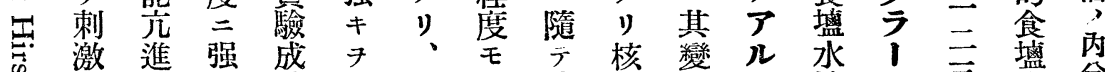

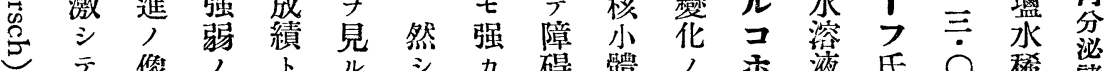

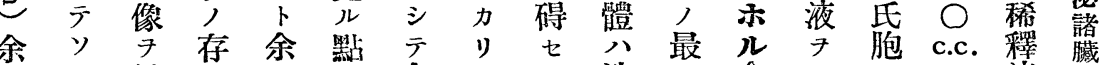

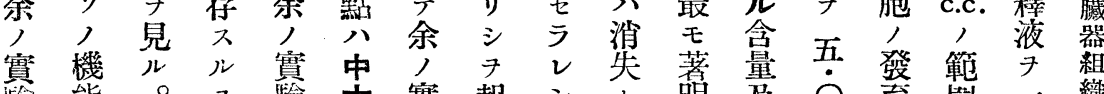

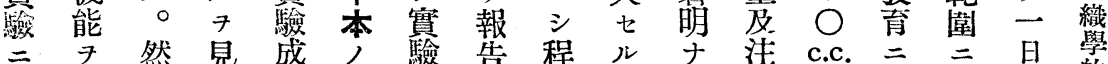

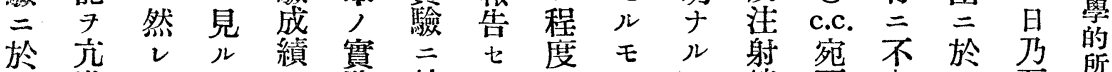
テ進ド, 占驗於り芦, 八總耳良方至䙿

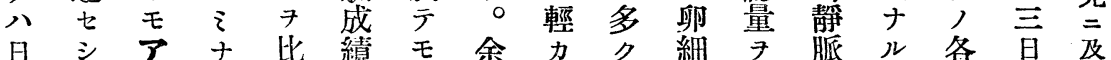

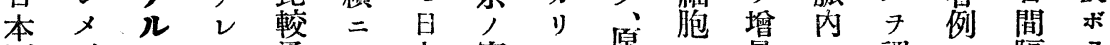

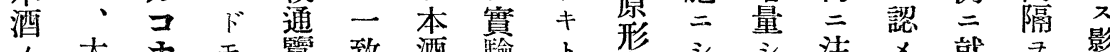

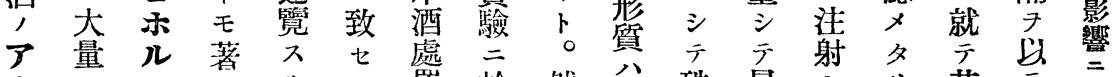

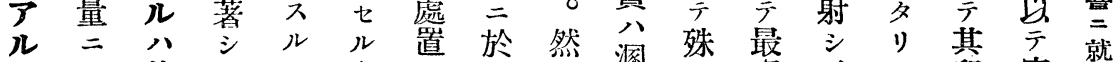
コテ他 $\neq=$ 處

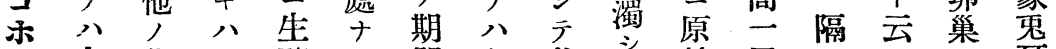

ル有化甲殖り間卯其葩始回日合正

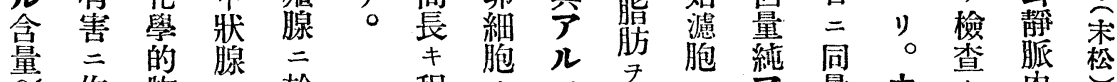

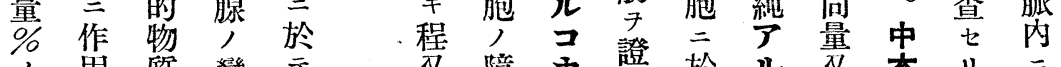

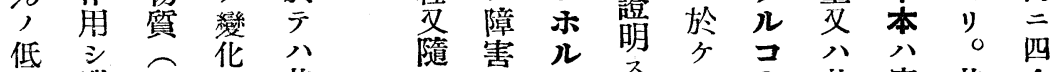

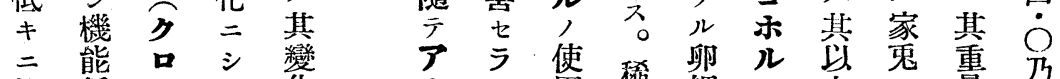

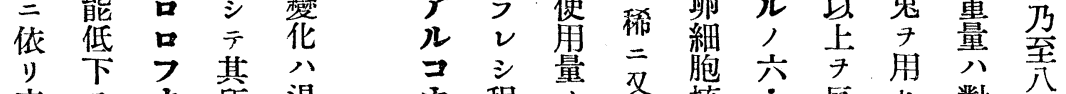

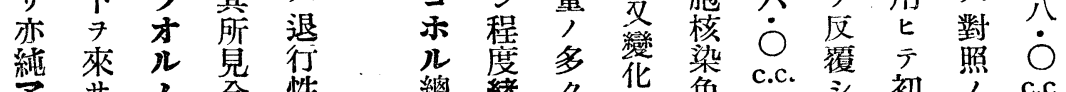

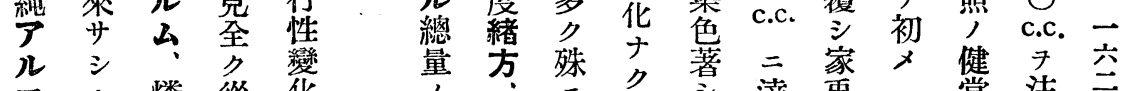

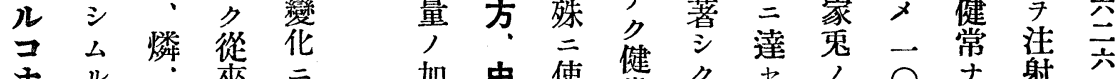

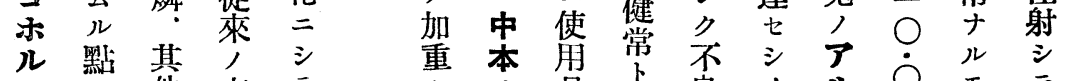

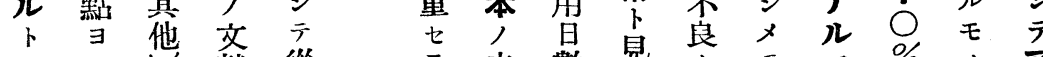

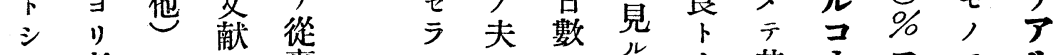

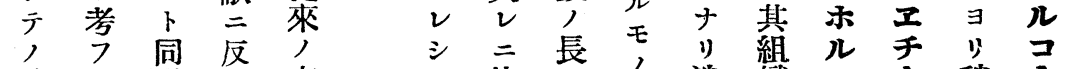
總 ル 榬 少八皇病三 程 


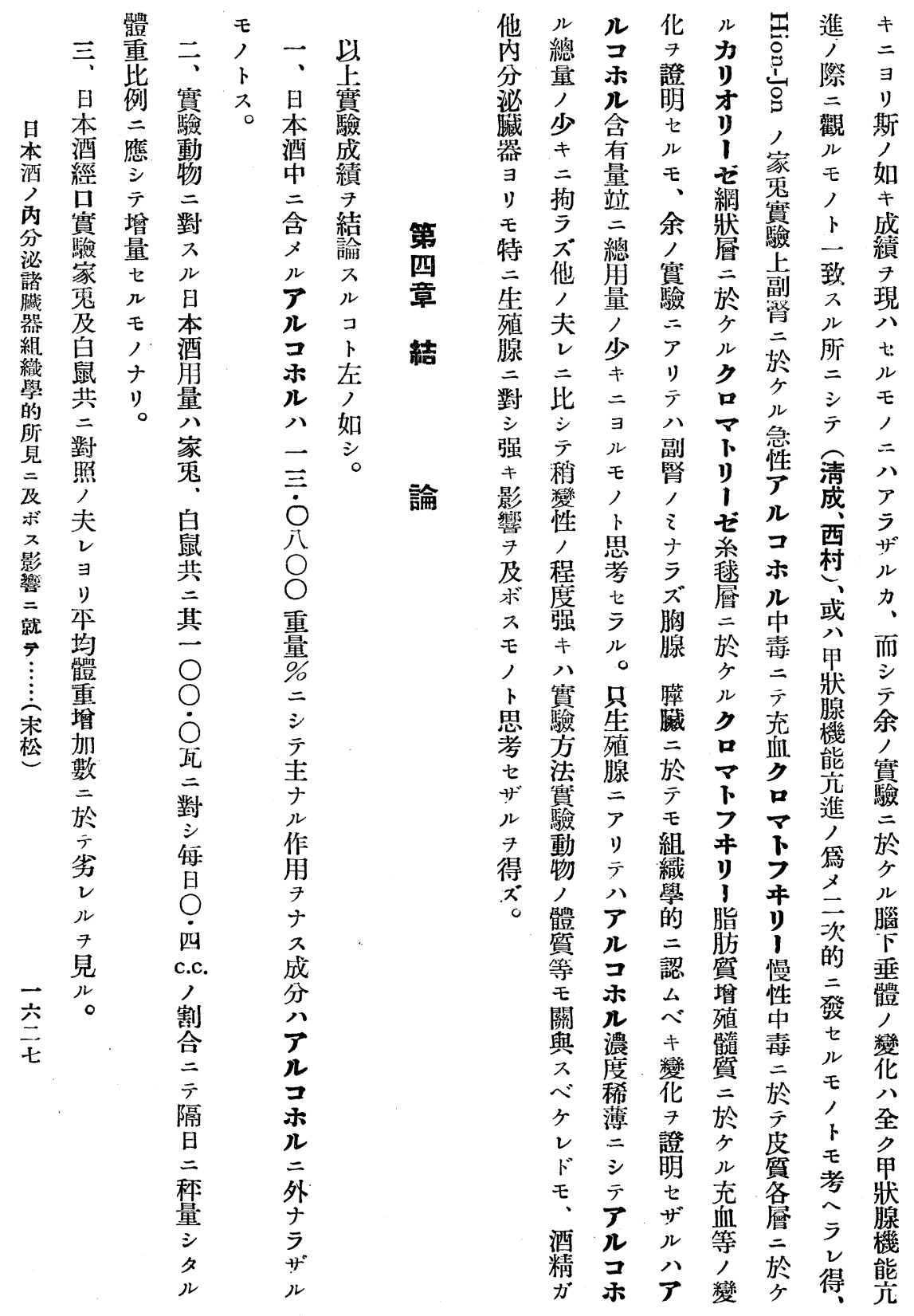




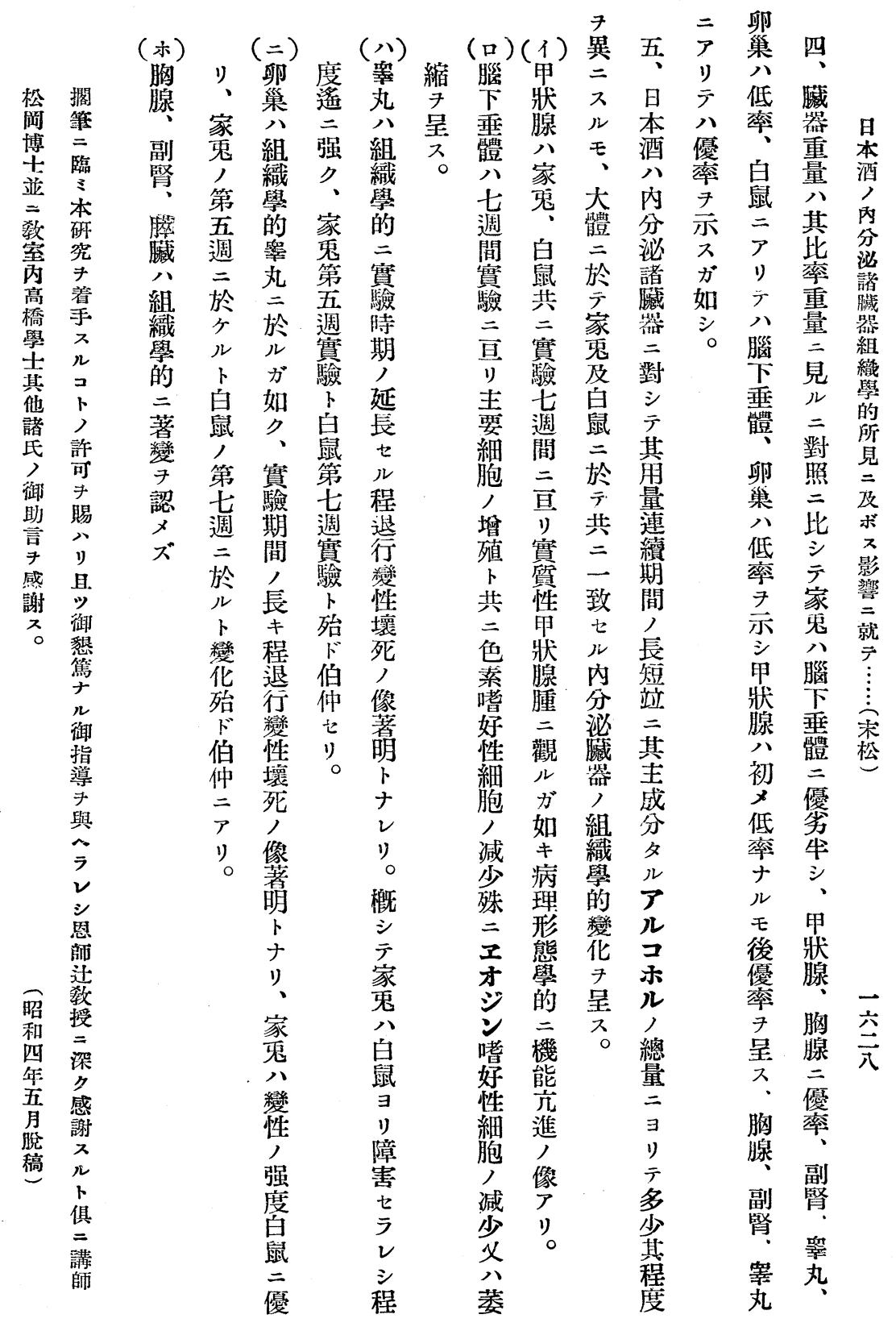




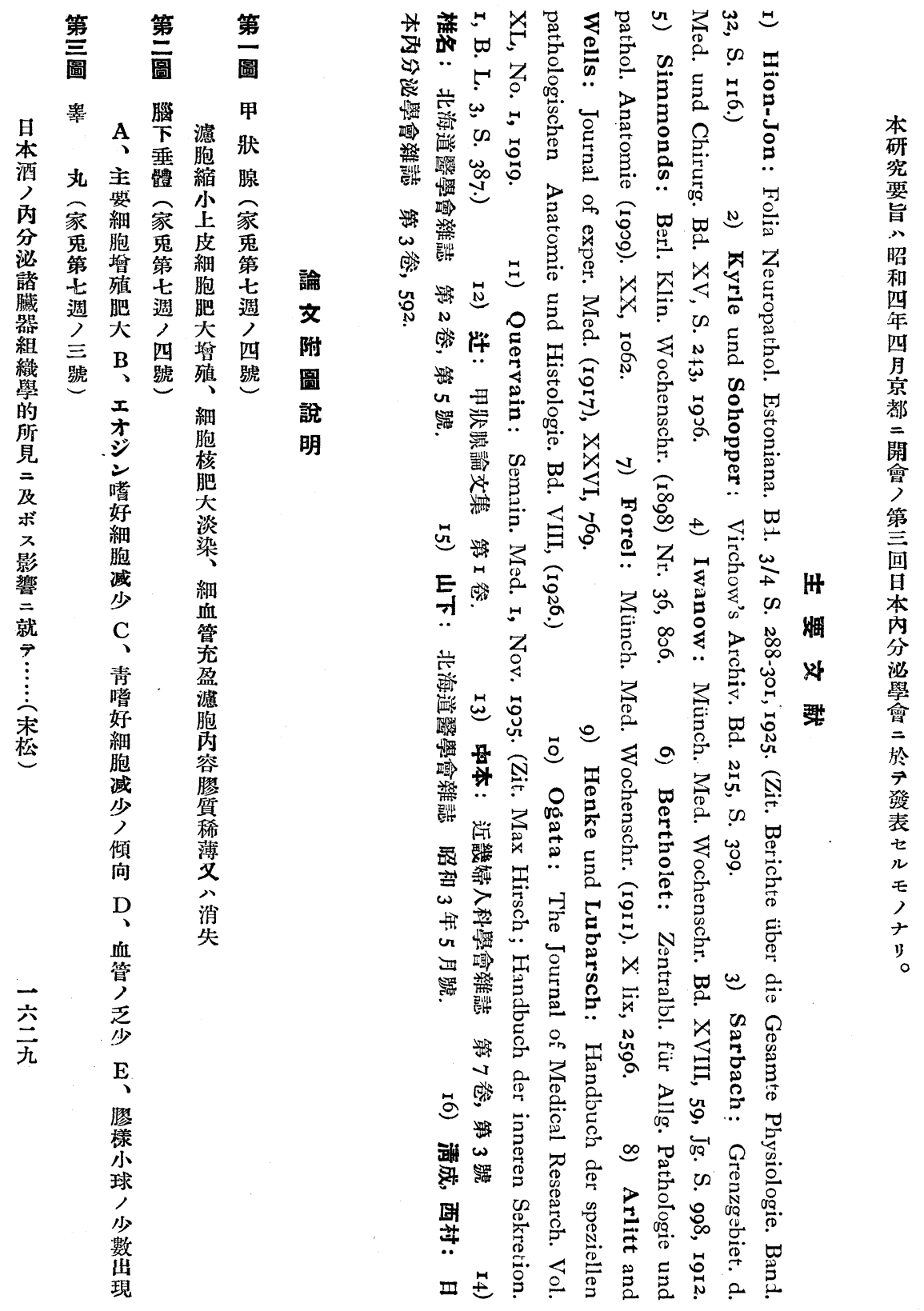




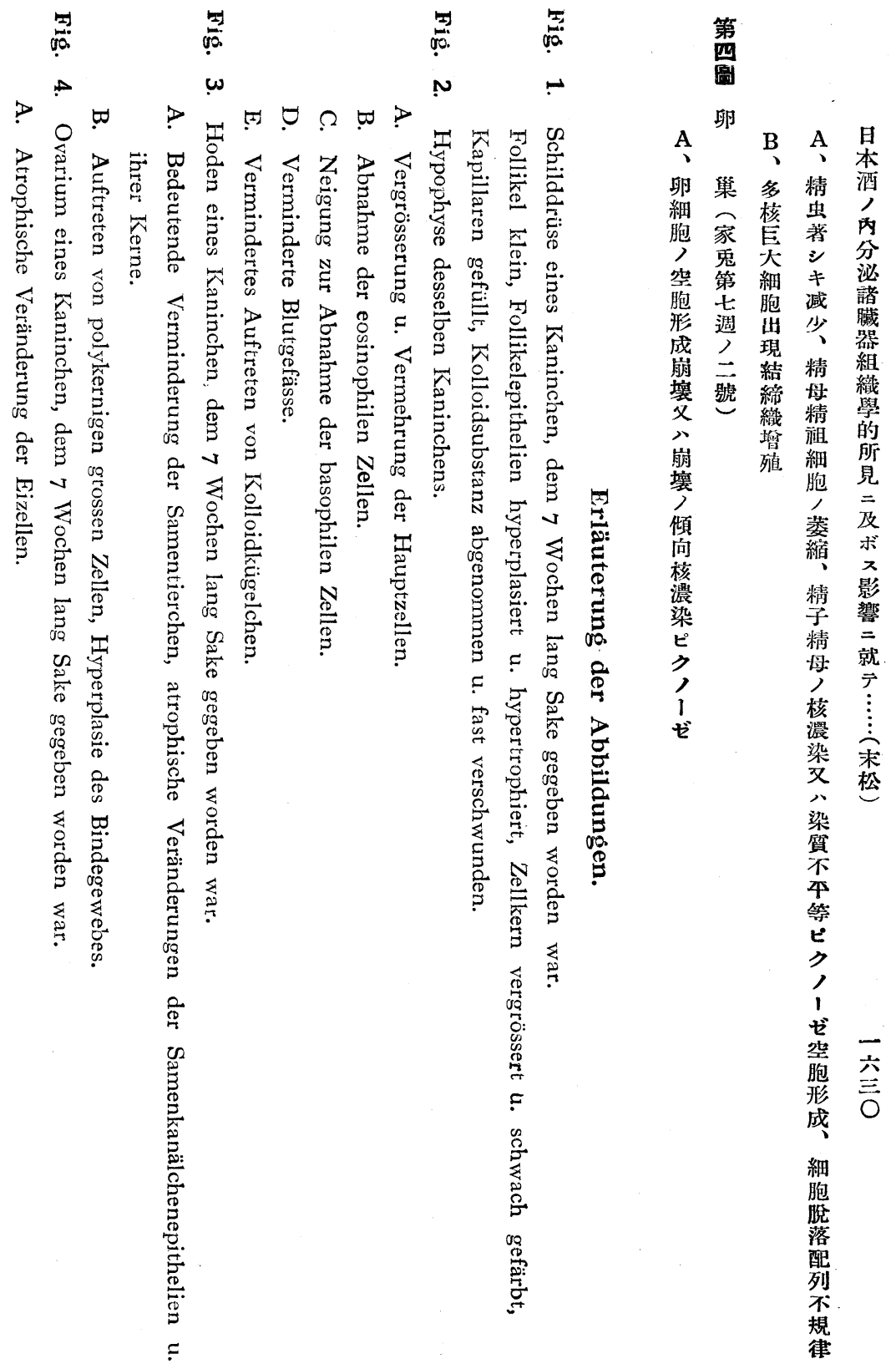


Fig. I.

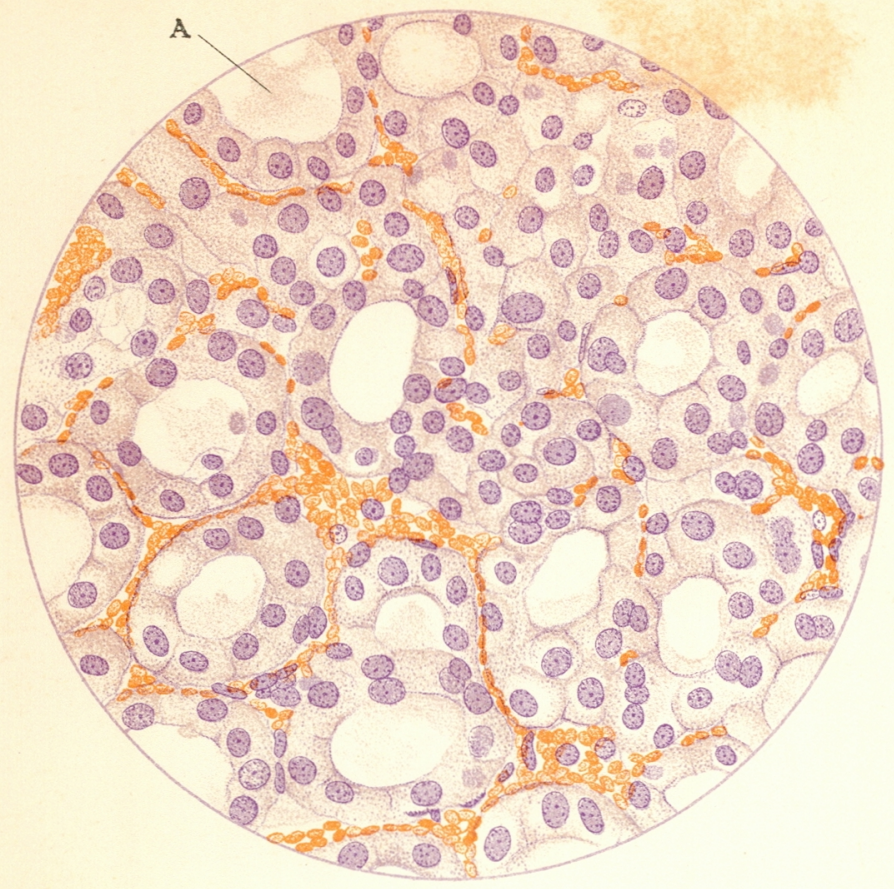

Fig. II.

$\rightarrow 0$

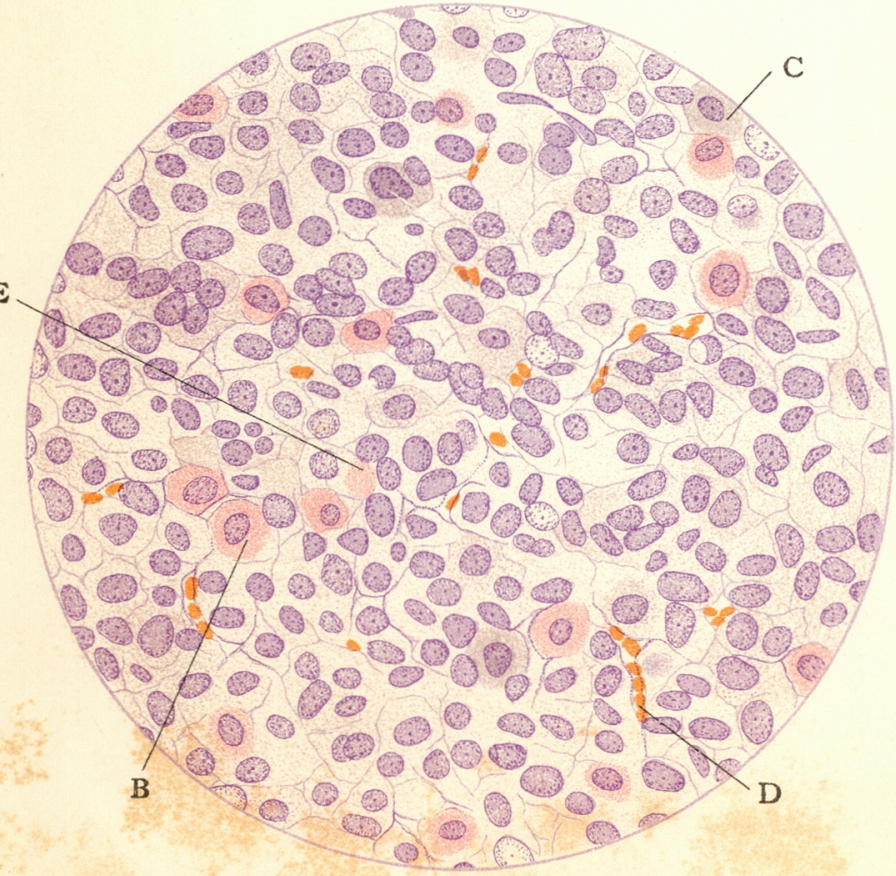


Fig. III.

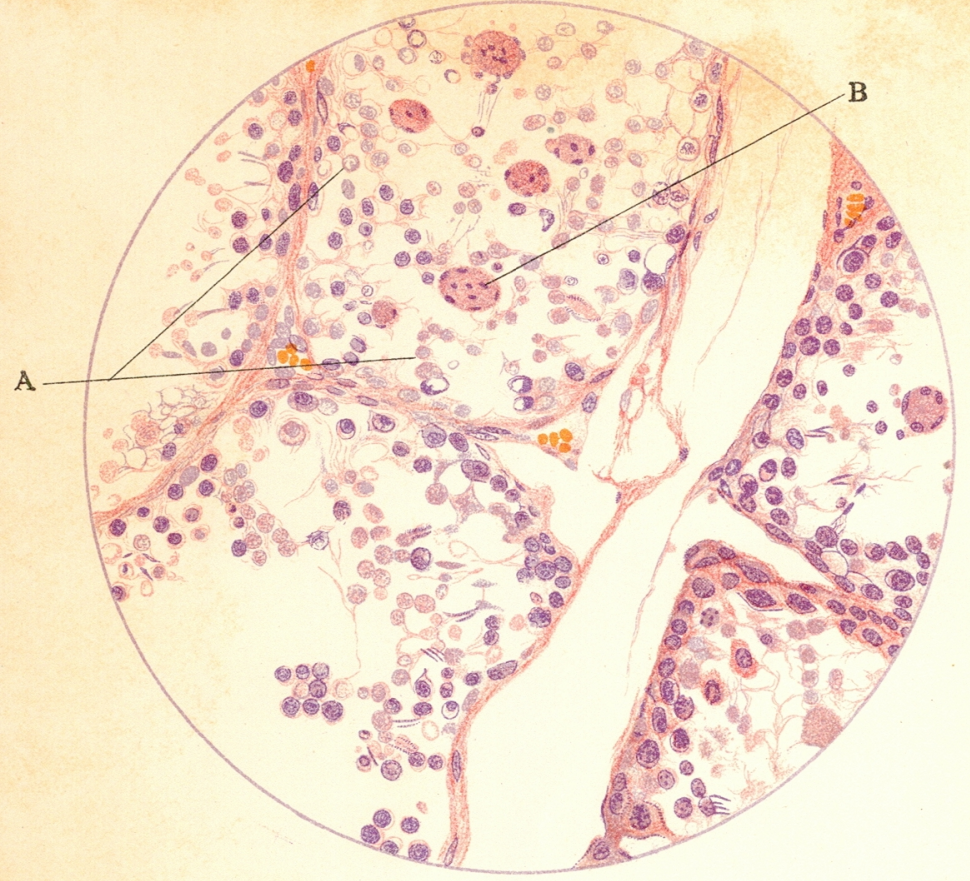

Fig. IV.

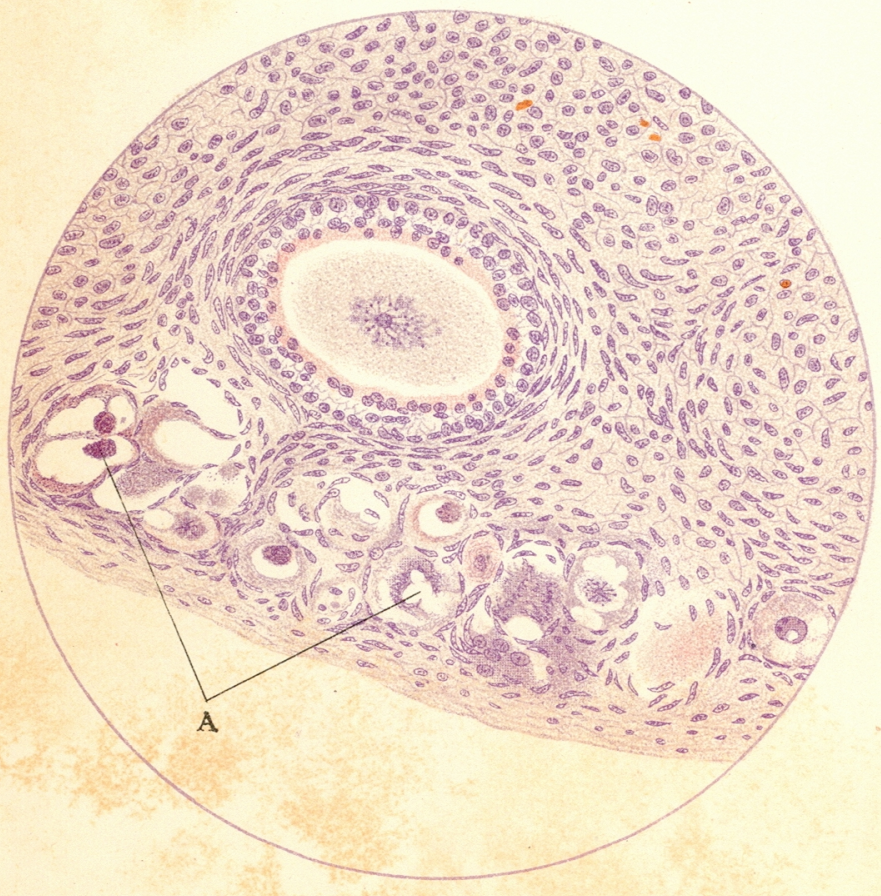


Im Blutserum und in den oben erwähnten Organen neigen der Reststickstoff und Harnsstoffgehalt im allgemeinen zur Verminderung, besonders in der Leber und der Niere.

3) Nach der gleichzeitigen Exstirpation der Milz und der Schilddrüse ist der lösliche Stickstoffgehalt im allgemeinen beinahe normal.

4) Die oben geschilderten Resultate, wenigstens in der ersten Woche nach der Operation, sprechen dafür, dass die durch die Thyreoidektomie und die durch die Splenektomie verursachten Wirkungen im allgemeinen entgegengesetzte sind. Vielleicht wirken die Milz und die Schilddrüse auf den Eiweissstoff wechsel antagonistisch zueinander, und zwar in dem Sinne, dass die Schilddrüse einen fördernden und die Milz einen hemmenden oder sparenden Einfluss darauf ausübt.

Zur Verminderung des löslichen Stickstoffgehalts in der 2. oder 3. Woche nach der Splenektomie kommt es wahrscheinlich dadurch, dass sehr rasch eine starke Kompensationsleistung der anderen Organe eintritt.

(Autoreferat)

\section{Ueber den Einfluss von Sake (japanischer Wein) auf die Gewebe der endokrinen Organe.}

$$
\text { Von }
$$

Dr. T. Suematsu.

(Aus der I. med. Klinik der Kaiserlichen Universität zu Kyoto, Japan. Direktor. Prof. Dr. K. Tsuji.)

Von Kaninchen und weissen Ratten, welche pro $\mathrm{I} 00 \mathrm{~g}$ Tier 3,5 bzw. 7 Wochen lang täglich $0,4 \mathrm{ccm}$ Sake von I3,08 Gewichtsprozent Alkohol per os erhalten hatten, wurden die innersekretorischen Organe histologisch untersucht. Diese Tiere 
nahmen im allg. an Körpergewicht etwas ab im Vergleich mit den Kontrolltieren, während sich das Gewicht der einzelnen endokrinen Organe bei den Tierarten gan $\boldsymbol{x}$ verschieden verhielt. Bei den Kaninchen: Schilddrüse und Thymus nahmen an Gewicht zu, Nebenniere, Hoden u. Ovarium ab, Hypophyse unbestimmt. Bei den Ratten: Hypophyse u. Ovarium nahmen an Gewicht ab, Thymus, Nebenniere u. Hoden zu, die Schilddrüse anfangs ab, später zu.

Die Resultate sind die folgenden:

Schilddrüse :

Es liessen sich pathologisch-morphologisch rundliche und kleine Follikel, Abnahme bzw. Verschwinden der Kolloidsubstanz, Hypertrophie und Hyperplasie der Follikelepithelien und Hyperämie der Kapillargefässe feststellen, was alles auf eine gesteigerte Funktion des betreffenden Organes hinweist.

Hypophyse.

Im Vorderlappen Vergrösserung und Vermehrung der Hauptzellen, Verminderung der eosinophilen, relative Abnahme der basophilen Zellen und Mangel an Gefässen, alles Zeichen von Hypofunktion der Hypophyse. Im Mittel- und Hinterlappen waren keine Veränderungen zu beobachten.

Hoden.

Verminderung der Samentierchen, Abstossung und Vakuolenbildung der Epithelien der geraden Samenkanälchen. Schrumpfung bzw. Pyknose der Kerne (bei Kaninchen sogar Auftreten von Riesenzellen) und Wucherung des gefässarmen Bindegewebes. Diese Degenerationserscheinungen kamen im Verlauf des Versuches immer deutlicher zum: Ausdruck.

Eierstock.

Vakuolisierung der Zellen, Karyolyse und Pyknose, Kalkablagerung, Mangel an Gefässen. Je mehr Sake gegeben wurde, desto so deutlicher wurden diese Befunde. Bei den Kaninchen waren die Befunde hochgradiger als bei den weissen Ratten.

An Thymus, Pankreas und Nebenniere sah der Verfasser keine nennenswerten Veränderungen. (Autoreferat) 